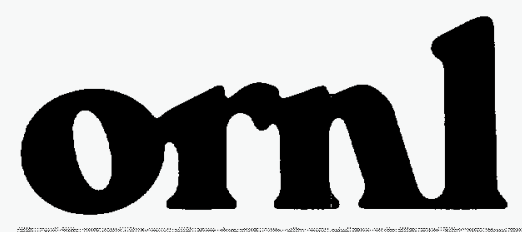

OAK RIDGE NATIONAL LABORATORY

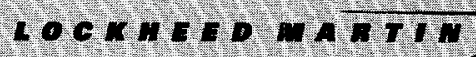

Development of NZP Ceramic Based "Cast-in Place" Diesel Engine Port Liners

R. Nagaswaran

S. Y. Limaye

RECEIVED

SEP 241996

OSTI

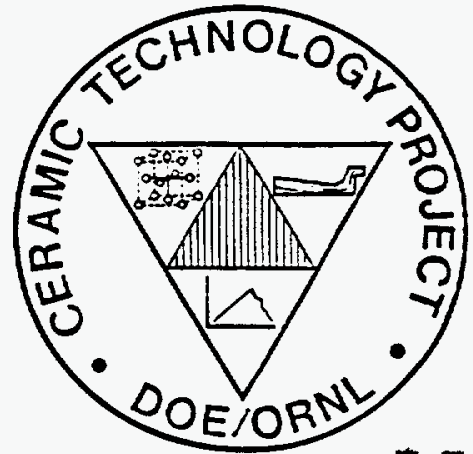

IMW WeE AHOPERTEO BY

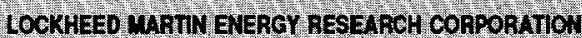
HOWHEWH WOSTHE:

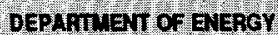


This report has been reproduced directly from the best available copy.

Available to DOE and DOE contractors from the Office of Scientific and Techntcal Information, P.O. Box 62, Oak Ridge, TN 37831; prices available from (423) 576-8401, FTS 626-8401.

Avaliable to the public from the National Technical Information Service, U.S. Department of Commerce, 5285 Port Royel Rd., Springfield, VA 22161.

This report was prepared as an account of work sponsored by an agency of the United States Government. Neither the United States Government nor any agency thereof, nor any of their employees, makes any warranty, express or implied, or assumes any legal liability or. responsibility for the accuracy, completeness, or usefulness of any information, apparatus, product, or process disclosed, or represents that its use would not intringe privately owned rights. Reference herein to any specific commercial product, process, or service by trade name, trademark, manufacturer, or otherwise, does not necessarily constitute or imply its endorsement, recommendation, or favoring by the United States Government or any agency thereot. The views and opinions of authors expressed herein do not necessarily state or reflect those of the United States Government or any agency thereof. 


\title{
DEVELOPMENT OF NZP CERAMIC BASED "CAST-IN-PLACE" DIESEL ENGINE PORT LINERS
}

\author{
R. Nagaswaran
}

S. Y. Limaye

Date Published: February 1996

Prepared by LoTEC, Inc.

1840 West Parkway Boulevard

West Valley City, Utah 84119

\author{
Funded by \\ U.S. Department of Energy \\ Assistant Secretary for Energy Efficiency and Renewable Energy \\ Office of Transportation Technologies \\ Propulsion System Materials Program \\ EE 5105000
}

for

OAK RIDGE NATIONAL LABORATORY

Oak Ridge, Tennessee 37831-6285

managed by

LOCKHEED MARTIN ENERGY RESEARCH CORPORATION

for the

U.S. DEPARTMENT OF ENERGY under Contract DE-AC05-96OR22464 



\section{DISCLAIMER}

This report was prepared as an account of work sponsored by an agency of the United States Government. Neither the United States Government nor any agency thereof, nor any of their employees, makes any warranty, express or implied, or assumes any legal liability or responsibility for the accuracy, completeness, or usefulness of any information, apparatus, product, or process disclosed, or represents that its use would not infringe privately owned rights. Reference herein to any specific commercial product, process, or service by trade name, trademark, manufacturer, or otherwise does not necessarily constitute or imply its endorsement, recommendation, or favoring by the United States Government or any agency thereof. The views and opinions of authors expressed herein do not necessarily state or reflect those of the United States Government or any agency thereof. 


\section{DISCLAIMER}

Portions of this document may be illegible in electronic image products. Images are produced from the best available original document. 



\section{TABLE OF CONTENTS}

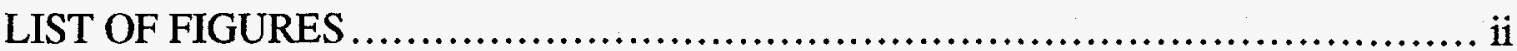

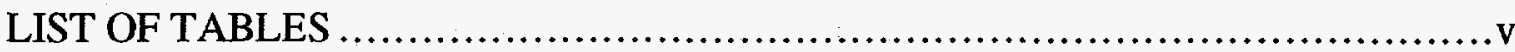

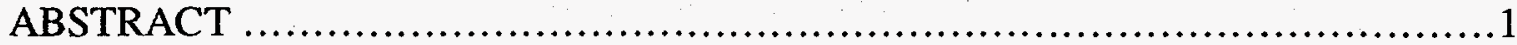

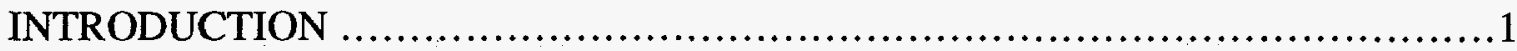

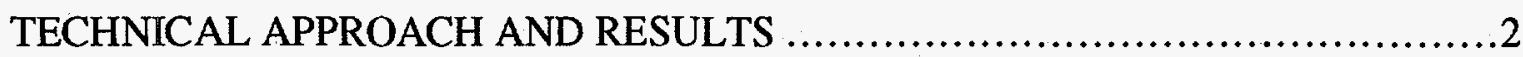

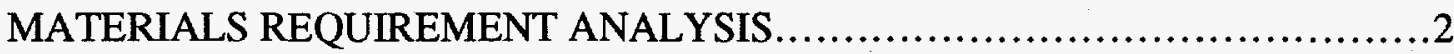

MATERIALS PROCESSING AND PROCESS OPTIMIZATION .................9

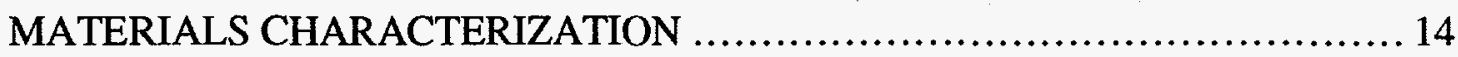

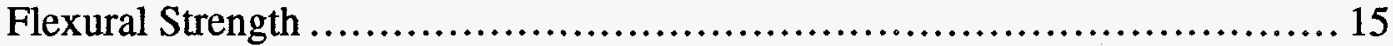

Thermal Diffusivity ........................................................ 17

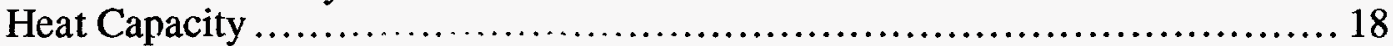

Thermal Conductivity ..................................................... 19

Thermal Expansion........................................................ 19

Microstructural Considerations ......................................... 29

Environmental Effects (Moisture, Temperature) .......................... 36

Thermal Stability ................................................................ 39

Thermal Shock Resistance ...................................................... 40

High Temperature Elastic Modulus ........................................ 43

MATERIALS AND PROCESSES' DEVELOPMENT.......................... 44

Molten Metal Casting Trials............................................... 45

Pressure Slip Casting .......................................................... 48

Gel Casting ................................................................. 50

Ultrasonic NDE Technique................................................... 51

New NZP materials........................................................ 52

Microcracking Investigation by Acoustic Emission .......................... 53

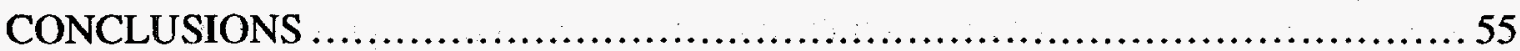

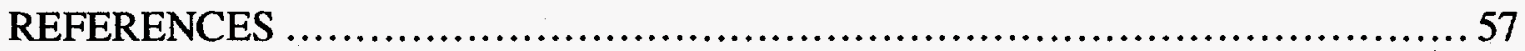

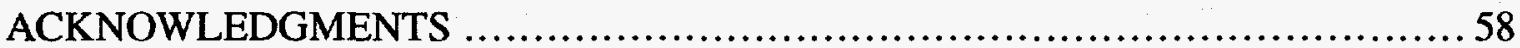




\section{LIST OF FIGURES}

Figure 1. Dimensions of cer:

Figure 2. Temperature distr: process. (Results

Figure 3. Schematic of set-lit

Figure 4. Detailed sectional

Figure 5. Metal cooling cur

Figure 6. FEM calculated (c various thermoco

Figure 7. Flow chart detaili

Figure 8. XRD traces of BS

Figure 9. XRD pattern of $B^{r}$

Figure 10. Effect of milling calcined at $1200^{\mathrm{C}}$

Figure 11. Flexure strength

(b) CSX compos

Figure 12. Thermal Conduct

Figure 13. Thermal expansion composition.

tubes for molten metal casting trials. 5

1 as a function of time during molten metal casting obtained using TOPAZ2D software package)..........6

multen metai casting trials. ..........................7

of the set-up for Metal Casting trials. .................7

snerated by finite element analysis (FEA). .............8

s) vs. actual temperatures as a function of time for cations. .......................................... 8

os involved in the fabrication of NZP green bodies. ....9 owders calcined at (a) $1150^{\circ} \mathrm{C}$ and (b) $1250^{\circ} \mathrm{C}$...... 11 powder calcined at $1200^{\circ} \mathrm{C}$ showing only NZP phase. 12 and conditions on surface area of BS- 25 powders 4 hours. 13

umber of thermal cycles to $1250^{\circ} \mathrm{C}$ for (a) BSX and 16

of BS-25 composition as a function of temperature... 20

easurements of two different samples of BS-0 20

Figure 14. Thermal expansion measurements of two different samples of BS-25 composition.

Figure 15. Thermal expansion measurements of two different samples of BS-50 composition.

Figure 16. Thermal expansion measurements of two different samples of CS-25 composition.

Figure 17. Thermal expansion measurements of two different samples of CS-50 composition.

Figure 18. Effect of thermal cycling on the bulk linear thermal expansion of BS-0 material.

Figure 19. Effect of thermal cycling on the bulk linear thermal expansion of BS-17 material.

Figure 20. Effect of thermal cycling on the bulk linear thermal expansion of BS-25 material.

Figure 21. Effect of thermal cycling on the bulk linear thermal expansion of BS-37.5 material. 
Figure 22. Effect of thermal cycling on the bulk linear thermal expansion of BS-50 material.

Figure 23. Thermal expansion anisotropy and axial expansion of BSX as a function of composition (silicon content)...

Figure 24. Effect of thermal cycling on the bulk linear thermal expansion of CS-25 material.

Figure 25. Effect of thermal cycling on the bulk linear thermal expansion of CS-37.5 material.

Figure 26. Effect of thermal cycling on the bulk linear thermal expansion of CS-50 material.

Figure 27. Room temperature expansion of CS-25 material in the presence of air. .....28

Figure 28. SEM fracture surface microstructures of (a) as-sintered and (b) thermally cycled $\left(250\right.$ cycles to $\left.1250^{\circ} \mathrm{C}\right) \mathrm{BS}-0$ specimens.

Figure 29. SEM fracture surface microstructures of (a) as-sintered and (b) thermally cycled $\left(250\right.$ cycles to $\left.1250^{\circ} \mathrm{C}\right) \mathrm{BS}-25$ specimens.

Figure 30. SEM fracture surface microstructures of (a) as-sintered and (b) thermally cycled $\left(250\right.$ cycles to $\left.1250^{\circ} \mathrm{C}\right) \mathrm{BS}-50$ specimens.

Figure 31. SEM fracture surface microstructures of (a) as-sintered and (b) thermally cycled $\left(250\right.$ cycles to $\left.1250^{\circ} \mathrm{C}\right) \mathrm{CS}-25$ specimens.

Figure 32. SEM fracture surface microstructures of (a) as-sintered and (b) thermally cycled $\left(250\right.$ cycles to $\left.1250^{\circ} \mathrm{C}\right) \mathrm{CS}-50$ specimens.

Figure 33. Moisture-assisted microcracking of anisotropic composition CS-25....... 37

Figure 34. Environmental Effect on Room Temperature Expansion of various NZP compositions......................................................... 38

Figure 35. Environmental Effect on Room Temperature Expansion of BS-0.......... 38

Figure 36. Powder X-ray diffraction patterns of "As-Sintered" and "Moisture-treated" CS-25 material...................................................... 40

Figure 37. Normalized weight loss as a function of cycles to $1250^{\circ} \mathrm{C}$ for the (a) BSX

(b) and CSX compositions.

Figure 38. Maximum survivable thermal shock temperature for BSX compositions. ... 42

Figure 39. Residual flexure strengths of cyclically thermal shocked BSX specimens. .. 43

Figure 40. Elastic modulus of BS 25 as a function of temperature. 44

Figure 41. X-Ray computer tomography picture of the metal-ceramic composite tube with compliant layer in between.

Figure 42. X-Ray computer tomography picture of the metal-ceramic composite tube showing crack (arrow) in the ceramic.

Figure 43. Schematic of set-up for Pressure Slip Casting (PSC) process.

Figure 44. Effect of applied pressure on the wall thickness of cast body.

Figure 45. Effect of slip casting time on wall thickness of the cast body. 50 
Figure 46. Schematic layout of the sequence involved in gel-casting procedure. ...... 51

Figure 47. Schematic diagram of the ultrasonic NDE set-up used for flaw detection.... 52

Figure 48. XRD phase content data of (a) C'SX, (b) S'SX and (c) C'S'SX material

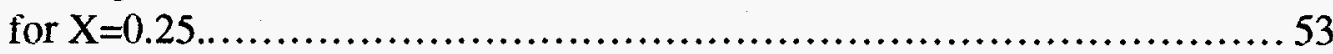




\section{LIST OF TABLES}

Table 1. Preliminary data used for developing the thermal analysis model...............4

Table 2. Mechanical stresses as a function of time and radial distance during metal casting with NZP ceramic in place........................................6

Table 3. Results of Test Matrix for Evaluating and Improving Calcination Process. .... 12

Table 4. Summary of the room temperature flexural strengths of as-sintered and thermally-cycled $\left(1250^{\circ} \mathrm{C}\right) \mathrm{BSX}$ and CSX materials....................... 17

Table 5. Thermal Diffusivity of various BSX and CSX Compositions. ................ 18

Table 6. Thermal Conductivity ( $\mathrm{K}$ ) of BS-25 material as a function of temperature. ... 19

Table 7. Planned tests for improving NZP-ceramic survivability during the metal casting process 


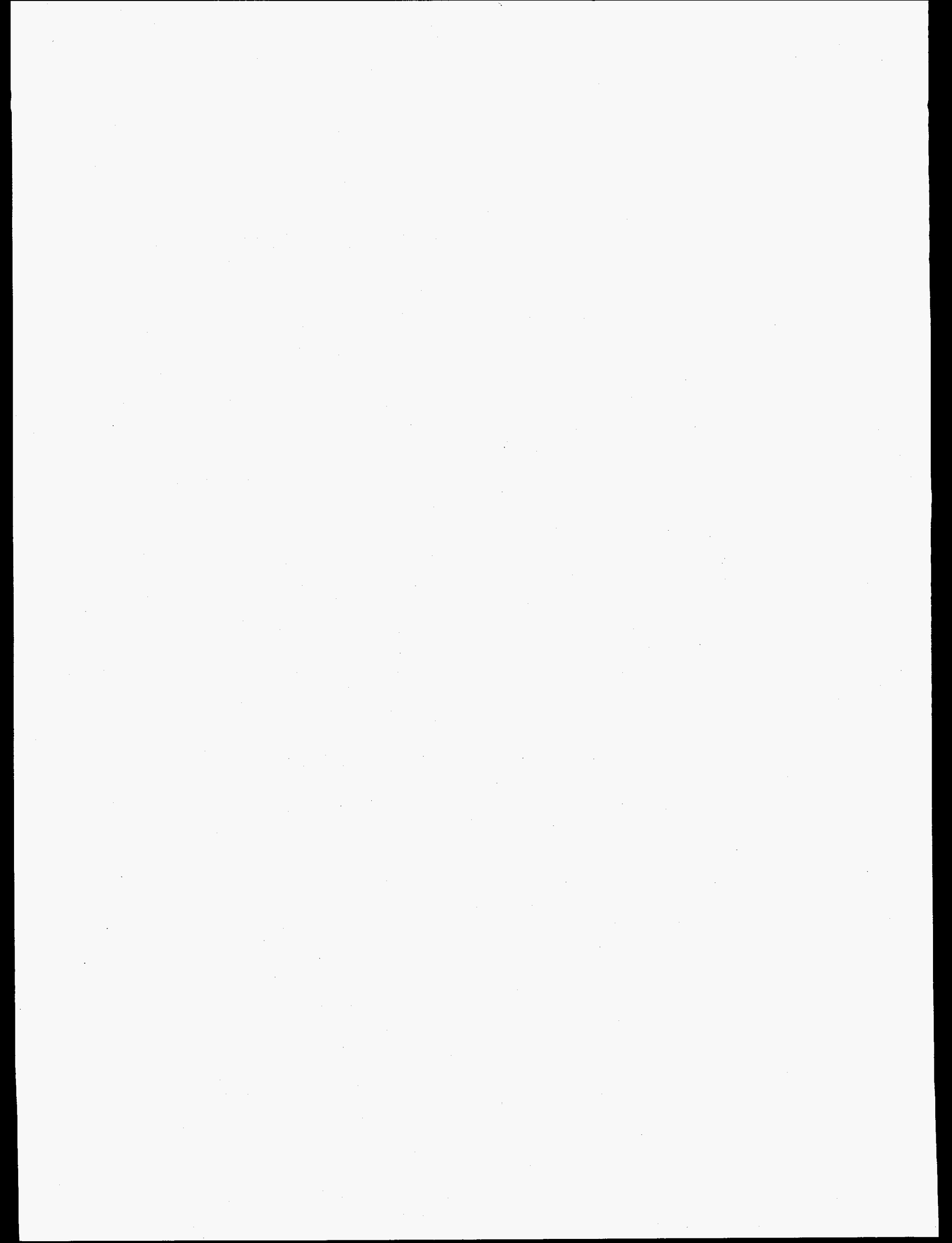




\section{ABSTRACT}

BSX $\left(\mathrm{Ba}_{1+\mathrm{x}} \mathrm{Zr}_{4} \mathrm{P}_{6-2 \mathrm{x}} \mathrm{Si}_{2 \mathrm{x}} \mathrm{O}_{24}\right)$ and $\mathrm{CSX}\left(\mathrm{Ca}_{1-\mathrm{x}} \mathrm{Sr}_{\mathrm{x}} \mathrm{Zr}_{4} \mathrm{P}_{6} \mathrm{O}_{24}\right)$ type NZP ceramics were fabricated and characterized for: (i) thermal properties viz., thermal conductivity, thermal expansion, thermal stability and thermal shock resistance; (ii) mechanical properties viz., flexure strength and elastic modulus; and (iii) microstructures. Results of these tests and analysis indicated that the BS- 25 ( $x=0.25$ in BSX) and CS-50 ( $x=0.50$ in CSX) ceramics had the most desirable properties for casting metal with ceramic in place. Finite element analysis (FEA) of metal casting (with ceramic in place) was conducted to analyze thermomechanical stresses generated and determine material property requirements. Actual metal casting trials were also conducted to verify the results of finite element analysis. In initial trials, the ceramic cracked because of the large thermal expansion mismatch (hoop) stresses (predicted by FEA also). A process for introduction of a compliant layer between the metal and ceramic to alleviate such destructive stresses was developed. The compliant layer was successful in preventing cracking of either the ceramic or the metal. In addition to these achievements, pressure slip casting and gelcasting processes for fabrication of NZP components; and acoustic emission and ultrasonics-based NDE techniques for detection of microcracks and internal flaws, respectively, were successfully developed.

\section{INTRODUCTION}

Low thermal expansion, good thermal shock resistance, high melting temperature and thermal stability are attractive properties for numerous applications (such as in diesel-engine port liners) involving ceramics. In general, NZP ceramics have low thermal expansion coefficients but their thermal shock properties and melting temperatures are highly composition dependent. Also, it has been recognized that low thermal expansion, per se, is not so beneficial if it is accompanied by anisotropy ${ }^{14}$. However, because of their unique crystal structure specific NZP ceramic compositions could be tailored to have all uf thi riquisiste properties including very low anisotropy. This potential gives NZP ceramics a significant edge over conventional low expansion materials such as cordierite, mullite, aluminum titanate, LAS and fused silica. 
Of the numerous NZP materials $\mathrm{i}$ stigated thus far, the BSX $\left(\mathrm{Ba}_{1+\mathrm{x}} \mathrm{Zr}_{4} \mathrm{P}_{6}\right.$ $\left.{ }_{2 \mathrm{x}} \mathrm{Si}_{2 \mathrm{x}} \mathrm{O}_{24}\right)$ and $\mathrm{CSX}\left(\mathrm{Ca}_{1-\mathrm{x}} \mathrm{Sr}_{\mathrm{x}} \mathrm{Zr}_{4} \mathrm{P}_{6} \mathrm{O}_{24}\right)$ type of materials have both ultra-low thermal expansions ${ }^{4-5}$ and high melting temperature. Even so, evaluation of their thermal expansion anisotropy, thermal shock resistance and mechanical properties as a function of composition is important from an applications standpoint. For instance, in the diesel engine port-liner application mechanical vibrations are an important issue in addition to thermal loads associated with the high temperature environment. The need to integrate or bond two widely different materials such as ceramic and metal in the port further complicates material requirements.

The above discussed were the motivating factors for Phase I research; the broad purpose of which was to identify NZP materials with optimum properties such as would permit fabrication of "cast-in-place" diesel engine port liners. As an extension of this, exploration of alternate NZP type maieriais and fabrication and characterization processes will also be conducted. The overall objective of this Phase I research program was to develop sodium-zirconium-phosphate (NZP) ceramic based "cast-in-place" diesel engine port liners. Specific objectives were: (1) Materials requirement analysis, (2) Successful demonstration of metal casting around the ceramic, (3) Cost-effective process development, and (4) Development of high temperature database (stability, thermal cycling, thermal shock etc.).

\section{TECHNICAL APPROACH AND RESULTS}

Following the initial group meeting held at Chicago in October 1992 the work plan for Phase I research, in the form of a series of tasks, was formalized. The technical approach used to fulfill these tasks and results obtained have been discussed in the following.

\section{MATERIALS REQUIREMENT ANALYSIS}

A preliminary finite element analysis (FEA) was carried out to evaluate the stresses involved in the metal casting process. A set of properties based on prior information was chosen for the NZP ceramic, metal and the sand used in metal casting process. Table 1 
summarizes the properties that were chosen for this finite element stress analysis. Two different casting configurations were considered for this finite element analysis; a straight tube and an L-shaped tube as shown in Figure 1. Instead of using commercially available FEA software packages such as ANSYS, a set of public domain software packages called INGRID (for grid generation), TUPAZ2D ( tor thermal analysis) and NIKE2D (for stress analysis) were used. These software packages are less expensive and provide similar results. In order to verify the functionality of these software packages, a standard "high confidence" problem was analyzed using these software packages and the solutions were found to be satisfactory. The results of the preliminary FEA are shown in Figure 2 and Table II. These results show that the NZP ceramic is subjected to large compressive hoop stresses along the radial directions.

In this work, metal casting trials were used to verify the finite element (FEA) results and further refine the FEA model. Initial trials were designed to measure actual temperatures during casting for comparison with the theoretical temperature profiles generated using the finite element modeling (FEA). Figures 3 and 4 depict the details of the set-up used for metal casting trials. Molten metal was cast around the ceramic tubes (BS-25) in a sand mold. Four tubes ( $2 "$ dia, 6" long) were used for these trials. A series of four thermocouples were buried at various locations to obtain temperature profiles during the actual casting trial. The temperature was recorded using a standard A/D dataacquisition board. This data was then compared with the thermal gradient patterns generated by FEA (as shown in Figure 2).

The results of the temperature measurement trials show that the initial finite element model approximates the actual casting trials. This is evident from Figures 5 and 6. Based on the results of the first metal casting trials, further modifications to the FEA model were made to initiate iterative refinement of the FEA model. Eventually, this model would be so refined as to perform a parametric study of the effects of various materials' properties on thermal stresses. Later in this Phase I program, NZP ceramic tubes were fabricated for further metal casting trials to verify the results of the analytical model. Prior to this, a detailed characterization of the material properties of the various NZP ceramics had to be conducted to enable selection of a few ceramics with suitable properties. The fabrication and characterization methods used to produce baseline NZP ceramic materials and assess their properties, respectively, are described in the following sections. 
Table 1. Preliminary data used for developing the thermal analysis model.

\begin{tabular}{|c|c|c|c|}
\hline $\begin{array}{c}\text { Material Properties and Model Inputs } \\
\text { (Presented in the MKS, cgs units system) }\end{array}$ & $\mathbf{N Z P}$ & $\begin{array}{l}\text { Gray Cast } \\
\text { Iron } \\
\end{array}$ & Sand \\
\hline \multicolumn{4}{|l|}{ General Properties } \\
\hline Length $(\mathrm{cm})$ & 15 & 15 & 15 \\
\hline Thickness (cm) & 0.3 & 1 & 30 \\
\hline Density $\left(\mathrm{kg} / \mathrm{m}^{\wedge \wedge} 3\right)$ & $3200-3650$ & 7000 & 1450 \\
\hline \multicolumn{4}{|l|}{ Mechanical Properties } \\
\hline Flexural Strength (MOR) (MPa) & $* * *$ & $* * *$ & *** \\
\hline $25 \mathrm{C}$ & 70 & **** & **** \\
\hline $1000 \mathrm{C}$ & 70 & $* * *$ & $* * *$ \\
\hline $1500 \mathrm{C}$ & 65 & $* * *$ & $* * *$ \\
\hline Young's Modulus $25 \mathrm{C}$ to $1000 \mathrm{C}$ (GPa) & 70 & **** & $* * *$ \\
\hline Fracture Toughness (MPa) & $1.5-2.0$ & $* * *$ & $* * *$ \\
\hline Ultimate Strength (MPa) & $* * *$ & $* * *$ & $* * *$ \\
\hline Tension & $30-90$ & 370 & $* * *$ \\
\hline Cumpression & $90-300$ & 830 & **** \\
\hline Shear & $* * *$ & 330 & $* * *$ \\
\hline Yield Strength (MPa) & $* * *$ & $* * *$ & $* * *$ \\
\hline Tension & $30-90$ & 250 & $* * *$ \\
\hline Shear & $* * *$ & 165 & *** \\
\hline Allowable Stresses (kPa) & **** & $* * *$ & $* * *$ \\
\hline Tension or Compression & $* * *$ & 165475 & $* * *$ \\
\hline $\begin{array}{r}\text { Shear } \\
\end{array}$ & *** & 99975 & **** \\
\hline Elastic Modulii (GPa) & $* * *$ & $* * *$ & $* * *$ \\
\hline Tension or Compression & $35-100$ & 172 & **** \\
\hline Shear & $* * *$ & 83 & $* * *$ \\
\hline Poisson Ratio & 0.24 & 0.28 & \\
\hline \multicolumn{4}{|l|}{ Thermal Properties } \\
\hline Thermal Conductivity (W/m K) & 1 & 41.9 & 1.26 \\
\hline \multicolumn{4}{|l|}{$\begin{array}{l}\text { Thermal Conductivity as a f(Temp) }(\mathrm{W} / \mathrm{m} \mathrm{K}) \\
\text { (Sand) } 0.6606-2.084 \mathrm{E}-4 \mathrm{~T}+7.741 \mathrm{E}-7 \mathrm{~T}^{\wedge \wedge} 2\end{array}$} \\
\hline Specific Heat (J/kg K) & $* * *$ & **** & $* * *$ \\
\hline Ambient & 460 & 628 & 838 \\
\hline $473 \mathrm{~K}$ & $* * *$ & **** & 975.7 \\
\hline $673 \mathrm{~K}$ & $* * *$ & $* * *$ & 1092.9 \\
\hline $873 \mathrm{~K}$ & $* * *$ & $* * *$ & 1151.5 \\
\hline $1073 \mathrm{~K}$ & $* * *$ & $* * *$ & 1159.9 \\
\hline $1273 \mathrm{~K}$ & $* * *$ & $* * *$ & 1176.7 \\
\hline Thermal Diffusivity $\left(\mathrm{m}^{\wedge \wedge} 2 / \mathrm{sec}\right)$ & $6.00 \mathrm{E}-07$ & $9.50 \mathrm{E}-06$ & $9.10 \mathrm{E}-07$ \\
\hline Coeff. of Thermal Expansion (1/C) (NZP 5 - $6 \mathrm{ppm})$ & $1.00 \mathrm{E}-06$ & $1.21 \mathrm{E}-05$ & $* * *$ \\
\hline $\begin{array}{l}\text { Heat Transfer Coefficient at Interface }\left(\mathrm{W} / \mathrm{m}^{\wedge} 2 \mathrm{~K}\right) \\
\text { mold/outside air }=83.8\end{array}$ & $* * *$ & $* * *$ & **** \\
\hline Ambient Temperature $\mathrm{K}$ & 293 & 293 & 293 \\
\hline Liquidus Temperature $\mathrm{K}$ & 2173 & 1573 & $* * *$ \\
\hline Solidus Temperature K & 2073 & 1275 & $* * *$ \\
\hline Initial Temperature K & 293 & 1273 & 293 \\
\hline
\end{tabular}




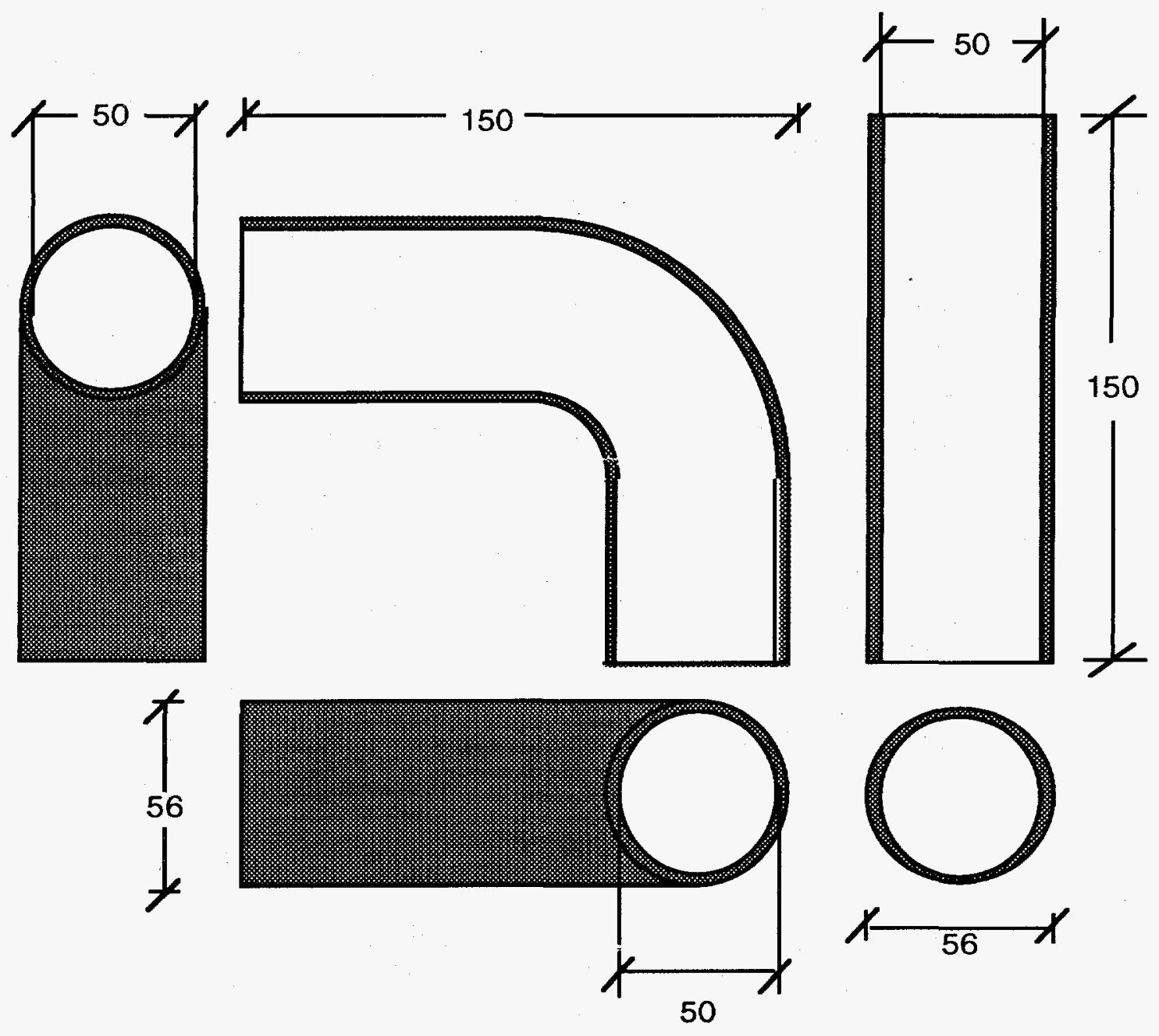

ALL DIMENSIONS ARE IN MILLIMETERS

Figure 1. Dimensions of ceramic tubes for molten metal casting trials. 


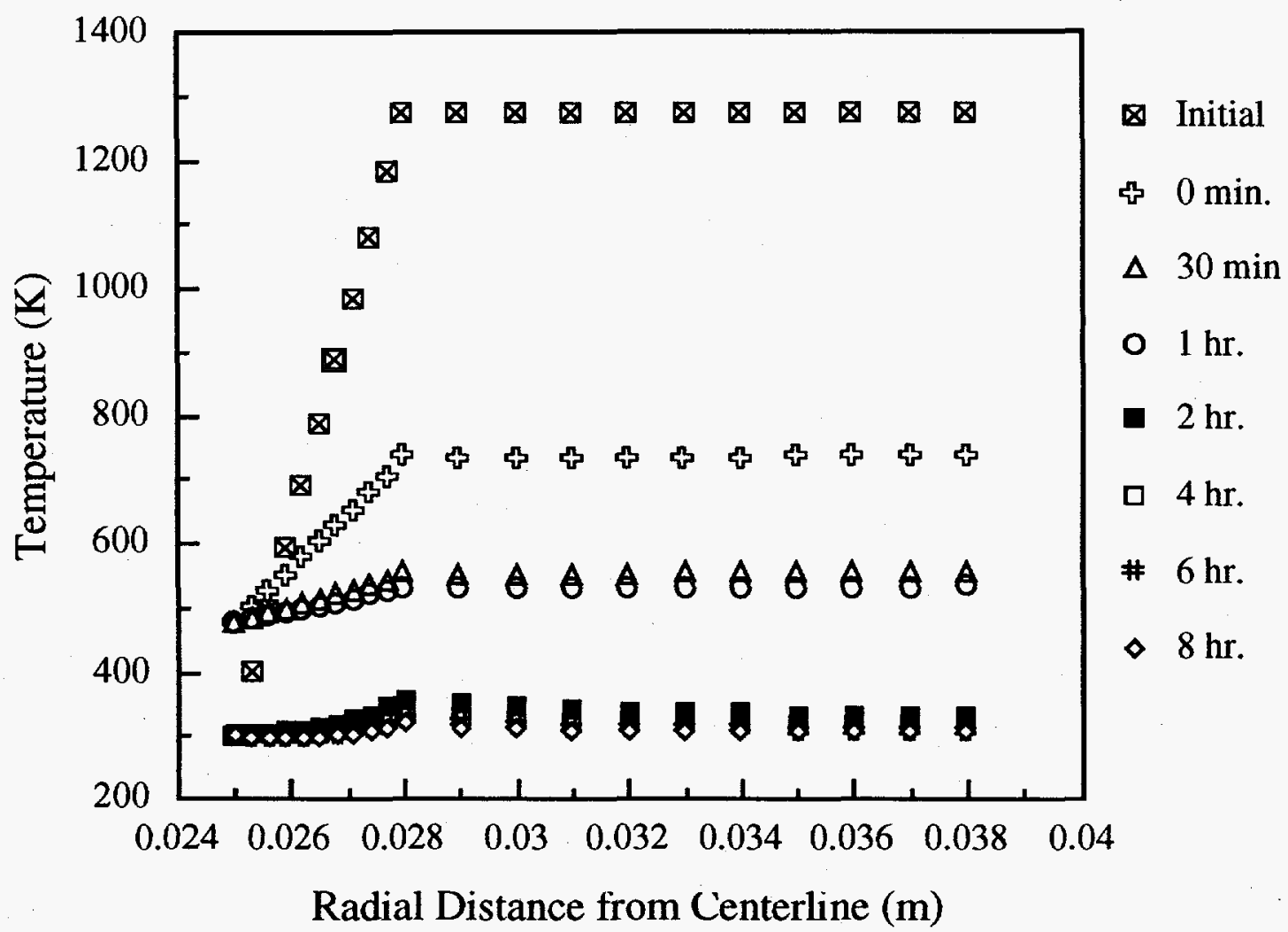

Figure 2. Temperature distribution as a function of time during molten metal casting process. (These results were obtained using TOPAZ2D software package.)

Table 2. Mechanical stresses as a function of time and radial distance during metal casting with NZP ceramic in place.

\begin{tabular}{|c|c|c|c|c|c|}
\hline \multirow{2}{*}{ Material } & Radial Dist. & \multicolumn{3}{|c|}{ Tangential Stresses (MPa) } & \multirow{2}{*}{$\begin{array}{c}\text { Type of } \\
\text { Stress }\end{array}$} \\
\cline { 3 - 5 } & $(\mathrm{m})$ & $30 \mathrm{~min}$. & $2 \mathrm{hr}$. & $4 \mathrm{hr}$. & \\
\hline NZP & 0.025 & -718.9 & -578.3 & -344.1 & Compressive \\
\hline NZP & 0.028 & -646.0 & -519.6 & -309.2 & Compressive \\
\hline Cast Iron & 0.028 & 246.1 & 198.0 & 117.8 & Tensile \\
\hline Cast Iron & 0.038 & 173.2 & 139.3 & 82.9 & Tensile \\
\hline
\end{tabular}




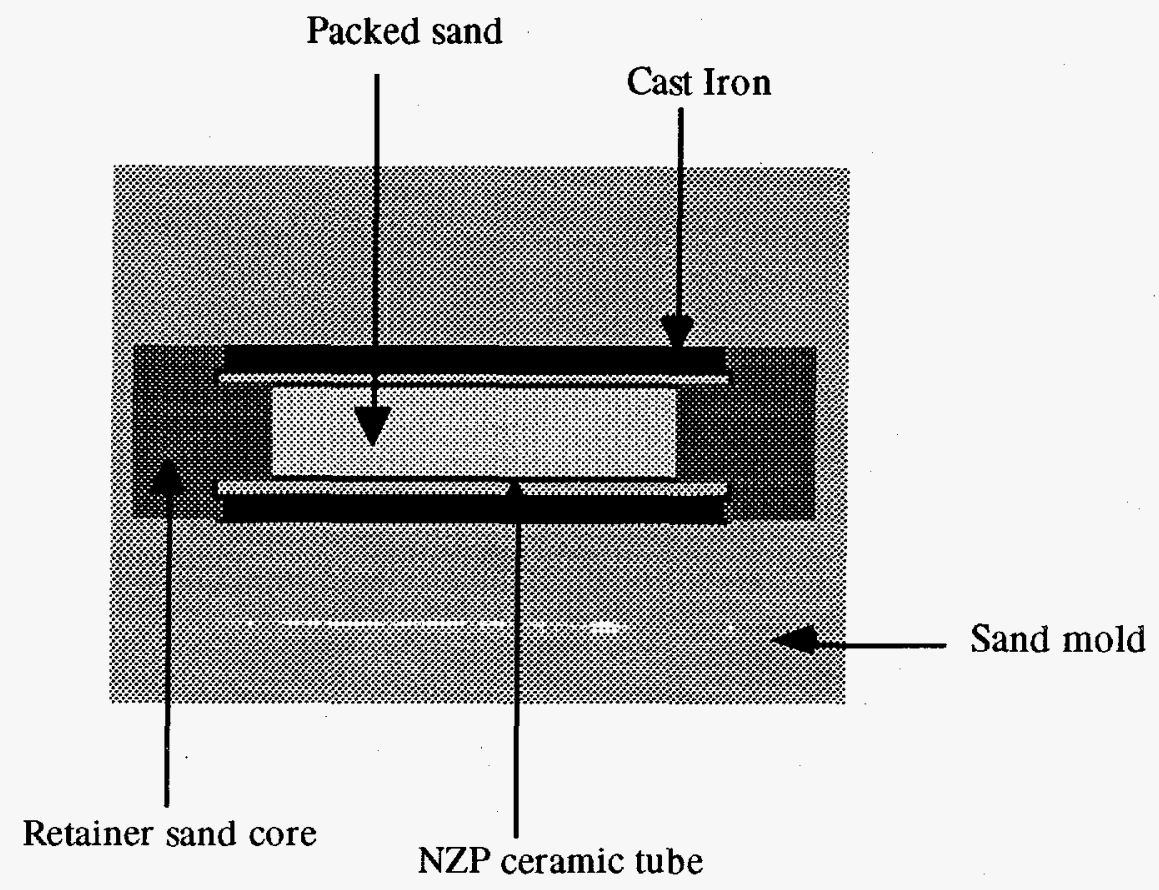

Figure 3. Schematic of set-up for molten metal casting trials.
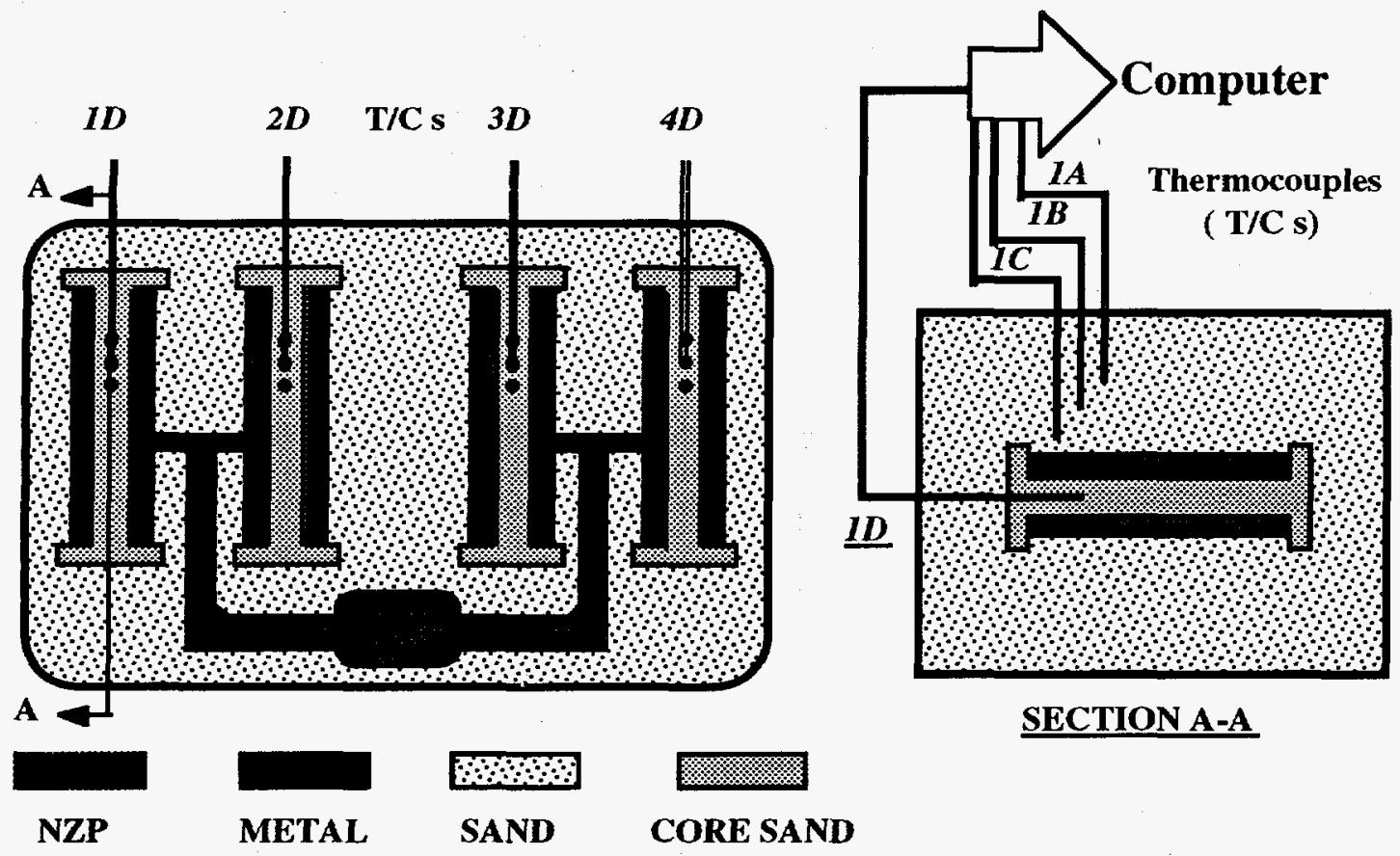

SECTION A-A

Figure 4. Detailed sectional view of the set-up for Metal Casting trials. 


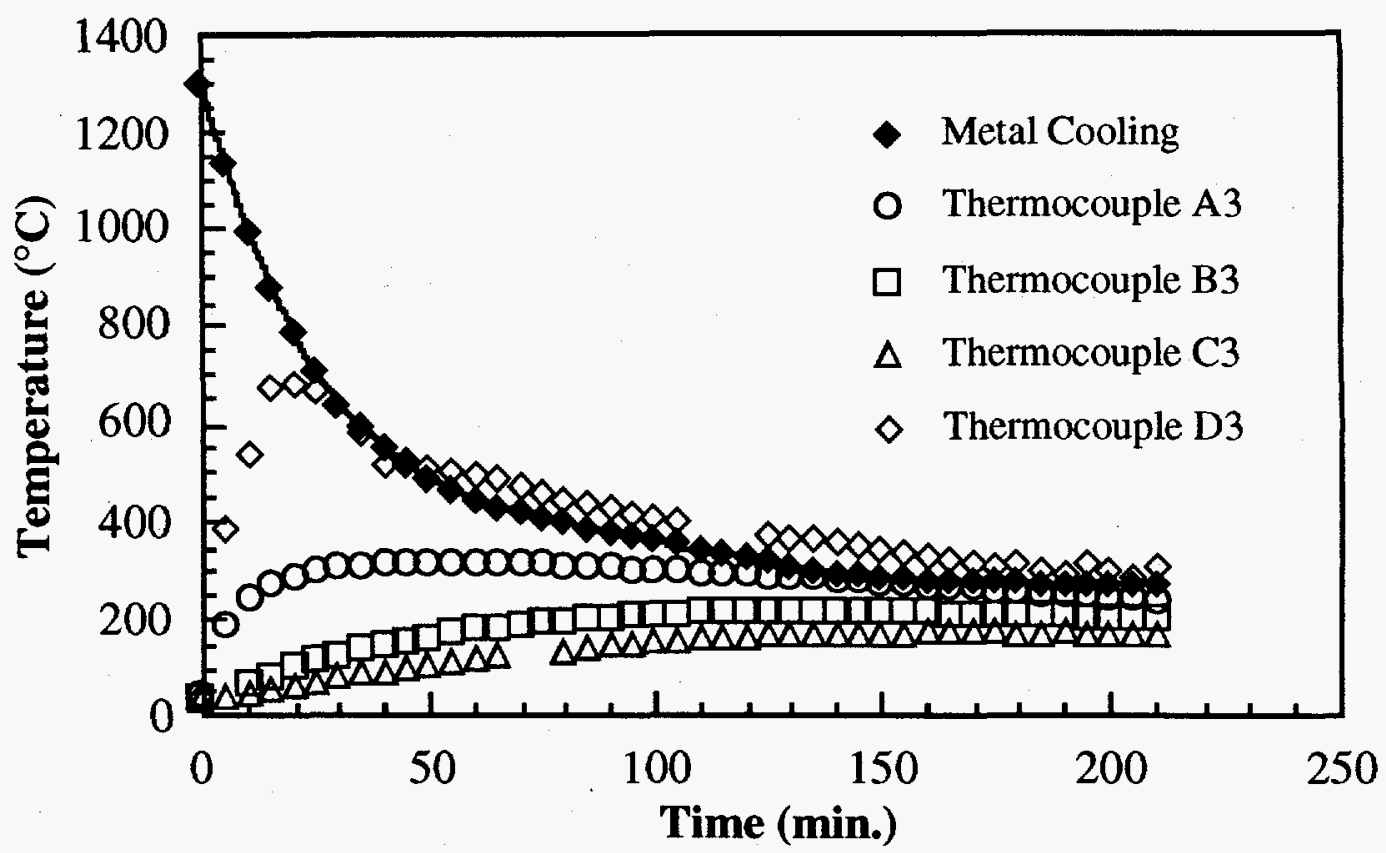

Figure 5. Metal cooling curves generated by finite element analysis (FEA).

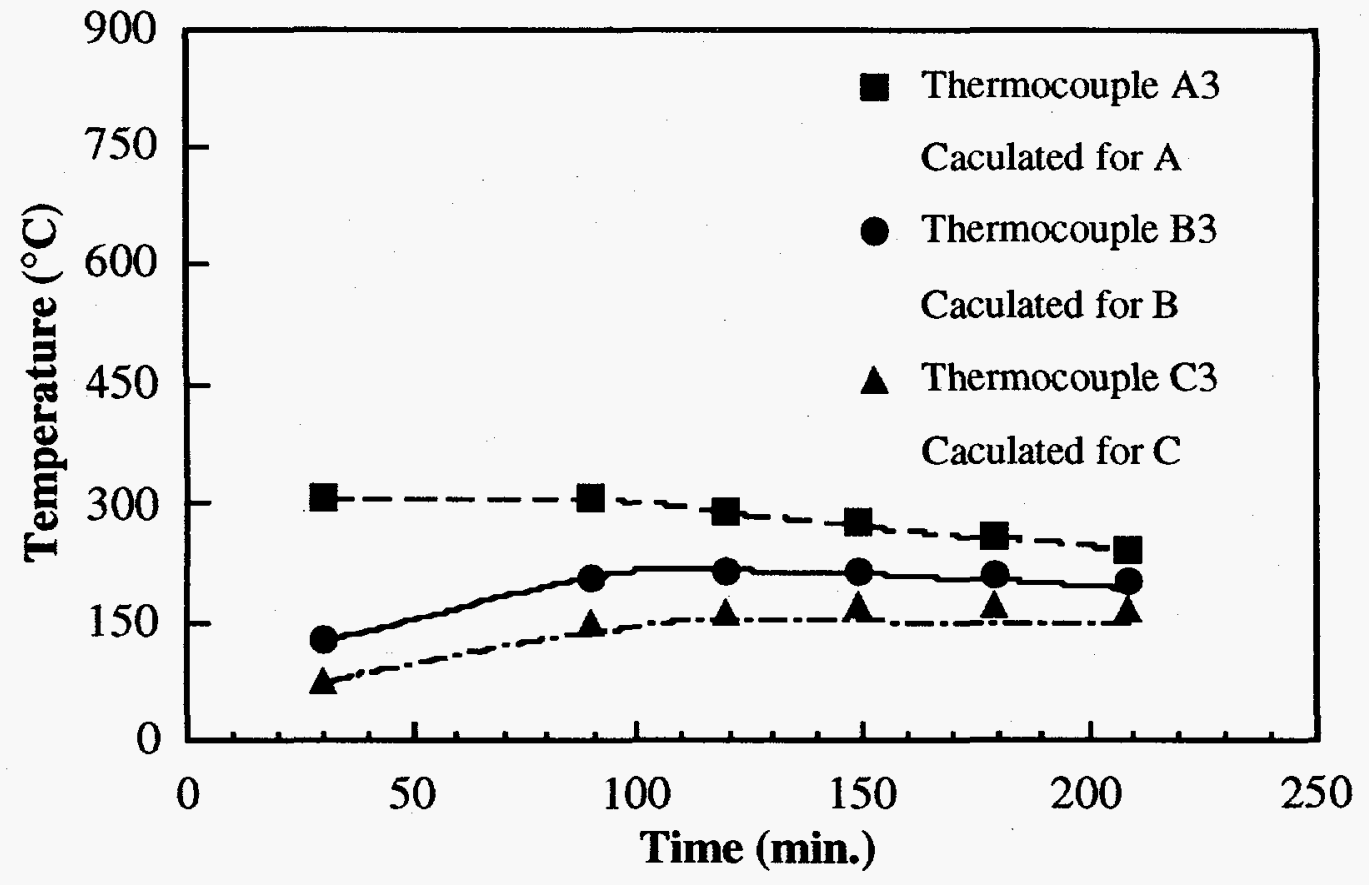

Figure 6. FEM calculated (curves) vs. actual temperatures as a function of time for various thermocouple locations. 


\section{MATERIALS PROCESSING AND PROCESS OPTIMIZATION}

Based on past experience, $\mathrm{BSX}\left(\mathrm{Ba}_{1+\mathrm{x}} \mathrm{Zr}_{4} \mathrm{P}_{6-2 x} \mathrm{Si}_{2 \mathrm{x}} \mathrm{O}_{24}\right)$ and $\mathrm{CSX}\left(\mathrm{Ca}_{1-}\right.$ ${ }_{x} \mathrm{Sr}_{x} \mathrm{Zr}_{4} \mathrm{P}_{6} \mathrm{O}_{24}$ ) series low thermal expansion NZP compositions with ' $\mathrm{x}$ ' varying as 0 , $0.17,0.25,0.375$ and 0.50 , and $0,0.25$ and 0.50 , respectively, were designated for processing and detailed evaluation of properties. Routine steps involved in the processing of these materials are shown in the schematic of Figure 7 here.

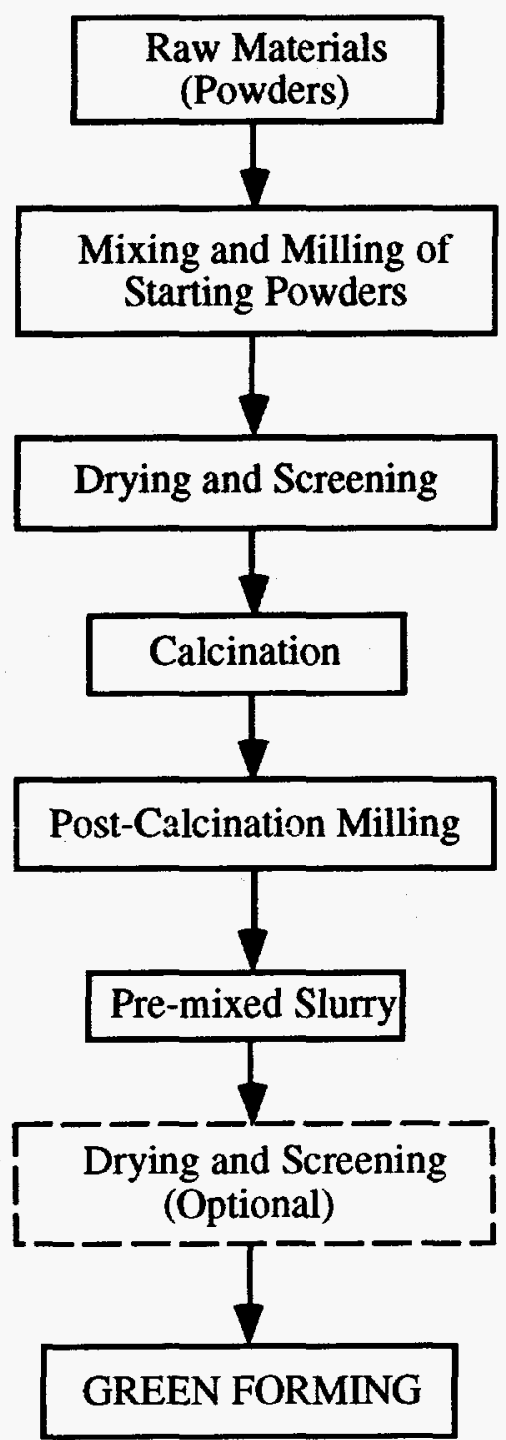

Figure 7. Flow chart detailing steps involved in the fabrication of NZP green bodies. 
Large $(20 \mathrm{~kg}$ ) batches of the powders were synthesized using the routine oxide batch mixing process. The size of the batches was chosen so as to insure availability of enough material to perform all the required testing and evaluation on each individual batch. Batching consisted of mixing and milling the raw materials together, drying and screening the milled powder, calcining each composition at its required calcination temperature to produce the single phase NZP structure, and post calcination screening. Routine characterization such as powder X-ray diffraction, particle size measurement and surface area analysis was carried out to ensure that the powders had appropriate set of properties.

In order to obtain strong and dense components of the BSX and CSX series NZP materials, considerable effort was devoted to optimizing the existing process of fabricating slip cast components. This optimization procedure identified specific challenges that needed to be addressed such as milling process, use of appropriate binder and dispersant system and $\mathrm{pH}$ of the slurry. A systematic parametric study of these variables was then undertaken. Table 3 shows a typical experimental test matrix used to evaluate the effects of important variables involved in the fabrication process. Two important sub-processes, namely, calcination process and milling process were first evaluated.

The raw materials for a typical NZP ceramic viz., $\mathrm{Ba}_{1.25} \mathrm{Zr}_{4} \mathrm{P}_{5.5} \mathrm{Si}_{0.5} \mathrm{O}_{24}$ (BS-25), were blended in stoichiometric proportions and calcined at 1150 and $1200^{\circ} \mathrm{C}$ for 4 and 12 hours. These calcined samples were examined for their particle size, surface area and phase purity. Table 3 shows the results of particle size and surface area analysis as a function of calcination temperature and time. As is evident from this table, there is little correlation between calcination time and particle size or surface area. However, as the calcination temperature increases, the surface area is reduced significantly. The $\mathrm{X}$-ray diffraction patterns of Figure 8 of powders calcined at $1150^{\circ} \mathrm{C}$ vs. $1250^{\circ} \mathrm{C}$ show that the higher calcination temperature reduces the appearance of the second phase zirconium phosphate. Based on these results, it was determined that $1150^{\circ} \mathrm{C}$ is too low a temperature to calcine BS-25. Another independent calcination experiment showed that BS- 25 could be calcined at $1200^{\circ} \mathrm{C}$ without the formation of the second phase (Figure 9). The effect of time on the composition is negligible, hence, calcination at $1200^{\circ} \mathrm{C}$ for 4 hours was chosen as a standard calcination temperature. 

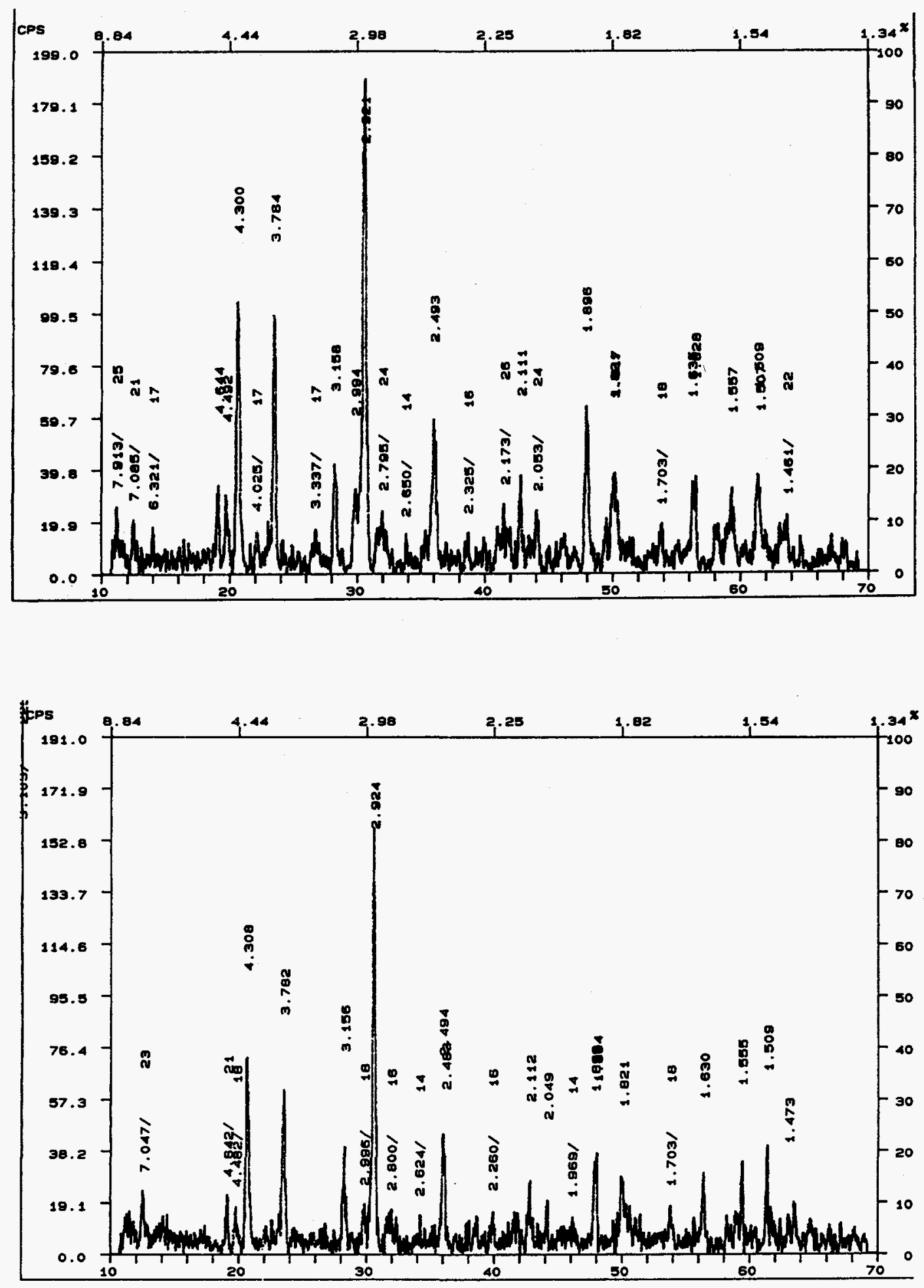

Figure 8 (a)\&(b). XRD traces of BS-25 powders calcined at (a) $1150^{\circ} \mathrm{C}$ and (b) $1250^{\circ} \mathrm{C}$. 


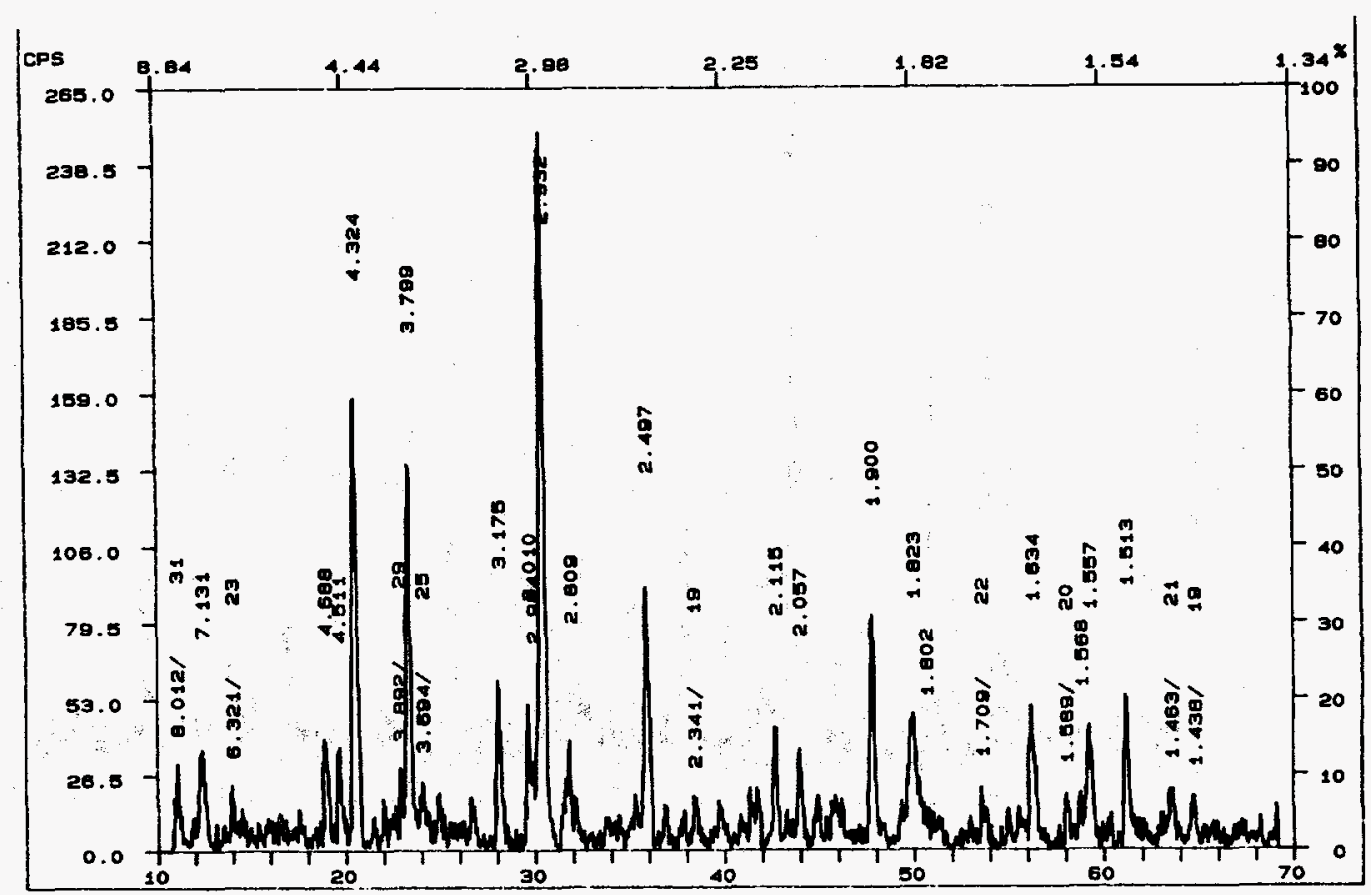

Figure 9. XRD pattern of BS-25 powder calcined at $1200^{\circ} \mathrm{C}$ showing only NZP phase.

Table 3. Results of Test Matrix for Evaluating and Improving Calcination Process.

\begin{tabular}{|c|c|c|}
\hline $\begin{array}{c}\text { Temperature } \Rightarrow \\
\text { Time } \Downarrow\end{array}$ & $1150^{\circ} \mathrm{C}$ & $1250^{\circ} \mathrm{C}$ \\
\hline 4 Hours & $\begin{array}{c}\text { Mean Particle Size: } 5.5 \mu \mathrm{m} \\
\text { Surface Area: } 1.27 \mathrm{~m}^{2} / \mathrm{g}\end{array}$ & $\begin{array}{c}\text { Mean Particle Size: } 5.5 \mu \mathrm{m} \\
\text { Surface Area: } 1.13 \mathrm{~m}^{2} / \mathrm{g}\end{array}$ \\
\hline & $\begin{array}{c}\text { Mean Particle Size: } 6.8 \mu \mathrm{m} \\
\text { Surface Area: } 1.65 \mathrm{~m}^{2} / \mathrm{g}\end{array}$ & $\begin{array}{c}\text { Mean Particle Size: } 5.5 \mu \mathrm{m} \\
\text { Surface Area: } 1.18 \mathrm{~m}^{2} / \mathrm{g}\end{array}$ \\
\hline
\end{tabular}


In order to determine the optimum milling conditions, a series of calcined samples (calcined at $1200^{\circ} \mathrm{C}$ for 4 hours) were milled by vibratory milling and ball milling. In the case of ball milling, two variables, the weight ratio of milling media to ceramic powder, and milling time were varied. In the case of vibratory milling, time was used as the only variable and media to powder weight ratio was held constant (at 6:1) due to the difficulties associated with changing this ratio in the vibratory mill. Particle size and surface area of these samples were measured after milling. Figure 10 illustrates the effect of milling media content and milling time on milling efficiency. This study indicates that vibratory milling is more efficient than ball milling with media to powder weight ratio of 5:1. When the media to powder ratio for ball milling is increased to $8: 1$, the efficiency of ball milling matches that of vibratory milling. However, such a high media to powder ratio during ball milling leads to contamination of the powders due to wear of the milling media. Thus, vibratory milling was considered a preferred milling technique. A typical batch size for the vibratory mill is approximateiy $25 \mathrm{lb}$. When smaller batches are needed ball milling with intermediate media-to-powder $(6: 1)$ ratio should be preferred, since the jar size is adjustable.

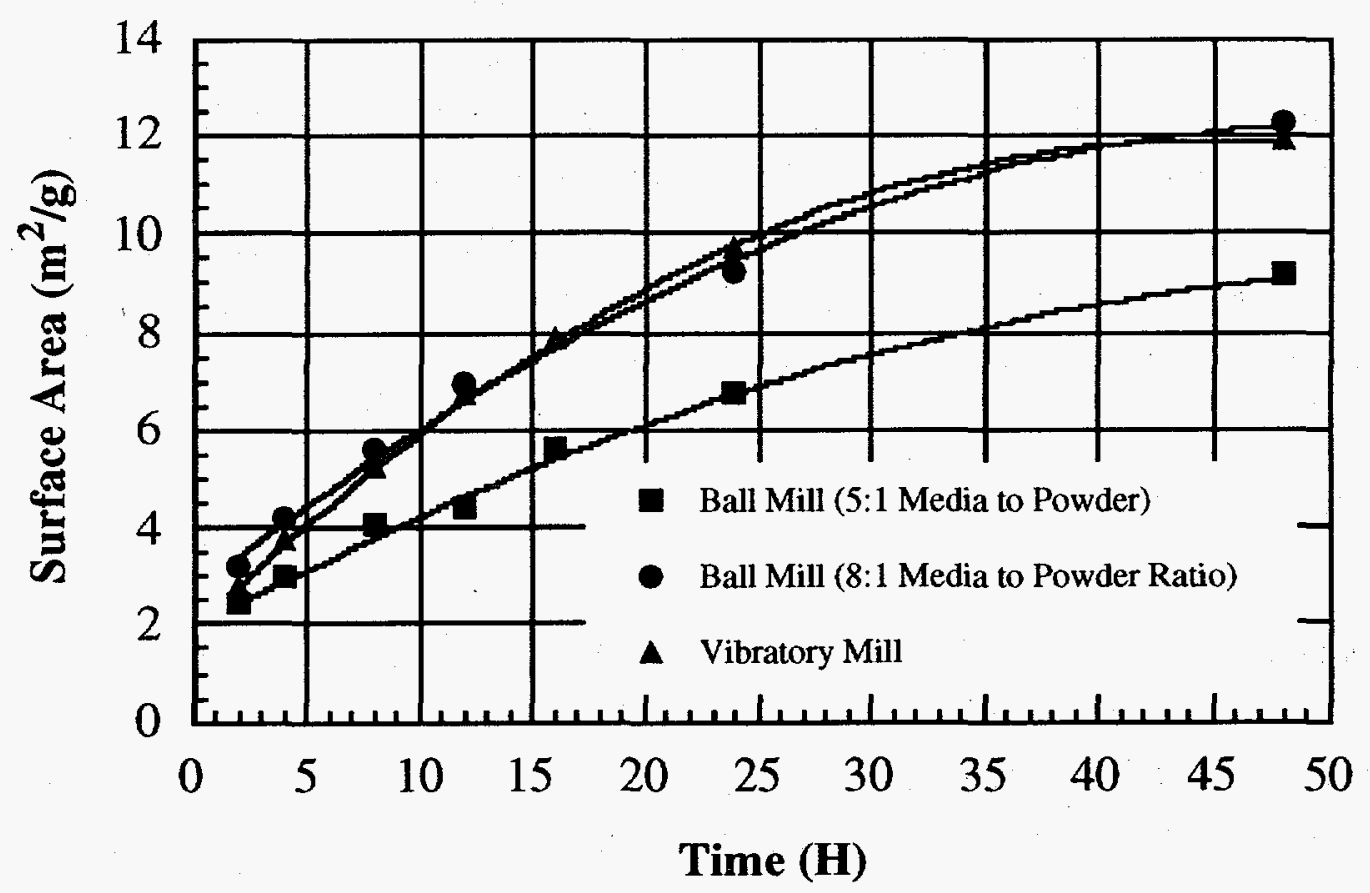

Figure 10. Effect of milling time and conditions on surface area of BS-25 powders calcined at $1200^{\circ} \mathrm{C}$ for 4 hours. 
The binder/dispersant system is a crucial factor in determining the success of the slip-casting process. Accordingly, several combinations of binders and dispersants were investigated for preparing slips of the various compositions. Some of the binders assessed were PEGs (Polyethylene Glycol) $\mathbf{T}$ and Goodrite K-type ${ }^{\S}$, and one of the evaluated dispersants was Darvan $\mathrm{C}^{\mathrm{TM}}$. Preliminary results showed that certain proprietary binders and dispersants performed better than others in providing satisfactory flow properties for the BS-25 system, although, even these binders and dispersants had a tendency to migrate to the surface during the drying stage of the slip casting process. New binders and dispersants are being evaluated to better optimize the rheological properties of the slip. Another important parameter that governs the flow characteristics of the slip and, thereby, the properties of the formed body is the $\mathrm{pH}$ of the slip. Studies to optimize the $\mathrm{pH}$ for slips of each composition are underway. A suitable binder-dispersant system and $\mathrm{pH}$ of the slip would lead to slip-cast bodies (such as port liners) with good properties and consistent quality.

Using the thusfar optimized process variables i.e., vibratory milling (media to powder ratio 5:1) and calcination of the milled and dried powders at $1200^{\circ} \mathrm{C}$ for 4 hours, ceramic slurry was prepared for slip casting by using the standard method of wet-milling the calcined powders with an appropriate dispersant, binder, and weight percent distilled water using grinding media. A series of tiles of size $2^{\prime \prime} \times 2^{\prime \prime} \times 0.25$ " were slip cast in molds with only small amounts of moisture (typically $5 \%$ by volume). Cast tiles were sintered at $1550^{\circ} \mathrm{C}$ for 4 hours - conditions determined to be optimum based on previous work on NZP ceramics. These tiles were then machined (sliced and ground) to appropriate shapes and sizes for further characterization.

\section{MATERIALS CHARACTERIZATION}

As-sintered BSX and CSX series specimens of appropriate sizes and shapes were used for preliminary characterization of mechanical properties (flexural strength, Weibull modulus, and elastic modulus), thermal properties (thermal conductivity, thermal expansion, thermal stability, and heat capacity), and microstructures. Because it was

I Union Carbide, Cleveland, $\mathrm{OH}$.

$\S$ BF Goodrich, Cleveland OH.

${ }^{\mathrm{r}}$ RT Vanderbilt Co., Norwalk CT. 
intended to study the effect of high temperature thermal cycling on important material properties, some of the specimens were subjected to 1,25 , and 250 heat-cool cycles between room temperature and $1250^{\circ} \mathrm{C}$ prior to a second stage of characterization. Compositions of the $\mathrm{BSX}\left(\mathrm{Ba}_{1+\mathrm{x}} \mathrm{Zr}_{4} \mathrm{P}_{6-2 \mathrm{x}} \mathrm{Si}_{2 \mathrm{x}} \mathrm{O}_{24}\right)$ series corresponding to $\mathrm{x}=0.0,0.17$, $0.25,0.375$ and 0.5 , and $\mathrm{CSX}\left(\mathrm{Ca}_{1-\mathrm{x}} \mathrm{Sr}_{\mathrm{x}} \mathrm{Zr}_{4} \mathrm{P}_{6} \mathrm{O}_{24}\right)$ series corresponding to $\mathrm{x}=0.25,0.375$ and 0.5 were evaluated. Characterization efforts at LoTEC and Penn State University were supplemented by work performed hy Mr. T. Barrett Jackson at the High Temperature Materials Laboratory (HTML) of ORNL as LoTEC's Industrial Fellow.

\section{Flexural Strength}

Both as-sintered and thermally cycled bar specimens of nominal dimensions 5.5 $\mathrm{mm} \times 6.5 \mathrm{~mm} \times 50 \mathrm{~mm}$ were first prepared. The tension face of the each bar was then polished to a fine finish and its edges chamfered. Fracture loads ( $\mathrm{P}_{\mathrm{f}}$ in Newtons) of the bar samples subjected to four-point bending were first determined using loading fixtures and procedures recommended in Ref. 6 . The cross head speed was $0.5 \mathrm{~mm} / \mathrm{min}$. and the load at failure was recorded. From the load at failure and the cross-sectional dimensions of the test specimens the flexural strength was calculated. The fracture strengths $\left(\sigma_{\mathrm{f}}\right.$ in $\mathrm{MPa}$ ) were then calculated using the elastic bending formula given below:

$$
\sigma_{\mathrm{f}}=\frac{1.5 \mathrm{P}_{\mathrm{f}}(\mathrm{S}-1)}{\mathrm{b} \mathrm{t}^{2}}
$$

where, $b$ and $t$ represent the width and thickness, respectively, of the bar samples.

Table 4 provides the room temperature flexure strength data of both as-sintered and thermally cycled $\left(1250^{\circ} \mathrm{C}\right)$ specimens along with the standard deviation $(\mathrm{m})$ of each set of data. Three important observations can be made from Table 4: (i) flexure strengths of BS-25 and CS-50 are the highest among the BSX and CSX compositions, respectively, irrespective of the extent of thermal cycling ( 0 to 250 cycles), (ii) there is no noticeable degradation in strengths of the BS-25 and CS-50 materials even after 250 cycles at $1250^{\circ} \mathrm{C}$ (see Figs. 11 (a) \& (b)), and (iii) standard deviations and, hence, Weibull modulii of strengths of the BS-25 and CS-50 materials are reasonably high. This is indicative of the superior low and high temperature mechanical properties of the BS-25 and CS-50 compositions in the BSX and CSX system, respectively. However, between the two, the BS-25 material possesses better mechanical properties. 

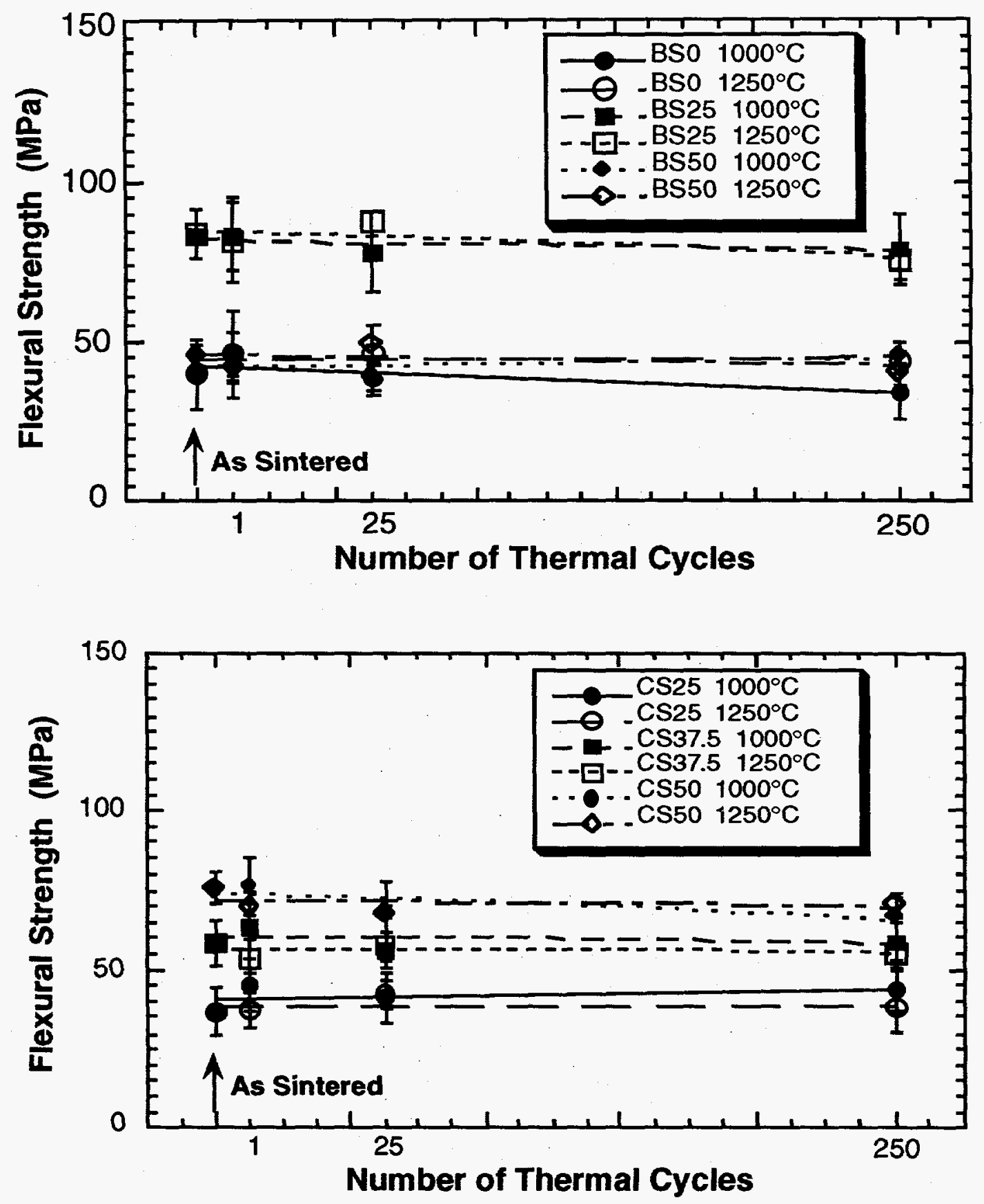

Figure 11 (a)\&(b). Flexure strength 'vs.' number of thermal cycles to $1250^{\circ} \mathrm{C}$ for (a) BSX and (b) CSX compositions. 
Table 4. Summary of the room temperature flexural strengths of as-sintered and thermally-cycled $\left(1250^{\circ} \mathrm{C}\right) \mathrm{BSX}$ and CSX materials.

\begin{tabular}{|l|c|c|c|c|}
\hline \multicolumn{5}{|c|}{ Thermal Cycling between R.T and $1250^{\circ} \mathrm{C}$} \\
\hline \multirow{2}{*}{$\begin{array}{c}\text { Composition } \\
\text { (BSX and CSX) }\end{array}$} & As Sintered & 1 Cycle & 25 Cycles & 250 Cycles \\
\cline { 2 - 5 } & $40.13 \pm 10.85$ & $46.52 \pm 6.34$ & $46.90 \pm 2.24$ & $44.25 \pm 3.29$ \\
\hline BS-0 & $49.76 \pm 5.61$ & $46.53 \pm 4.90$ & - & $46.49 \pm 4.95$ \\
\hline BS-17 & $84.20 \pm 7.61$ & $81.43 \pm 12.51$ & $88.19 \pm 3.03$ & $75.92 \pm 5.95$ \\
\hline BS-25 & $46.13 \pm 4.13$ & $46.82 \pm 6.59$ & $48.99 \pm 6.17$ & $45.14 \pm 6.16$ \\
\hline BS-37.5 & $45.55 \pm 3.48$ & $42.50 \pm 3.61$ & $49.19 \pm 6.70$ & $41.21 \pm 4.76$ \\
\hline BS-50 & & & & \\
\hline & $36.87 \pm 7.55$ & $37.47 \pm 5.36$ & $42.02 \pm 4.73$ & $37.95 \pm 7.26$ \\
\hline CS-25 & $58.41 \pm 6.82$ & $53.88 \pm 5.57$ & $57.60 \pm 4.73$ & $54.90 \pm 5.17$ \\
\hline CS-37.5 & $75.52 \pm 4.83$ & $69.81 \pm 4.91$ & $67.88 \pm 1.62$ & $70.16 \pm 3.86$ \\
\hline CS-50 & & & & \\
\hline
\end{tabular}

\section{Thermal Diffusivity}

Thermal diffusivity measurements were made using a xenon flash system. Eight different compositions viz., BS-0, BS-17, BS-25, BS-37.5, BS-50, CS-25, CS-37.5, and CS-50 were characterized at room temperature; and the thermal diffusivity of only the BS-25 composition was evaluated as a function of temperature. Five test specimens of each composition were prepared and thermal diffusivity measured. Test specimens consisted of disks $12.5 \mathrm{~mm}$ in diameter and approximately $1.5 \mathrm{~mm}$ thick. The test specimens were first coated with a layer of $\mathrm{Au} / \mathrm{Pd}$ followed by a layer of colloidal graphite. The metal layer prevents light penetration into the sample and the graphite layer enhances the absorption of the xenon light pulse at the face of the sample. The heat rise as a function of time was measured at the rear face of the sample.

Results of thermal diffusivity measurements are given in Table 5. The thermal diffusivity value for each test specimen is the average of 10 acceptable measurements. 
Table 5. Thermal Diffusivity of various BSX and CSX Compositions.

\begin{tabular}{|c|c|}
\hline Composition & $\begin{array}{c}\text { Thermal Diffusivity } \\
\left(\mathrm{cm}^{2} / \mathrm{sec} .\right)\end{array}$ \\
\hline BS-0 & 0.0071 \\
\hline BS-17 & 0.0064 \\
\hline BS-25 & 0.0061 \\
\hline BS-37.5 & 0.0052 \\
\hline BS-50 & 0.0051 \\
\hline CS-25 & 0.0058 \\
\hline CS-37.5 & 0.0063 \\
\hline CS-50 & 0.0070 \\
\hline
\end{tabular}

There was less than $1 \%$ difference between the acceptable measurements. In addition, there was excellent agreement between the 5 test specimens of each composition. The density of the test specimens ranged from $85 \%$ to $90 \%$ of theoretical. Therefore, a correction for differences in porosity would have to be made when thermal conductivity is calculated.

\section{Heat Capacity}

Measurement of specific heat capacity of all compositions was important to calculate the thermal conductivity from thermal diffusivity and the density data. However, only the BS-25 material has been cvaluated in this Phase I program. (The characterization of the CS-50 and other materials has been scheduled for the ongoing Phase II work.) Specimens for heat capacity measurement were made by core drilling $1.5 \mathrm{~mm}$ plates to produce a $4 \mathrm{~mm}$ disk. Three specimens of the BS- 25 composition were made. After drilling, the specimens were clean fired to $1000^{\circ} \mathrm{C}$ and held at temperature for 2 hours. The heat capacity measurements were conducted in a differential scanning calorimeter (DSC). These values have been tabulated in Table 6 below. 
Thermal Conductivity

Using the measured thermal diffusivity and specific heat data, and the density of the test specimen, the thermal conductivity of BS-25 was calculated from Equation 2, which relates thermal conductivity, $\kappa$, to thermal diffusivity, $\alpha$, specific heat capacity, $c_{p}$, and density, $\rho$;

$$
\alpha=\frac{k}{\rho c_{p}}
$$

Table 6 and Figure 12 provide the values of thermal conductivity of BS-25 as a function of temperature up to $1100^{\circ} \mathrm{C}$. Similar data are being compiled for the other compositions as part of the ongoing Phase II research.

\section{Thermal Expansion}

Thermal expansion measurements were made on as-sintered and thermally cycled ( 1 to 250 cycles from R.T. to $1250^{\circ} \mathrm{C}$ ) BSX and CSX compositions. Two as-sintered specimens of each composition were tested to confirm the consistency of data from sample to sample. The results of these runs have been presented for three compositions of the BSX series and two of the CSX series in Figures 13-17. From these figures, it is clear that sample to sample difference of thermal expansion data is very small.

Table 6. Thermal Conductivity ( $\mathrm{k}$ ) of BS-25 material as a function of temperature.

\begin{tabular}{|c|c|c|c|c|}
\hline $\begin{array}{c}\text { Temperature } \\
{ }^{\circ} \mathrm{K}\left({ }^{\circ} \mathrm{C}\right)\end{array}$ & $\begin{array}{c}\mathrm{c}_{\mathrm{p}} \\
(\mathrm{cal} / \mathrm{gm})\end{array}$ & $\begin{array}{c}\alpha \\
\left(\mathrm{cm}^{2} / \mathrm{sec}\right)\end{array}$ & $\begin{array}{c}\rho \\
(\mathrm{gm} / \mathrm{cc})\end{array}$ & $\begin{array}{c}\kappa \\
\left(\mathrm{W} / \mathrm{m}^{\circ} \mathrm{K}\right)\end{array}$ \\
\hline $298.15(25)$ & 0.4898 & 0.0061 & 3.09 & 0.9232 \\
$373.15(100)$ & 0.5548 & 0.0056 & 3.09 & 0.9600 \\
$573.15(300)$ & 0.6449 & 0.0051 & 3.09 & 1.0163 \\
$773.15(500)$ & 0.6884 & 0.0049 & 3.09 & 1.0424 \\
$973.15(700)$ & 0.7141 & 0.0046 & 3.09 & 1.0150 \\
$1173.15(900)$ & 07310 & 0.0048 & 3.09 & 1.0841 \\
$1373.15(1100)$ & 0.7429 & 0.0050 & 3.09 & 1.1478 \\
\hline
\end{tabular}




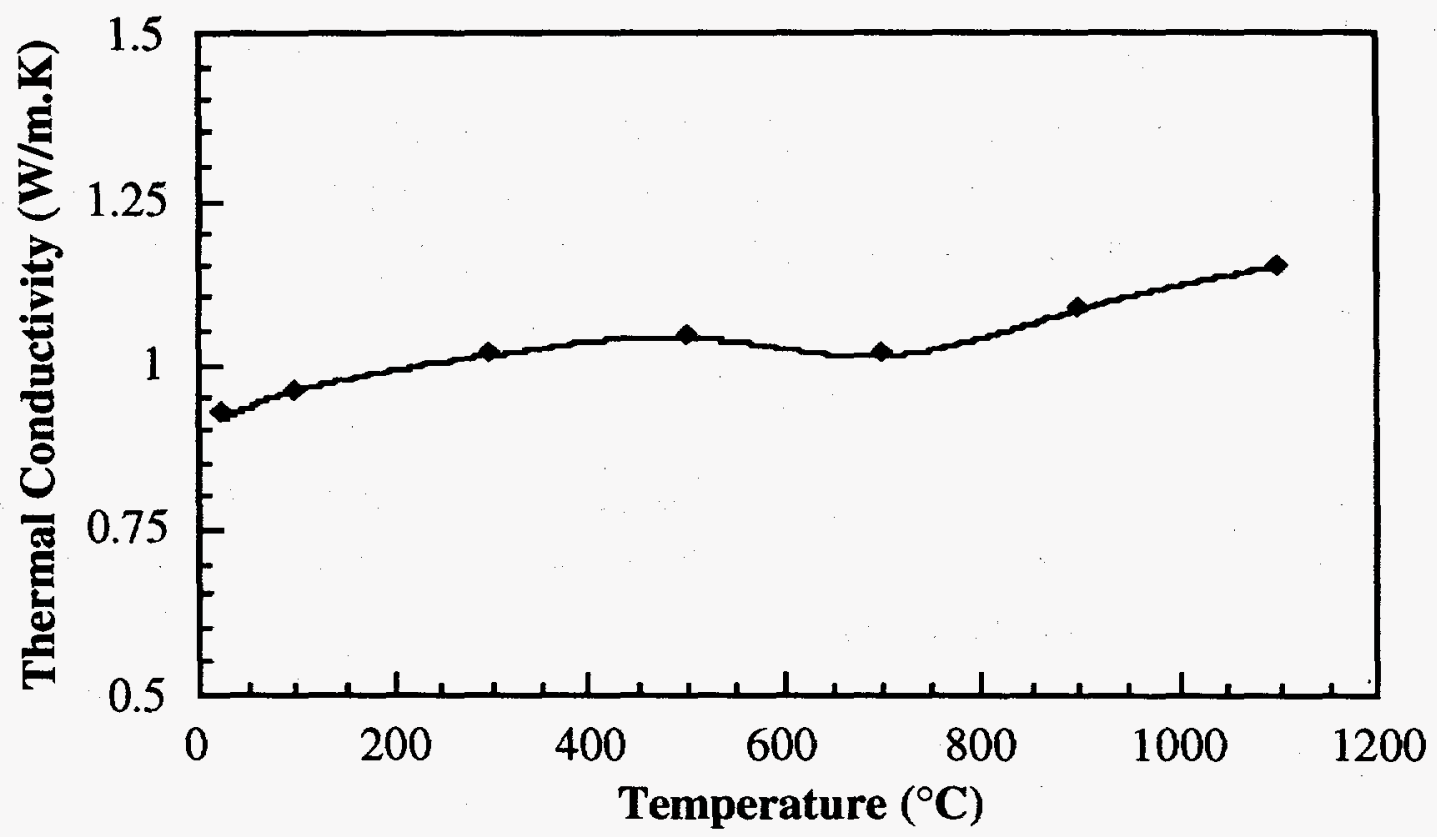

Figure 12. Thermal Conductivity of BS-25 composition as a function of temperature.

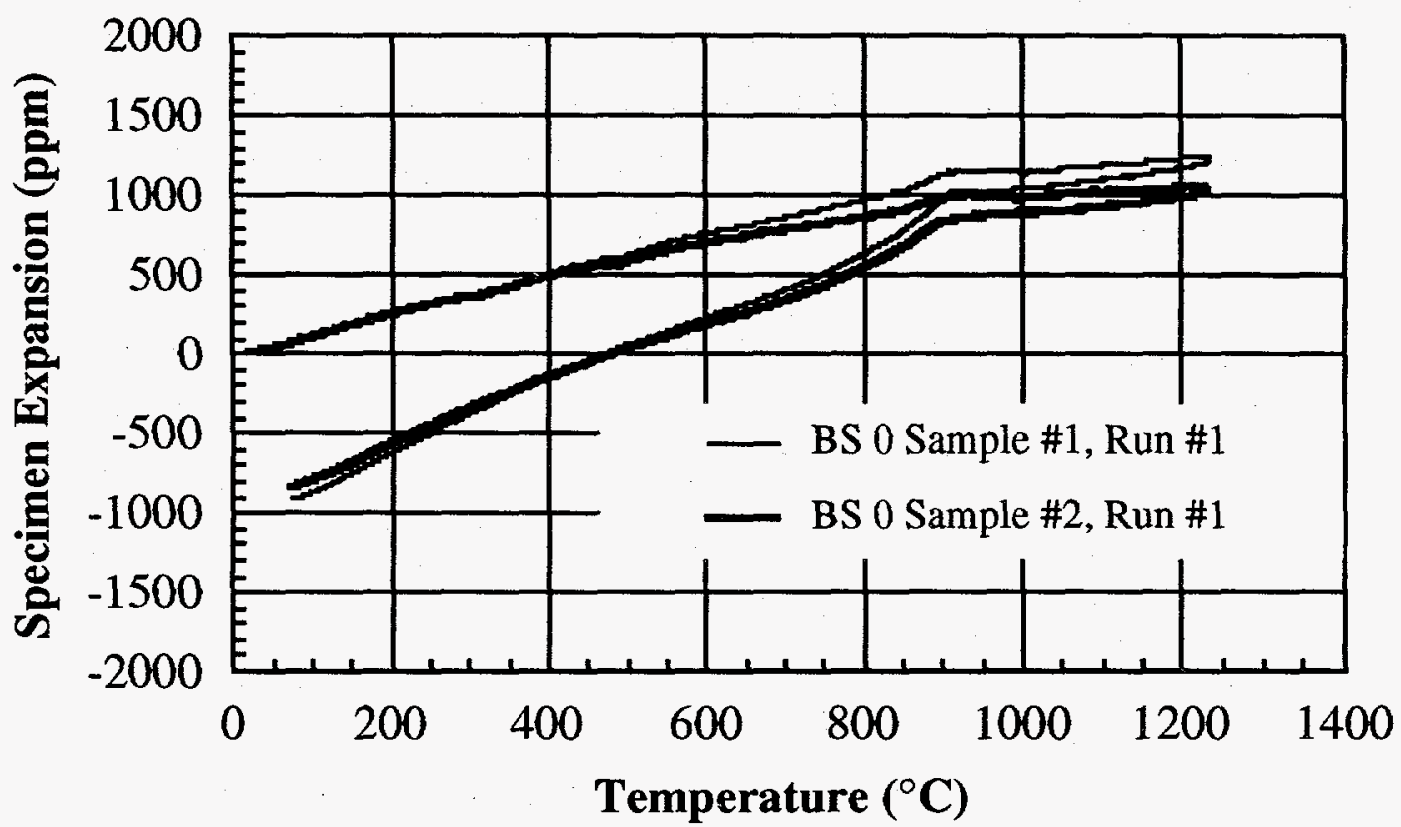

Figure 13. Thermal expansion measurements of two different samples of BS-0 composition. 


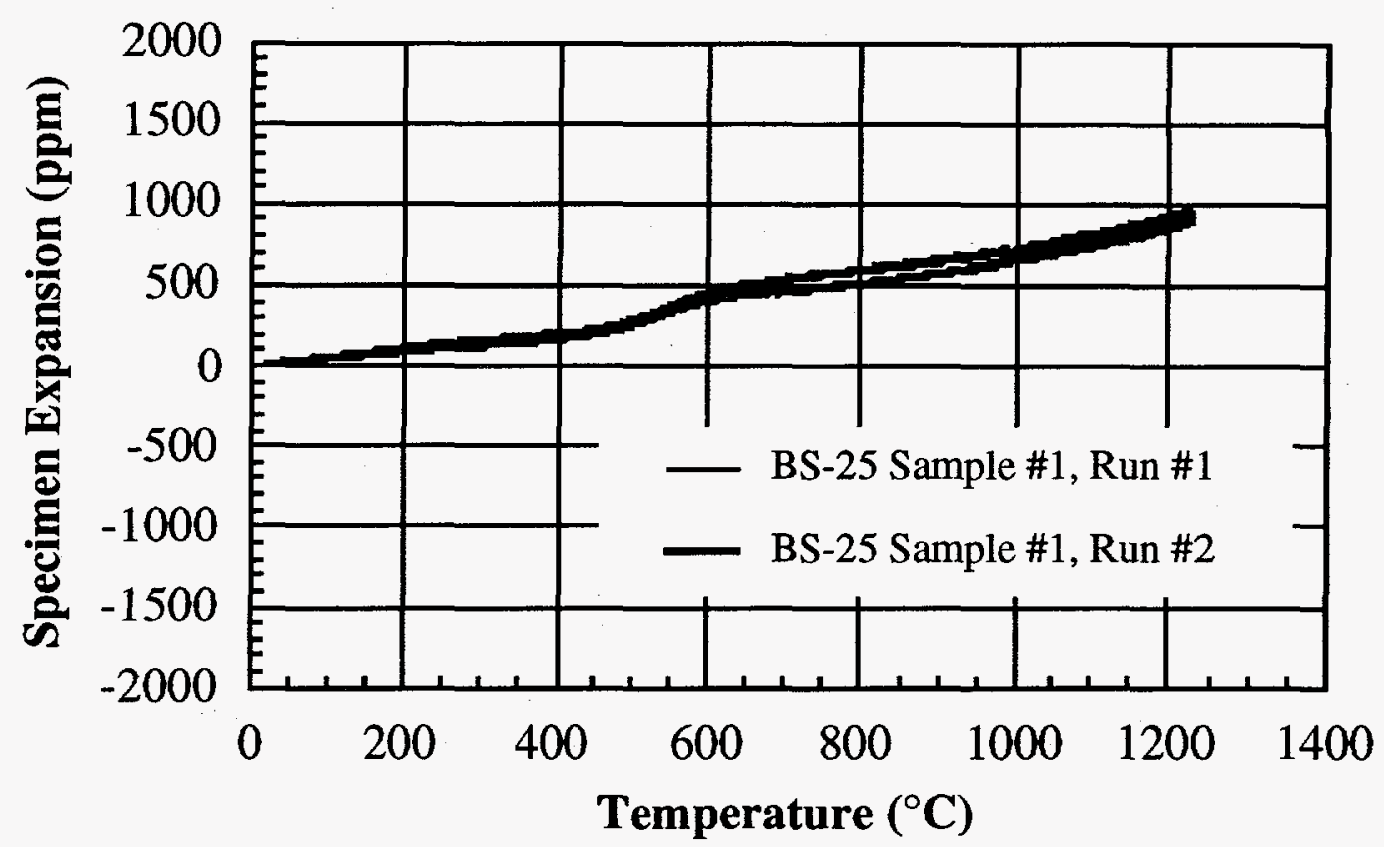

Figure 14. Thermal expansion measurements of two different samples of BS-25 composition.

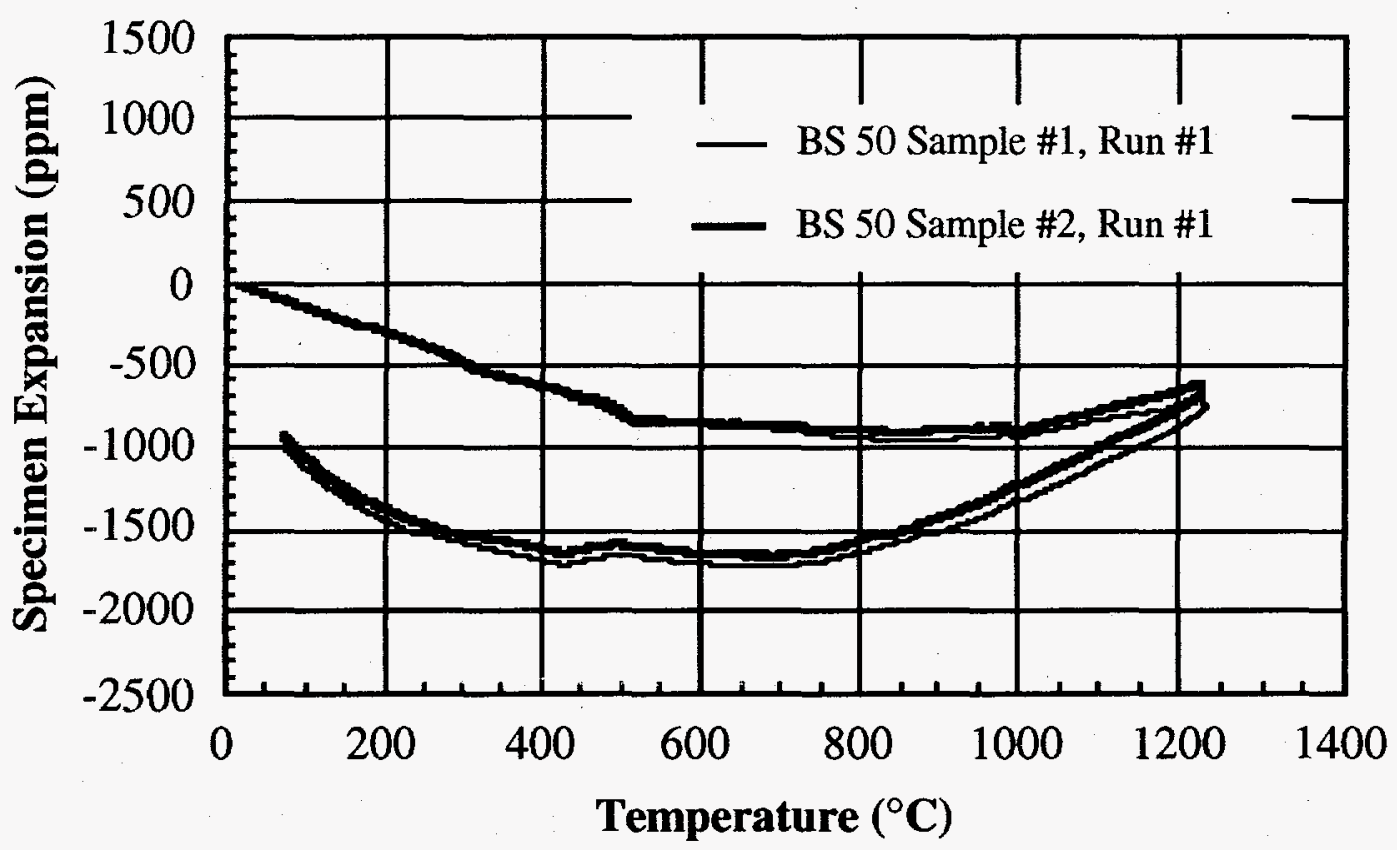

Figure 15. Thermal expansion measurements of two different samples of BS-50 composition. 


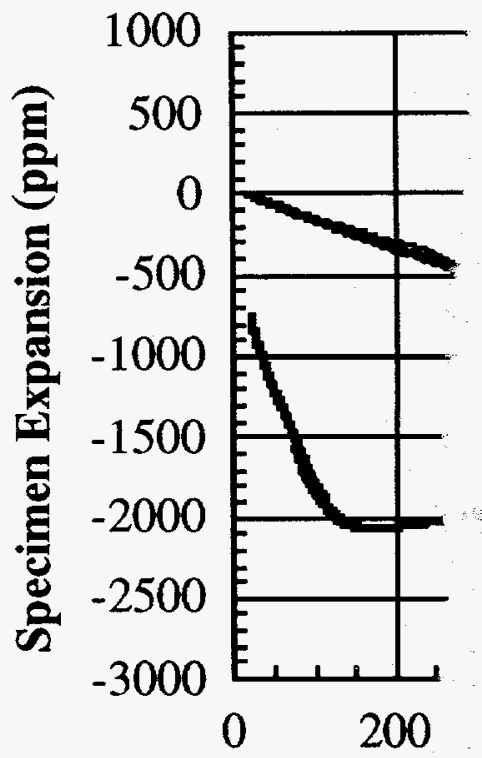

Figure 16. Thermal ex

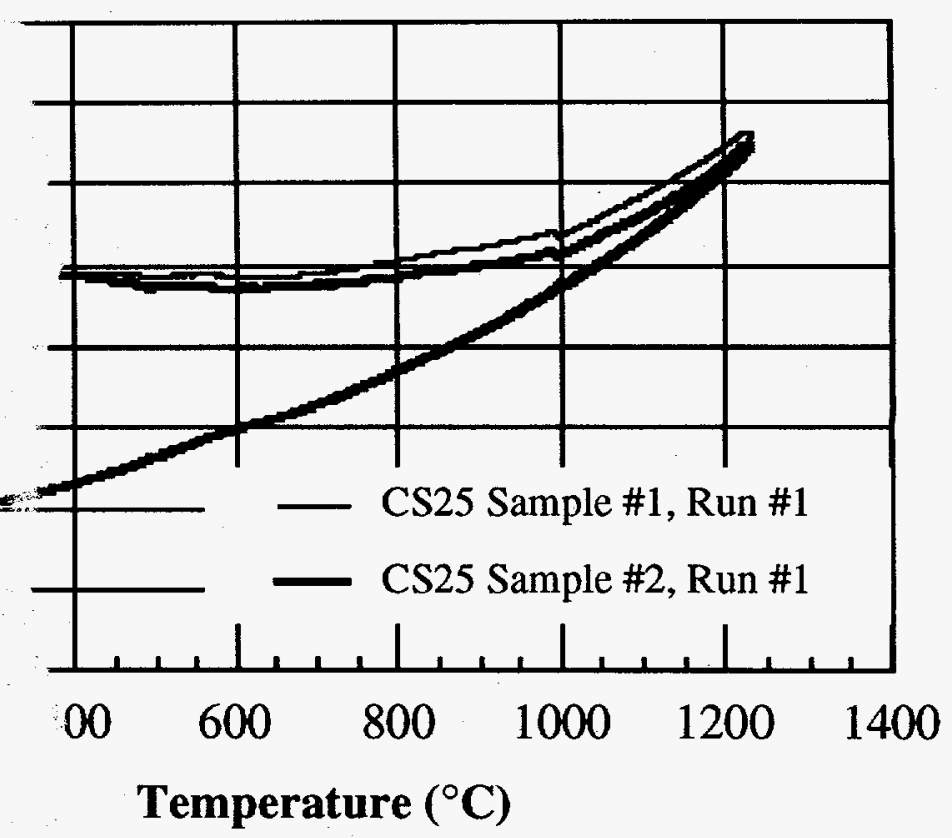

n measurements of two different samples of CS-25 composition.

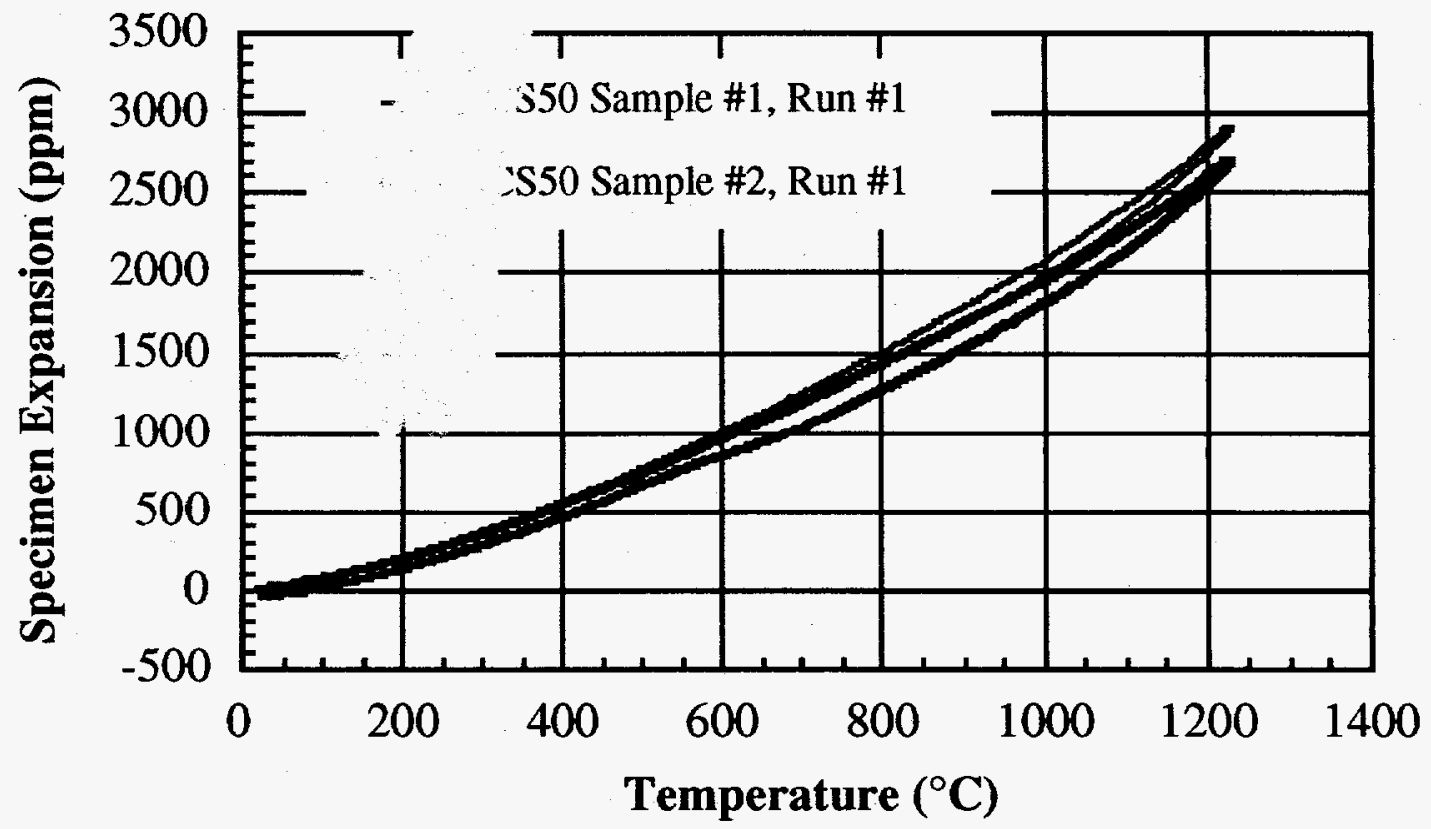

Figure 17. Thermal expansion measurements of two different samples of CS-50 composition. 
Figures 18-22 show the bulk thermal expansion curves for the various as-sintered and thermally cycled BSX compositions. Several interesting observations could be made with respect to these thermal expansion curves. Samples of different compositions from the BSX series exhibit varying degrees of anisotropy as a function of concentration of silicon upon thermal cycling. BSX materials that exhibit high degree of thermal expansion anisotropy - BS-0, BS-37.5 and BS-50 - tend to have large thermal hysteresis which decreases with increasing amount of cycling and those with small anisotropy - BS17 and BS-25 - have relatively negligible hysteresis. In the range of $x=0.00$ to $x=0.50$, one particular composition $-\mathrm{x} \approx 0.22$ - showed no (zero) anisotropy. The anisotropic compositions from the BSX series show a permanent shrinkage associated with cooling of the specimen during thermal expansion measurements. These trends have been depicted in Figure 23 which is a plot of the effect of composition on thermal expansion anisotropy for the BSX series of materials.

Similarly, in the CSX compositional series, $\mathrm{Ca}_{0.5} \mathrm{Sr}_{0.5} \mathrm{Zr}_{4} \mathrm{P}_{6} \mathrm{O}_{24}$ (CS-50) shows minimal thermal expansion anisotropy and hence it has the least amount of thermal expansion hysteresis associated with it. Figures 24 through 26 show the thermal expansion curves for the as-sintered and thermally cycled CSX materials. From these curves it can be noted that the highly anisotropic CS-25 and CS-37.5 materials show extensive shrinkage up to $150^{\circ} \mathrm{C}$ and anomalous expansion as they cool below $150^{\circ} \mathrm{C}$. As with the BS compositions, the hysteresis associated with the CS materials decreases with the extent of cycling.

To understand better the difference in thermal hysteresis behaviors between the isotropic and anisotropic compositions, one specimen each of the isotropic type - BS-25 and anisotropic type - CS-25 - was cycled 3 times to $1250^{\circ} \mathrm{C}$ in a He atmosphere. The results of these runs revealed that the BS-25 material has an average expansion of 0.5 $\mathrm{ppm} /{ }^{\circ} \mathrm{C}$ over this temperature range, with very little difference from run to run. The hysteresis was small and the specimen returned to its original length after each run. On the other hand, the CS-25 test bars subjected to thermal cycling between $20^{\circ} \mathrm{C}$ and $1250^{\circ} \mathrm{C}$ in $\mathrm{He}$ atmosphere showed the expected anomalous expansion behavior below $150^{\circ} \mathrm{C}$. This behavior was believed to be possibly due to room temperature microcracking. The phenomenon that furthered this belief was the continued expansion of the test specimen after it had cooled to room temperature (see Figure 27). This room temperature expansion was enhanced in the presence of room air $(70 \%$ to $80 \%$ relative humidity) suggesting a possible reaction with either oxygen or water vapor. The 


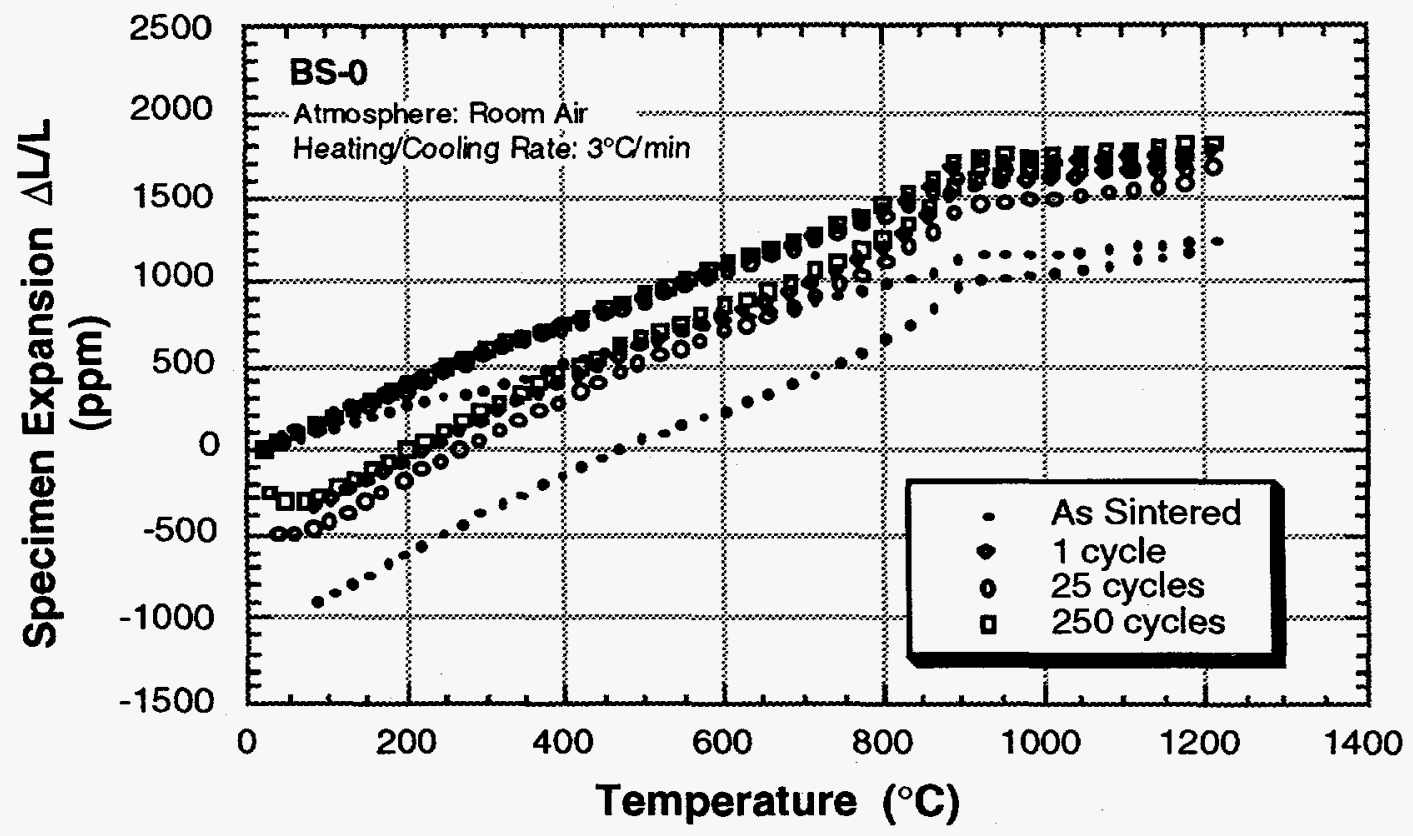

Figure 18. Effect of thermal cycling on the bulk linear thermal expansion of BS-0 material.

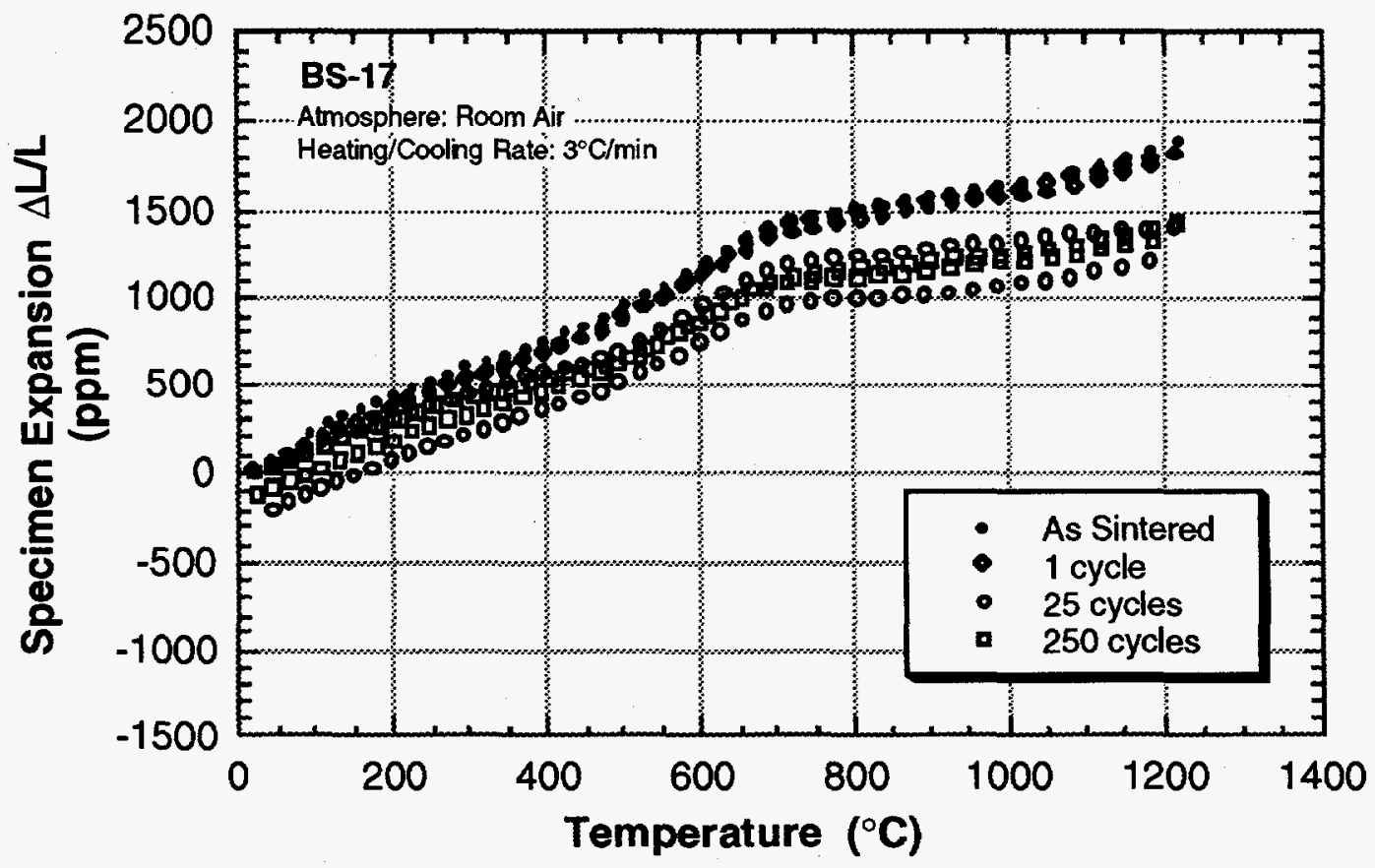

Figure 19. Effect of thermal cycling on the bulk linear thermal expansion of BS-17 material. 


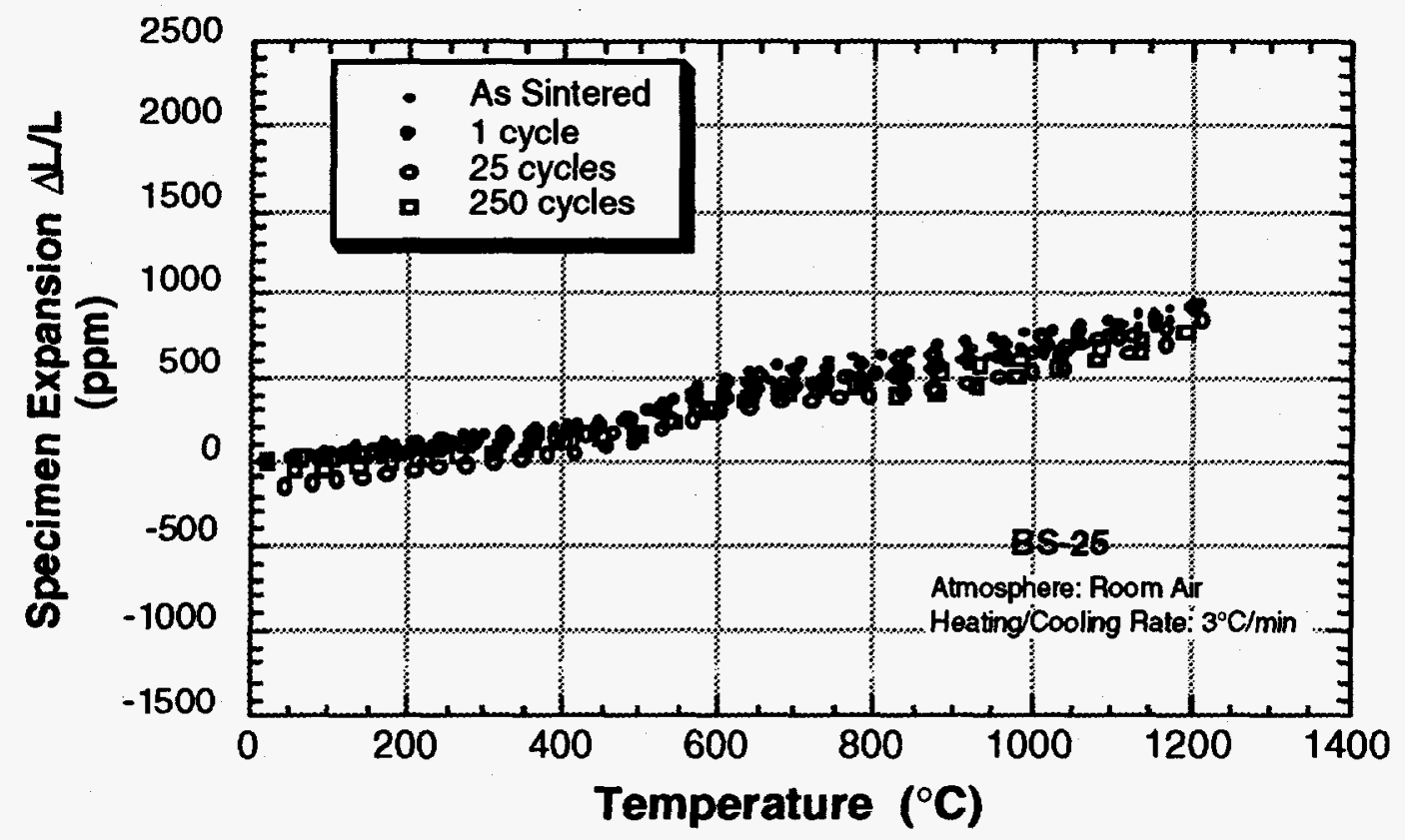

Figure 20. Effect of thermal cycling on the bulk linear thermal expansion of BS-25 material.

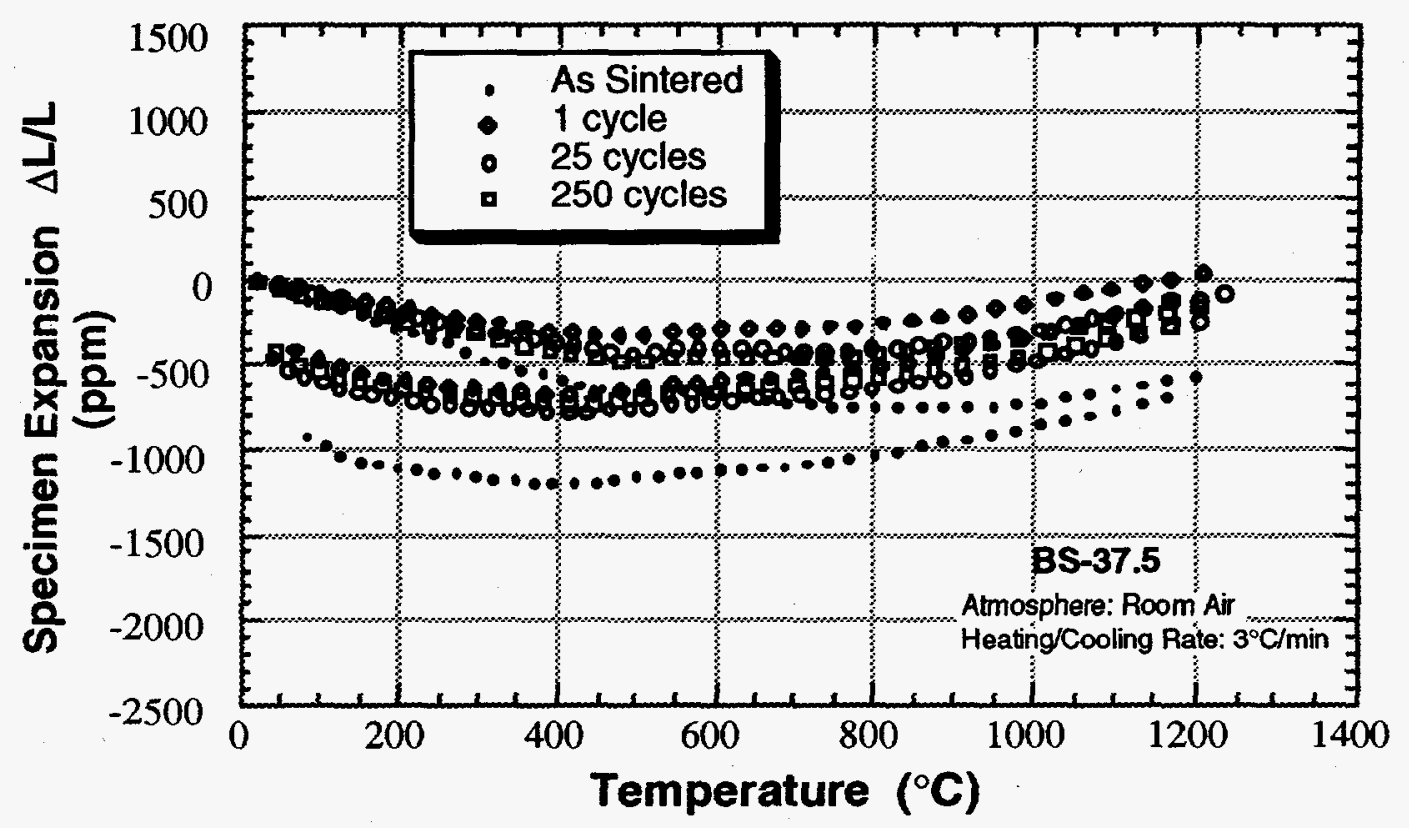

Figure 21. Effect of thermal cyciing on the bulk linear thermal expansion of BS-37.5 material. 


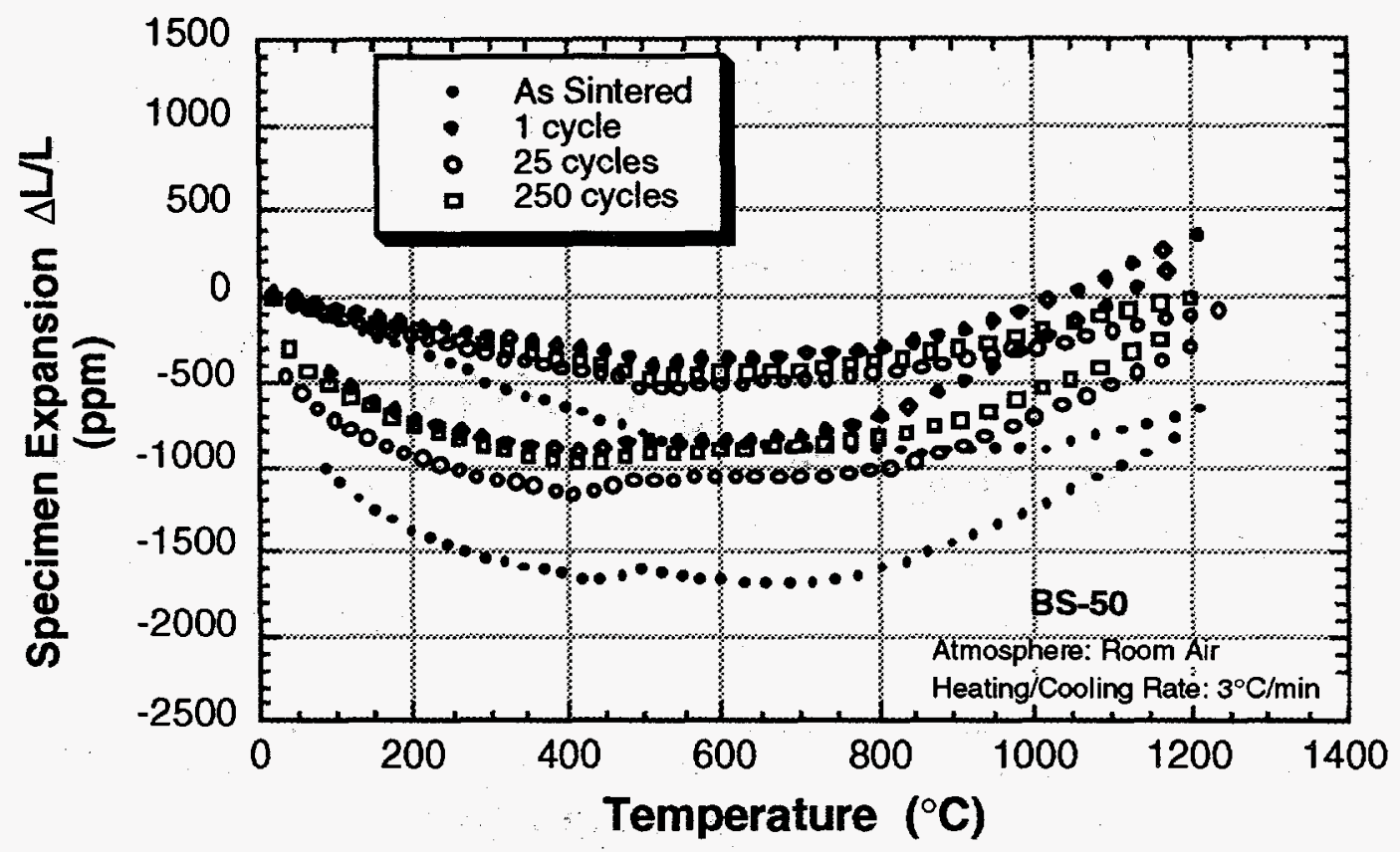

Figure 22. Effect of thermal cycling on the bulk linear thermal expansion of BS-50 material.

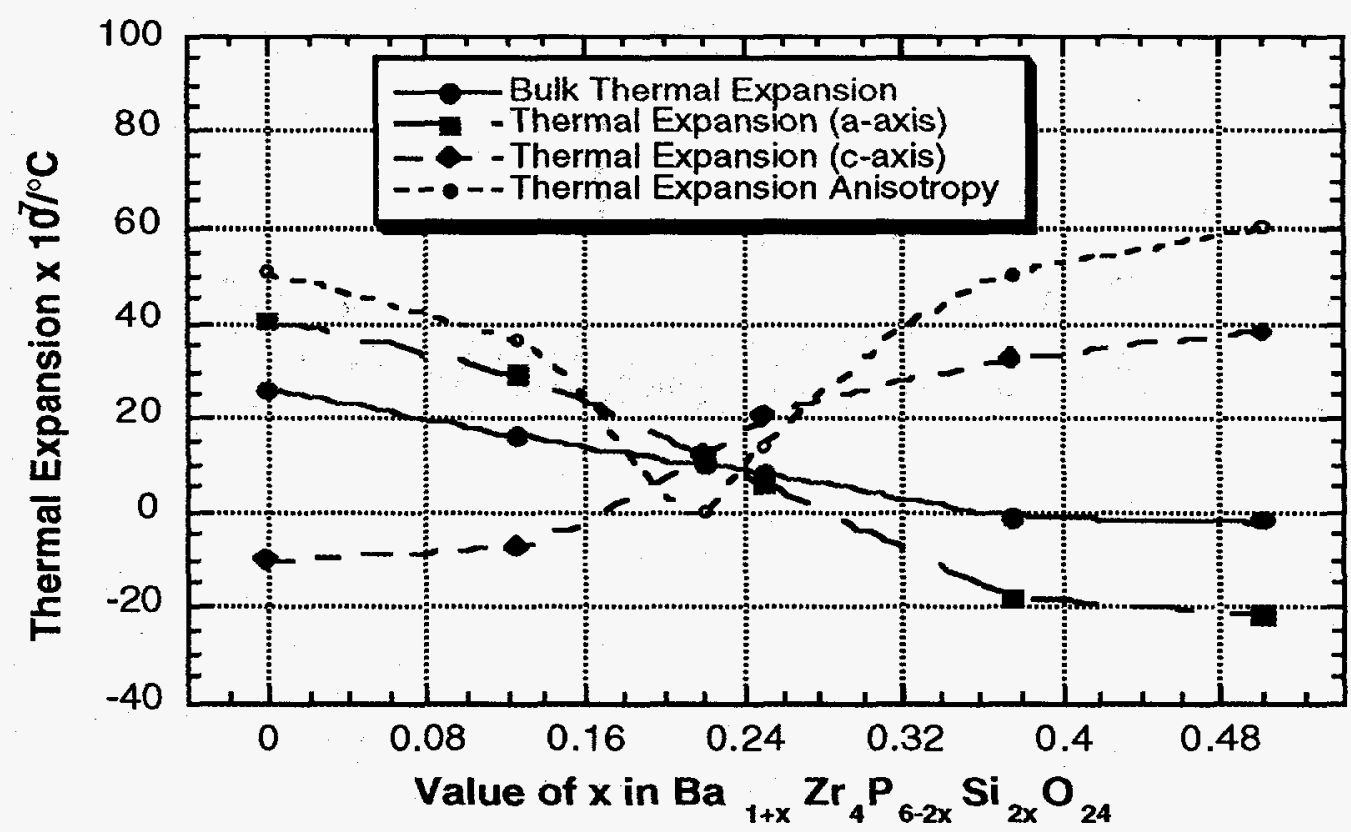

Figure 23. Thermal expansion anisotropy and the axial expansion of BSX as a function of composition (silicon content). 


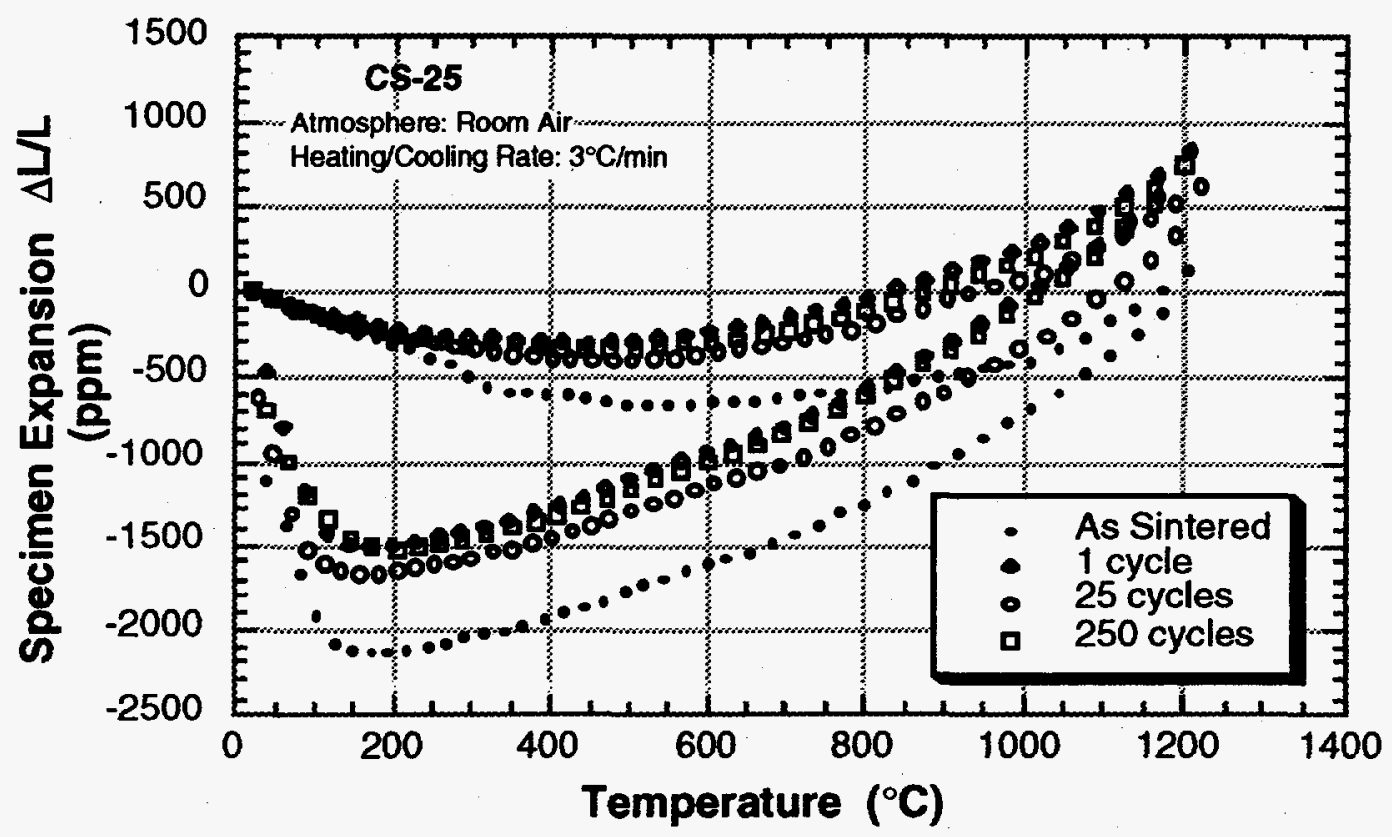

Figure 24. Effect of thermal cycling on the bulk linear thermal expansion of CS-25 material.

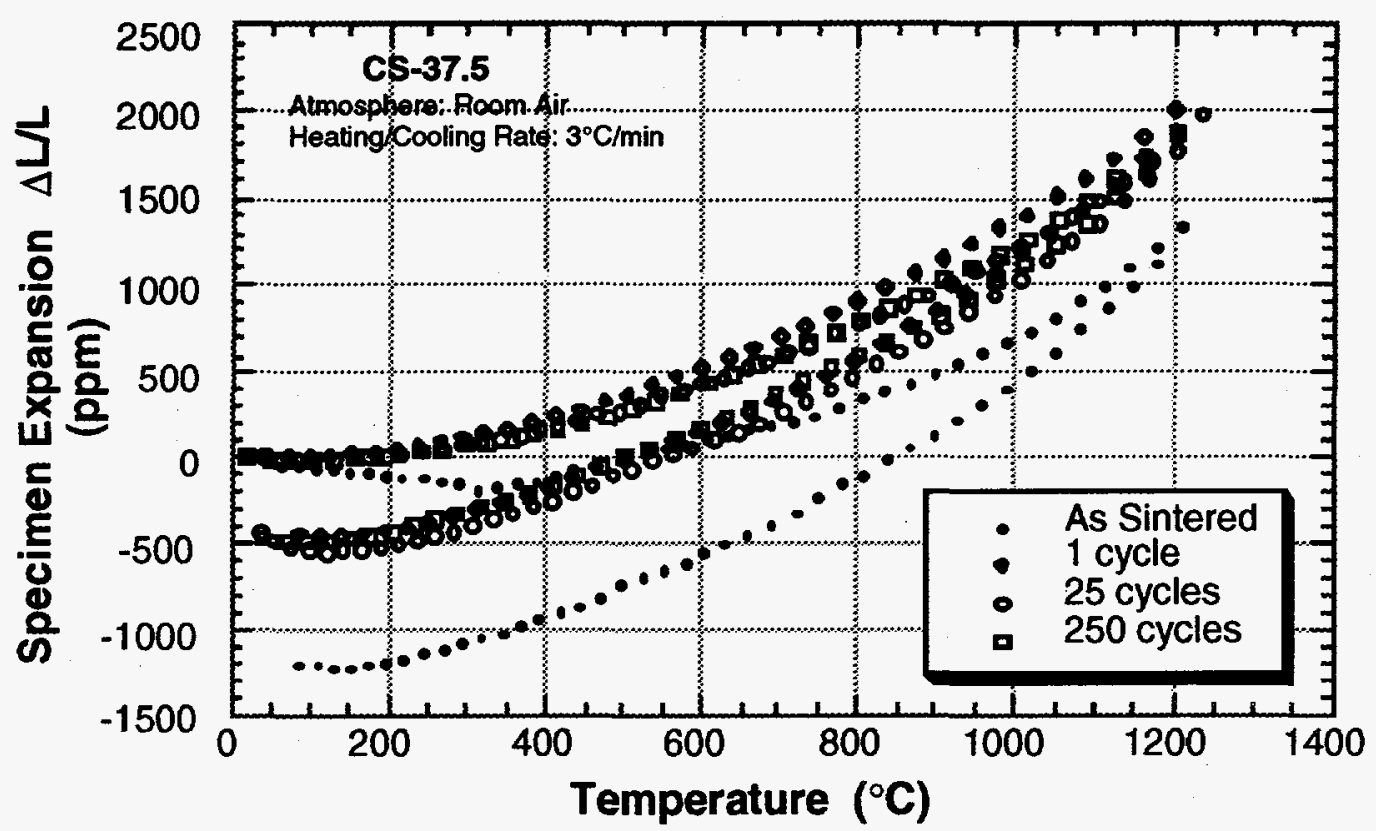

Figure 25. Effect of thermal cycling on the bulk linear thermal expansion of CS-37.5 material. 


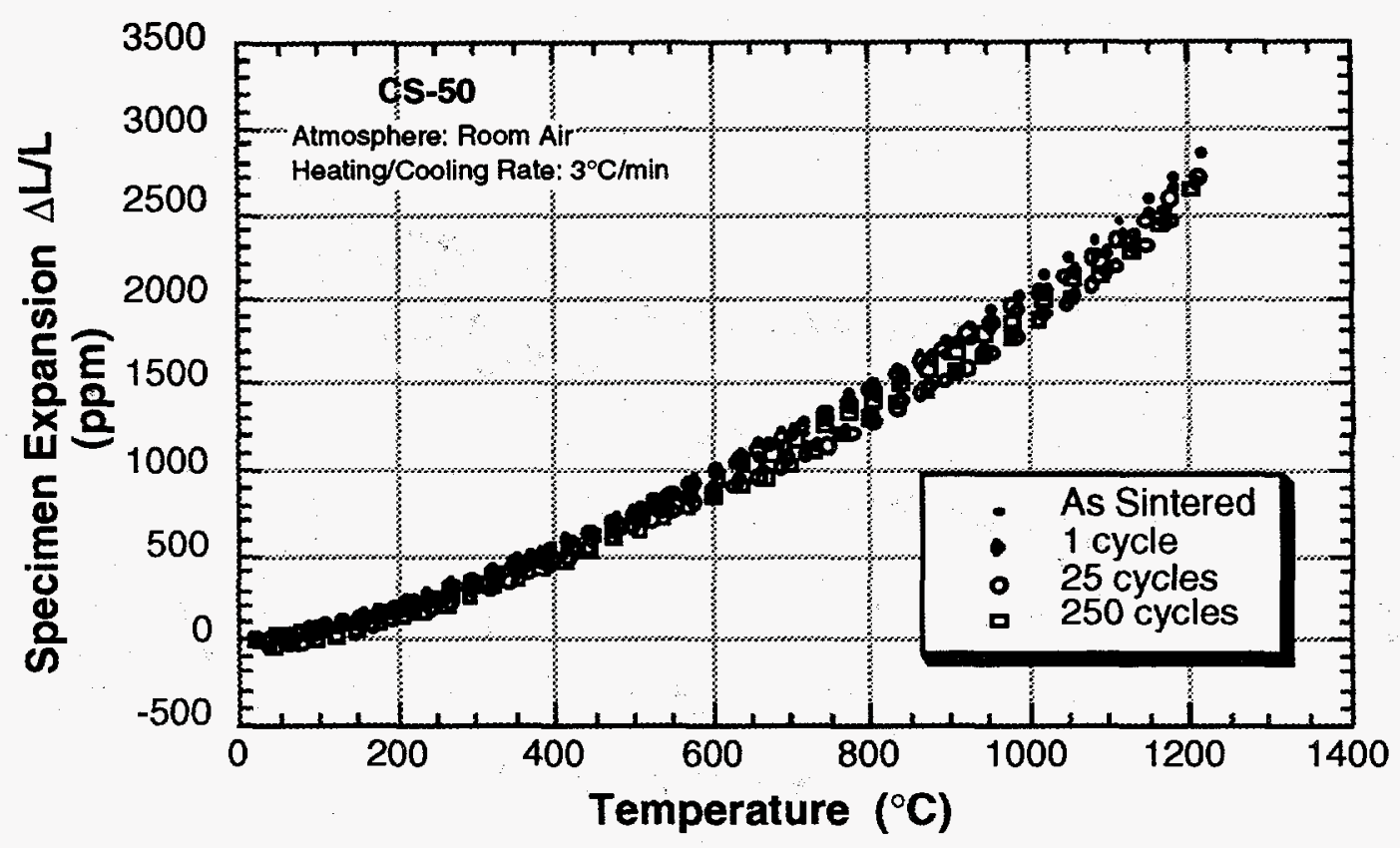

Figure 26. Effect of thermal cycling on the bulk linear thermal expansion of CS-50 material.

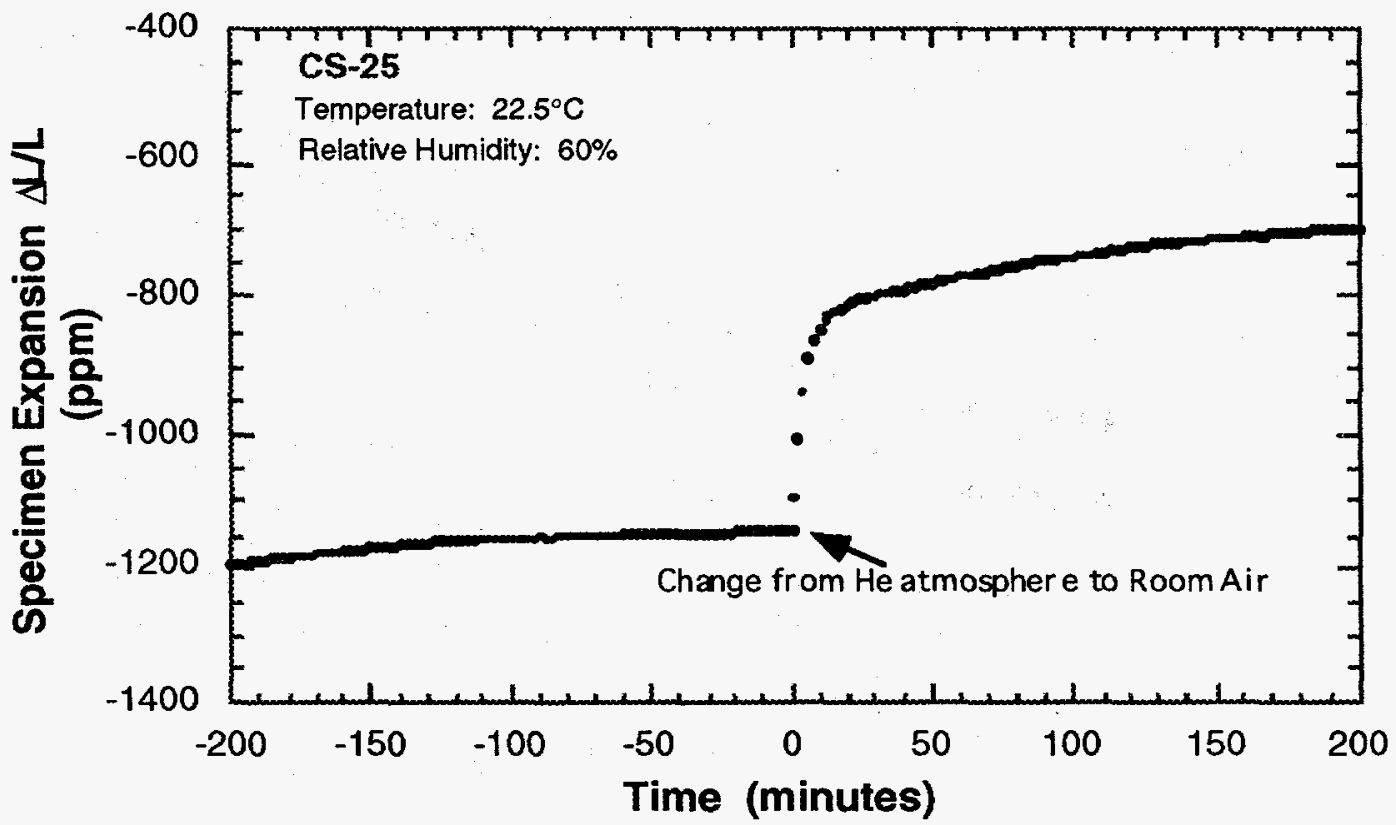

Figure 27. Room temperature expansion of CS-25 material in the presence of air. 
specimen also exhibited considerable hysteresis and some permanent change in length. After 3 cycles between $20^{\circ} \mathrm{C}$ and $1250^{\circ} \mathrm{C}$, measurement of the length of the test specimen after removal from the dilatometer revealed a decrease in length of $0.03 \mathrm{~mm}$ (corresponding to 0.12 percent).

With these results, it was conceived that the isotropic compositions (BS-25 and CS50) have little or no microcracking associated with cooling from either the sintering temperature or the heat treatment temperature. Without the presence of microcracking there is very little thermal hysteresis and thus very reproducible thermal expansion curves. Whereas, the anisotropic compositions (BS-0, BS-37.5, BS-50, CS-25, and CS37.5) microcrack upon cooling from the sintering temperature and thus have thermal expansion curves with varying amounts of hysteresis.

In the BSX compositions, it was speculated that many of the microcracks close above $1200^{\circ} \mathrm{C}$ and the intergranular stresses due to thermal expansion anisotropy are not strong enough to open the microcracks at room temperature. As a result there is net shrinkage associated with thermal cycling. During subsequent cycles, the number of microcracks closing would be less and hence there is less shrinkage associated with the second cycle and so on during the cooling process.

In the case of CSX compositions, the iniergranular stresses during cooling may be strong enough that some of the microcracks tend to open up and lead to expansion during cooling. The difference in these shrinkages is very pronounced when CS-25 and CS-37.5 are compared. CS-25 has the larger anisotropy compared to CS-37.5, hence, the hysteresis as well as intergranular stresses are very large for CS-25. Accordingly, the "knee" at $150^{\circ} \mathrm{C}$ is also very pronounced for CS-25 as compared to CS-37.5 (see Figs. 24 and 25). Further investigation of the variation in the measured bulk linear thermal expansion when comparing measurements made on as sintered specimens to measurements made on thermally cycled specimens will be discussed in the next two sections.

In addition to the above discussed, a systematic literature search was carried out and all the thermal expansion data (bulk as well as axial thermal expansion for various compositions) have been compiled. This data is being maintained at LoTEC as a Microsoft Word file formatted for Macintosh and is available upon request.

Microstructural Considerations. Preliminary SEM examinations were carried out on fracture surfaces of flexure tested specimens of three CSX compositions viz. CS-25, 
CS-37.5, and CS-50 and one BSX composition - BS-25. The fracture mode in each of these compositions was generally transgranular. The fracture surface of the BS-25 specimen revealed very little micro-cracking which is consistent with the low thermal expansion anisotropy of this material. On the other hand, from the CSX samples the following was observed; more internal cracking (micro-cracks) in the CS-25 material with lesser amounts in CS-37.5 and very little in the CS-50. These observations confirm that the anisotropic compositions CS-25 and CS-37.5 are associated with microcracking behavior. Such microcracks likely formed during cooling of the sintered specimens to room temperature. Microcracking in the anisotropic materials (CS-25, CS-37.5 etc.) also explains their much lower fracture strengths as compared to the isotropic ones (CS-50, BS-25 etc.).

To examine further the microcracking behavior during thermal cycling, fracture surfaces of selected isotropic - BS-25 and CS-50 - and anisotropic - BS-0, BS-50 and CS25 - flexure specimens that were either as-sintered or thermally-cycled (up to 250 cycles at $1250^{\circ} \mathrm{C}$ ) were observed using scanning electron microscopy (SEM). SEM was used to evaluate structural changes in the various compositions due to thermal cycling to $1250^{\circ} \mathrm{C}$ in a room air environment. The thermal cycling process consisted of placing the fractured bars in crucibles made from that [NZP] composition and placing the crucibles in a furnace, and heating and cooling according to the following schedule:

R.T.

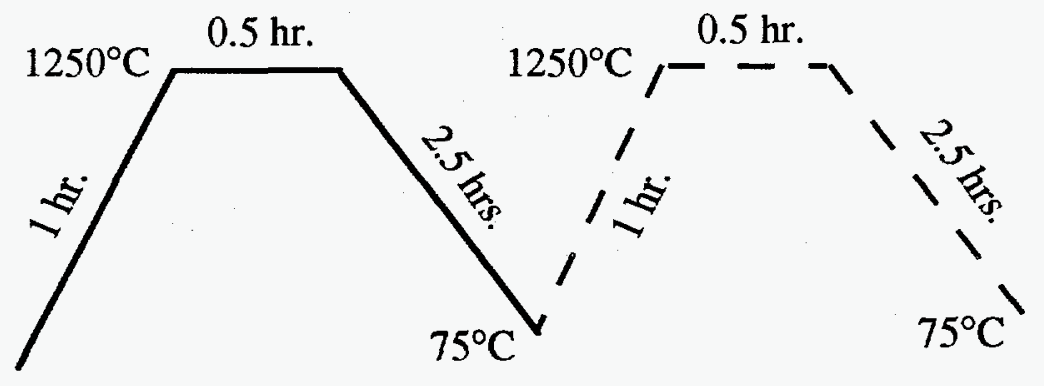

Figures 28 to 32 compare the microstructure (morphology) of the as-sintered specimens with the specimens cycled 250 times for the studied compositions. In the BSX series, there are two anisotropic compositions - BS-0 and BS-50 (Figs. 28, 30) - with either positive or negative bulk thermal expansion, respectively, and one isotropic composition - BS-25 (Fig. 29) - with a very low positive bulk thermal expansion. Evidence of microcracking is seen in the anisotropic compositions, both in the as-sintered and thermally cycled condition. This microcracking accounts for the low mechanical 

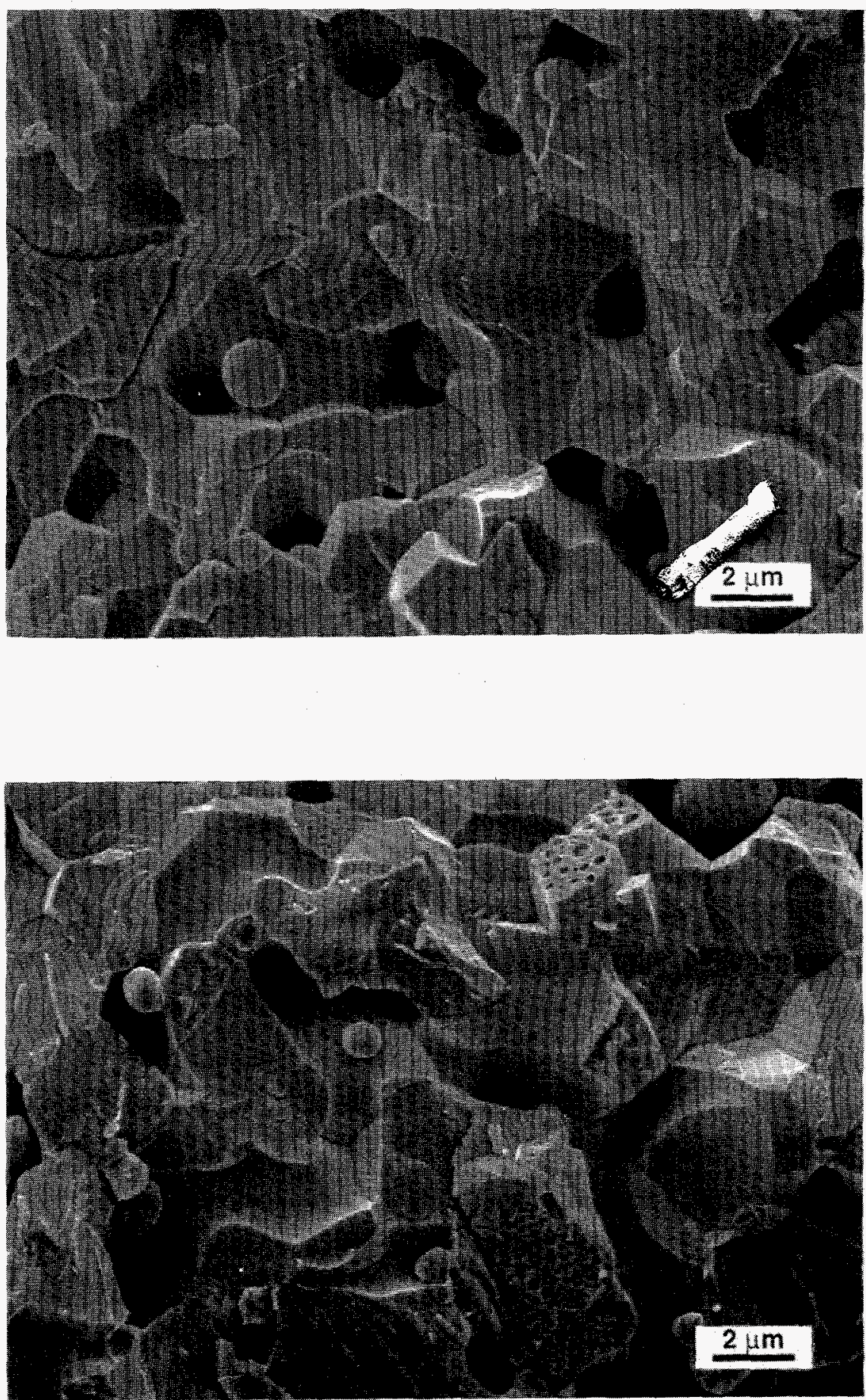

Figure 28. SEM fracture surface microstructures of (a) as-sintered and (b) thermally cycled $\left(250\right.$ cycles to $\left.1250^{\circ} \mathrm{C}\right) \mathrm{BS}-0$ specimens. 

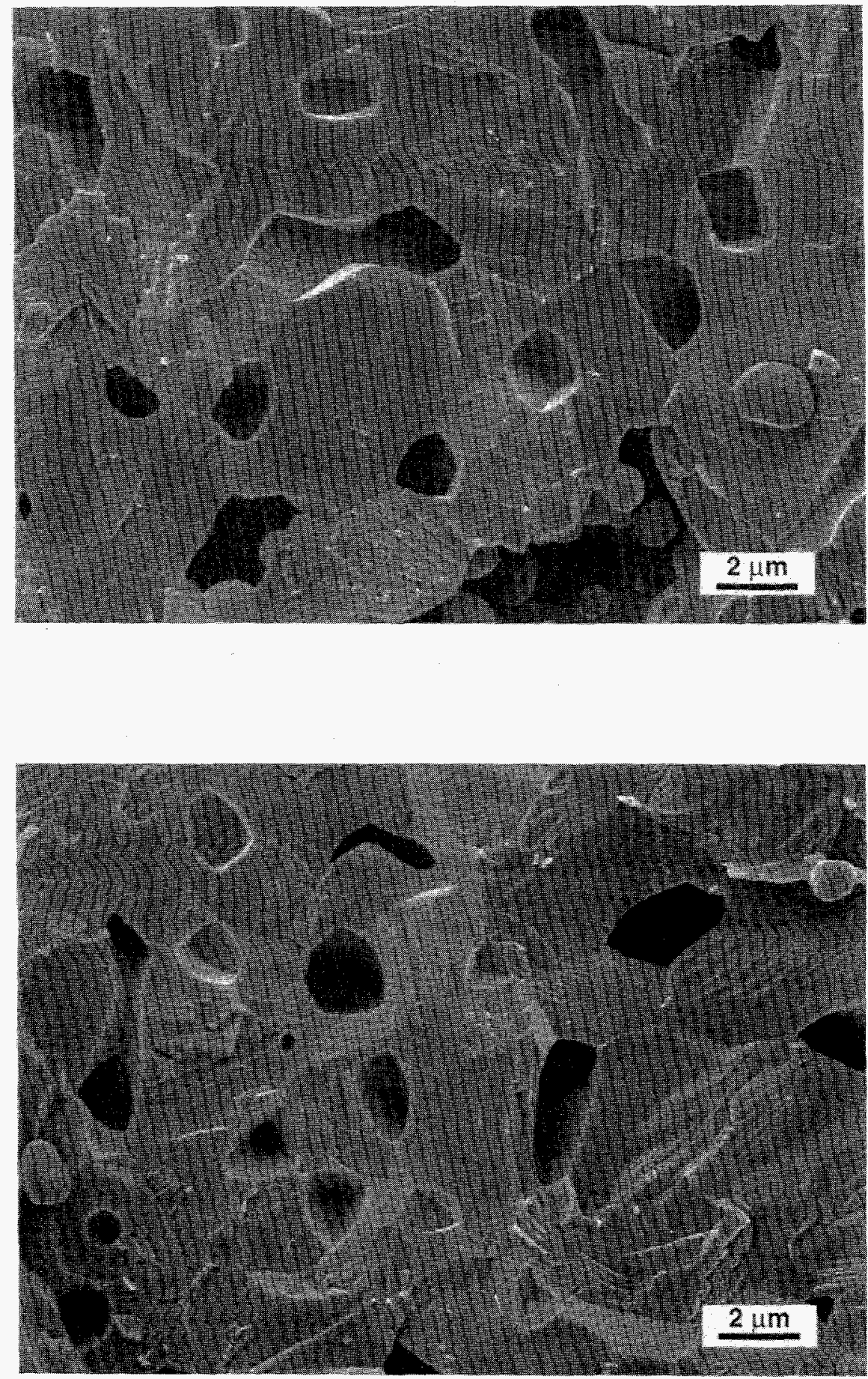

Figure 29. SEM fracture surface microstructures of (a) as-sintered and (b) thermally cycled $\left(250\right.$ cycles to $\left.1250^{\circ} \mathrm{C}\right) \mathrm{BS}-25$ specimens. 

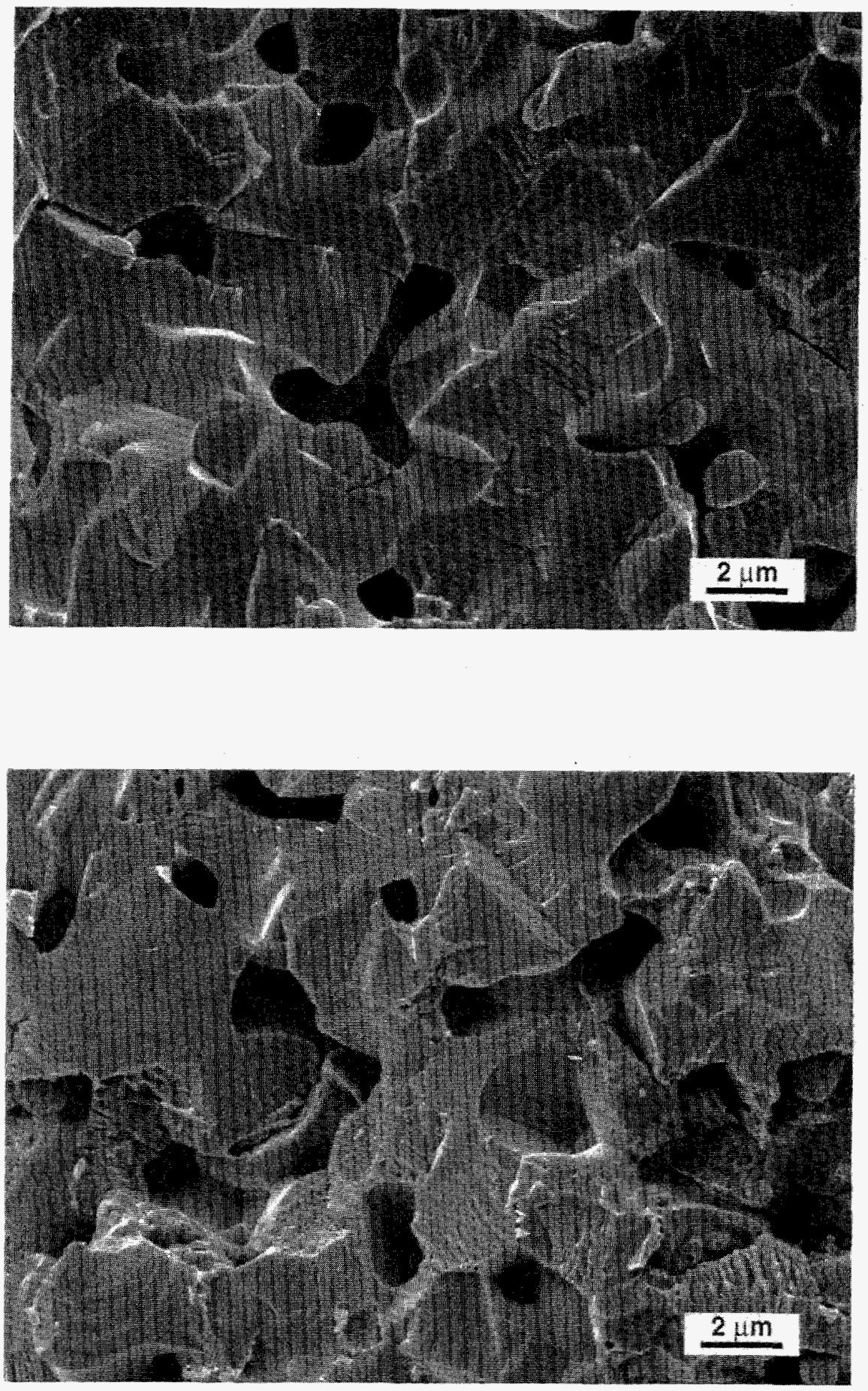

Figure 30. SEM fracture surface microstructures of (a) as-sintered and (b) thermally cycled $\left(250\right.$ cycles to $\left.1250^{\circ} \mathrm{C}\right) \mathrm{BS}-50$ specimens. 

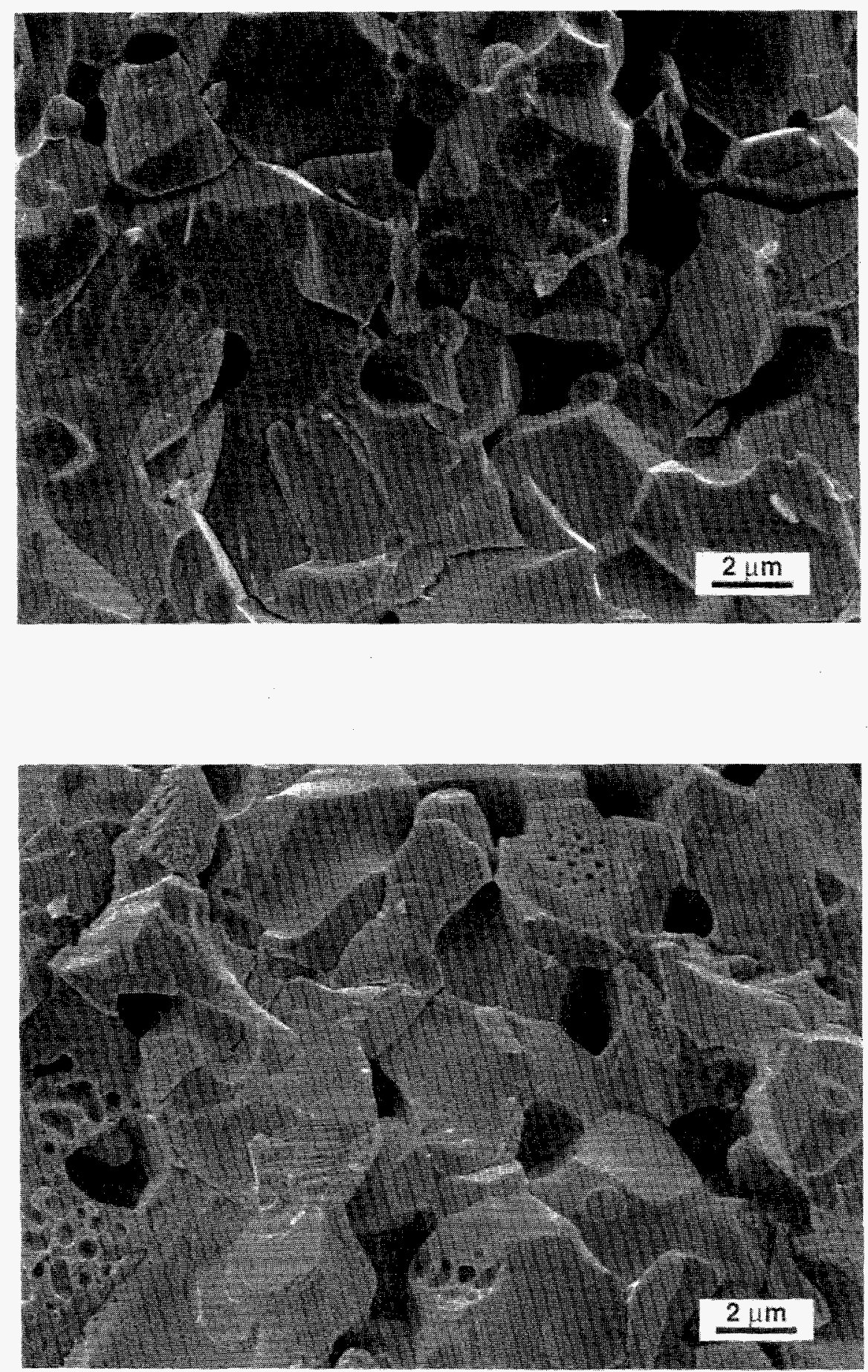

Figure 31. SEM fracture surface microstructures of (a) as-sintered and (b) thermally cycled $\left(250\right.$ cycles to $\left.1250^{\circ} \mathrm{C}\right) \mathrm{CS}-25$ specimens. 

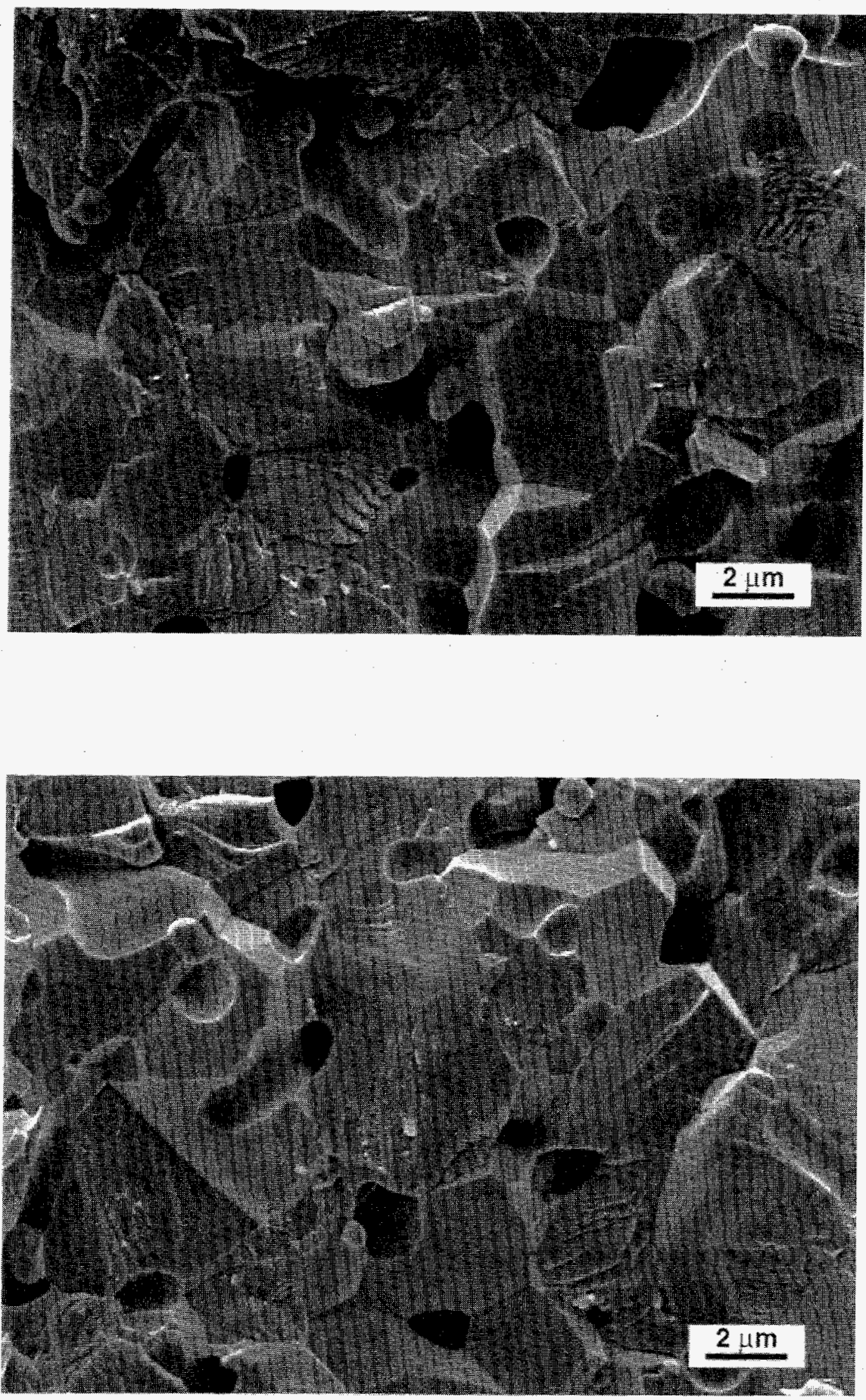

Figure 32. SEM fracture surface microstructures of (a) as-sintered and (b) thermally cycled $\left(250\right.$ cycles to $\left.1250^{\circ} \mathrm{C}\right) \mathrm{CS}-50$ specimens. 
strengths of the anisotropic compositions, discussed earlier in this report. There is little evidence of microcracking in the BS-25 specimen even after 250 cycles to $1250^{\circ} \mathrm{C}$. The observed porosity is consistent with the $85-90 \%$ theoretically dense specimens. An unexpected but significant feature of the microstructures is the fine porosity (cavitation) developed in the anisotropic compositions, BS-0 and BS-50, when subjected to thermal cycling. It is believed that this porosity, which has a similar appearance to that found in tensile creep specimens, is due to the anisotropic axial thermal expansion and the internal stresses developed between individual grains during thermal cycling. However, cavitation is not evident in the BS-25 specimen.

The microstructures of the CSX series specimens yielded results similar to those of the BSX compositions (see Figs. 31 and 32). Again, microcracking and cavity formation were found in the anisotropic CS-25 material while there was no evidence of microcracking or cavity formation in the isotropic CS-50 composition.

Environmental Effects (Moisture, Temperature) : As stated before there was substantial variation in bulk thermal expansion of anisotropic, microcracked compositions. Upon cooling from the sintering temperature, the ceramic microcracks due to the stresses associated with the anisotropic axial thermal expansion of the individual ceramic grains. The microcracks are further opened by the absorption of moisture from either the air or when the ceramic is ground into test specimens in a manner similar to stress corrosion cracking observed in other ceramic materials. When the test specimen is reheated during the thermal expansion measurement the absorbed moisture is driven off and the microcracks close. Further heating promotes microcrack healing. Taken together this explains the apparent lower bulk thermal expansion obtained for the as sintered and ground specimens. If the subsequent thermal expansion measurements are made shortly after the heat treatment, before any substantial amount of moisture is reabsorbed, consistent results should be obtained. This view finds corroboration in the almost identical expansion curves of Figure 24 for an anisotropic material, such as CS-25, subjected to 1 and 250 thermal cycles between room temperature and $1250^{\circ} \mathrm{C}$.

To test the hypothesis that it is moisture that promotes crack opening, the following experiments were performed. An anisotropic (CS-25) specimen was heated and cooled in a dilatometer surrounded by an inert (helium) atmosphere. When the specimen reached an equilibrium length during cooling (close to room temperature), the helium atmosphere 
was displaced by dry air. Next, air with controlled relative humidity was allowed to surround the specimen. With each increase in relative humidity there was a corresponding increase in specimen length. Finally, the dilatometer was carefully opened and water was dripped on to the specimen; this resulted in a sharp increase in the specimen length. The results of this experiment are shown in Fig. 33.

The above said experiment was performed using an isotropic behavior (CS-50) specimen. Since the isotropic material returns to its original length by the time it cools down to room temperature and there are not any microcracks present to open up, moisture had virtually no effect on the CS-50 specimen. To determine if the other anisotropic compositions like BS-0 and BS-50 exhibited similar behavior as that of the CS-25 specimen, they were heated and cooled in the dilatometer, which was then followed by controlled application of drops of water. The results obtained for all the anisotropic materials - BS-0, BS-50 and CS-25 - are shown in Fig. 34 and contrasted with that for isotropic BS-25. Figures 35(a) and (b) (results derived from verisimilar experiments) provide a closer look into the moisture-assisted microcracking behavior of the BS-0 material.

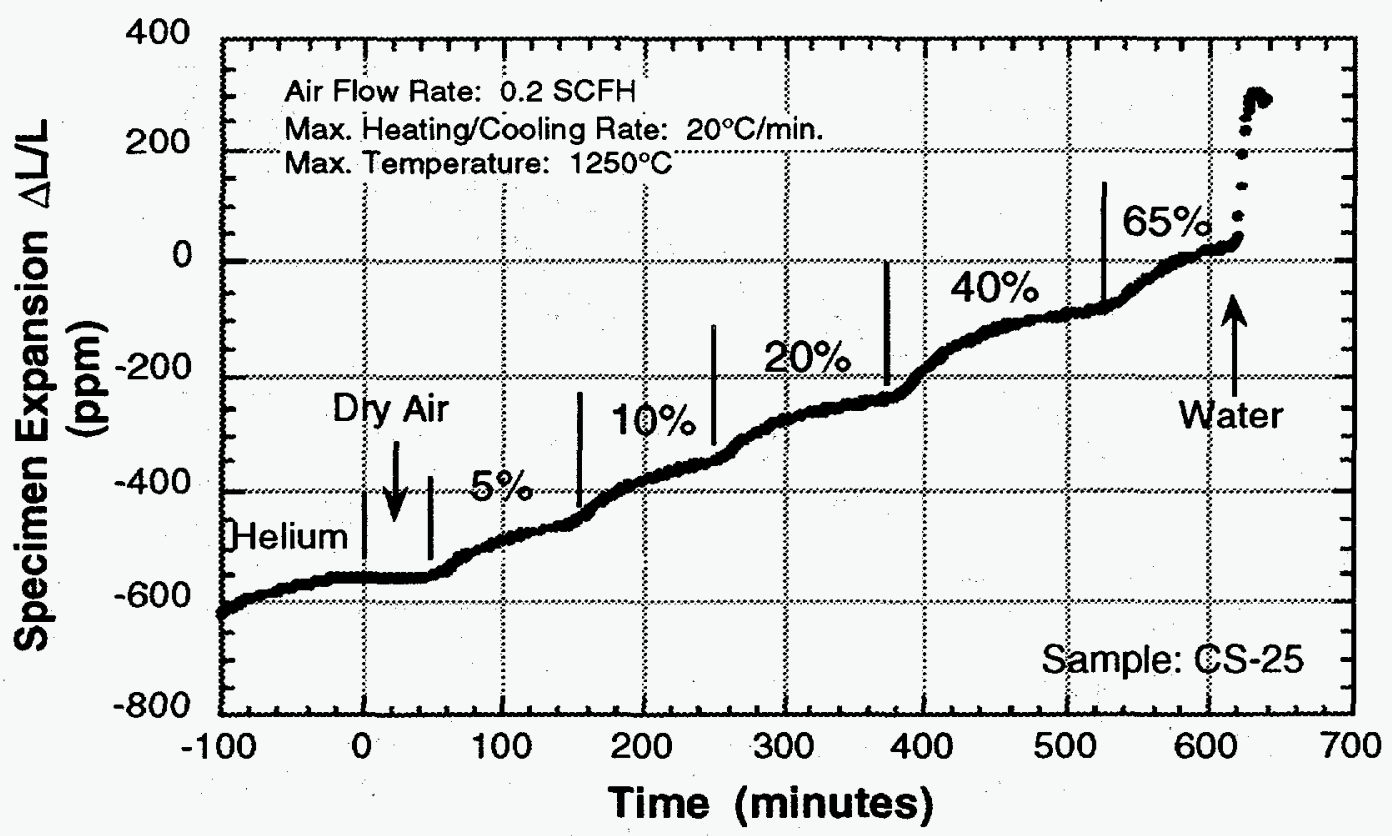

Figure 33. Moisture-assisted microcracking of anisotropic composition CS-25. 


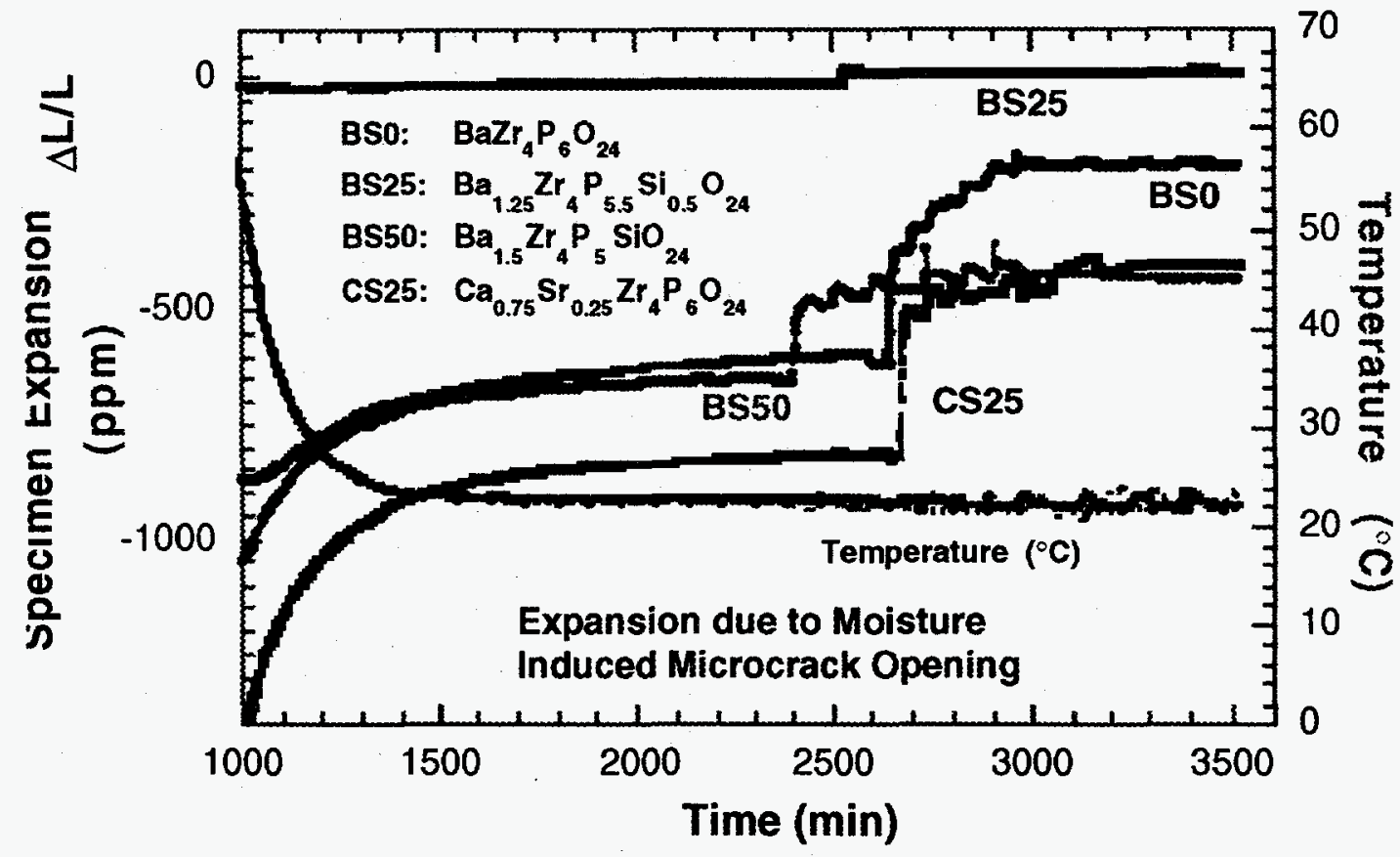

Figure 34. Environmental Effect on Room Temperature Expansion of various NZP compositions.

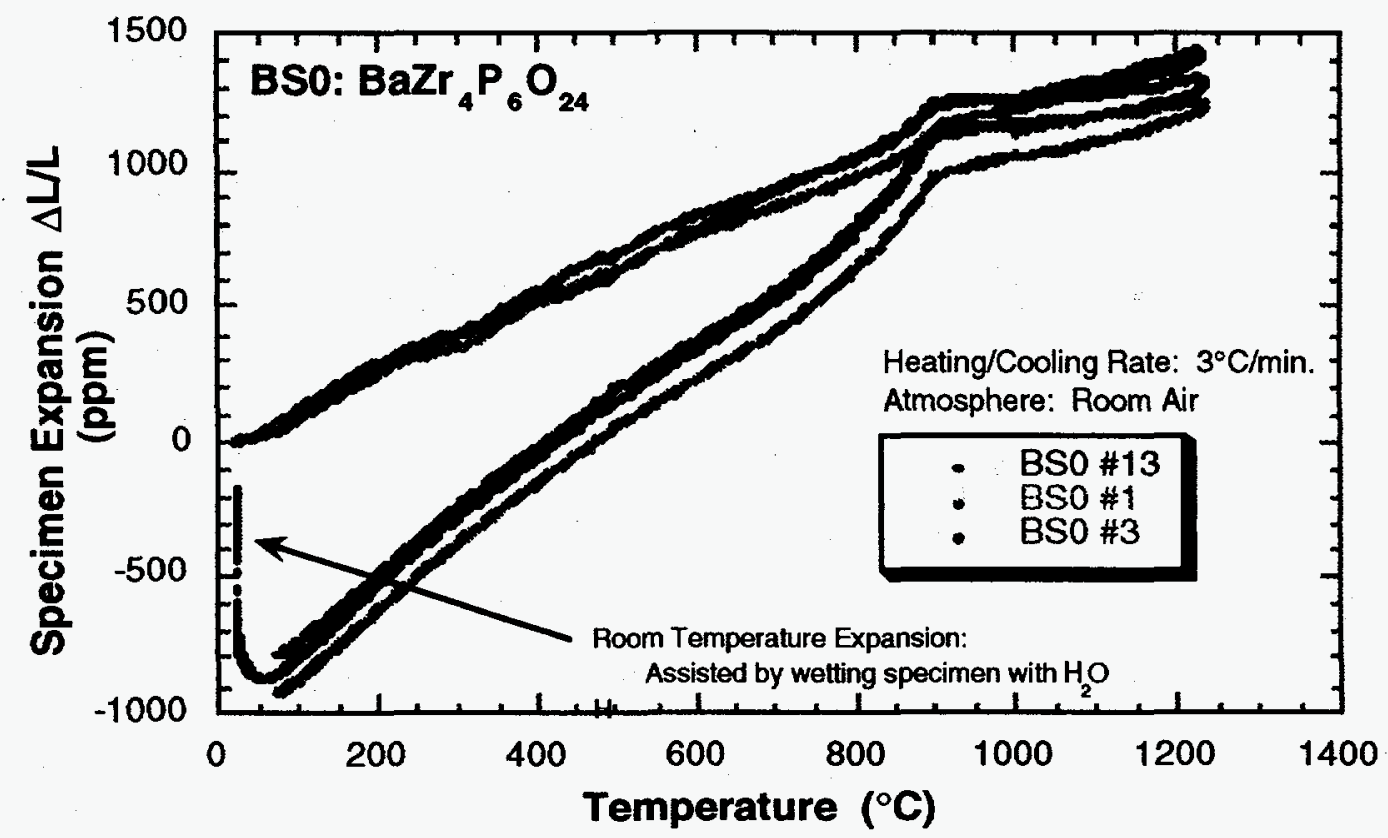

Figure 35(a). Environmental Effect on Room Temperature Expansion of BS-0. 


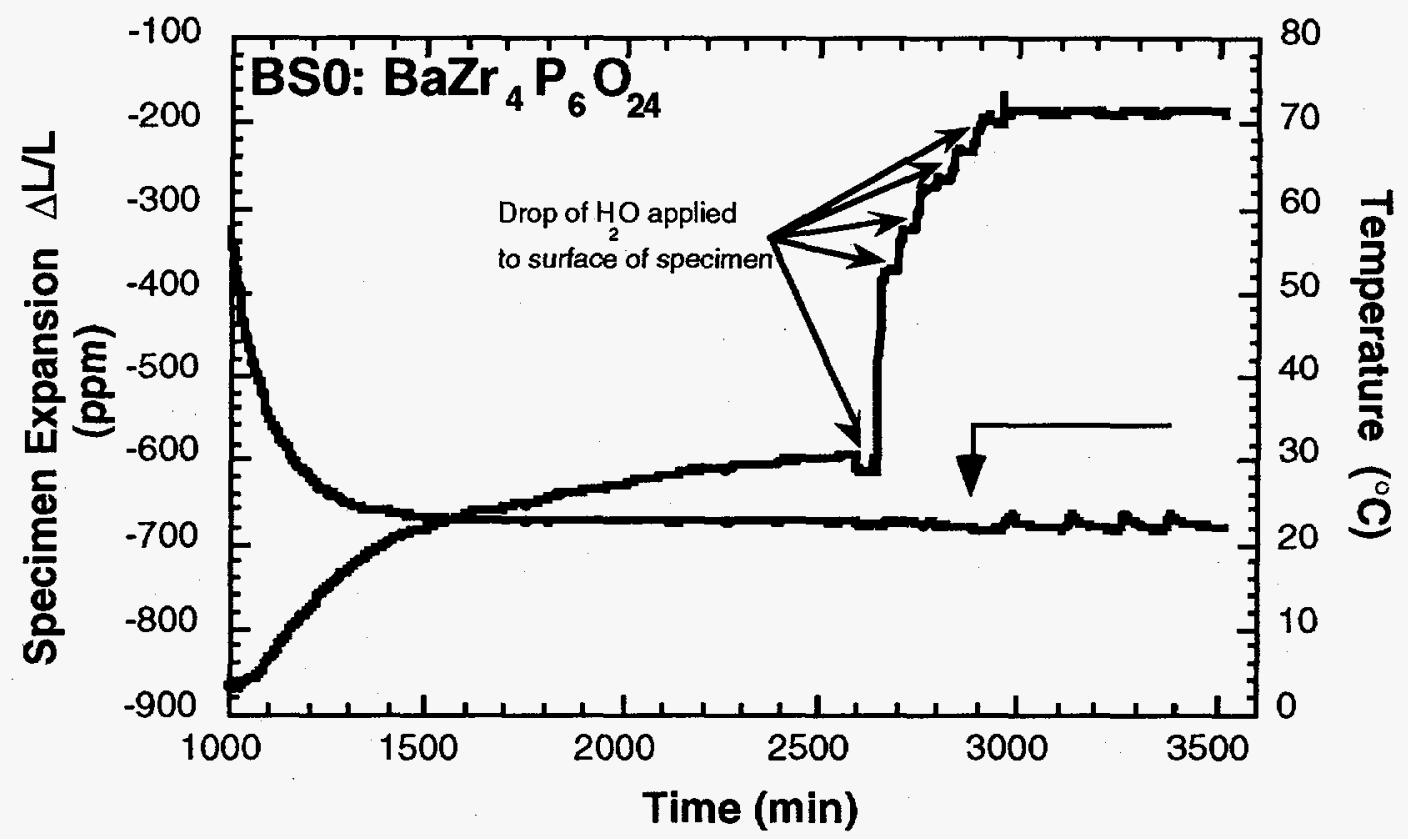

Figure 35(b). Environmental Effect on Room Temperature Expansion of BS-0.

To determine if there was any chemical change (hydration) associated with the absorption of water, powder X-Ray diffraction analysis was performed. A sintered test specimen was crushed to form a fine powder. A portion of this powder was heated to $1000^{\circ} \mathrm{C}$ to drive of any moisture present and then $\mathrm{x}$-rayed. A similar amount of powder was mixed with water, allowed to dry and then $\mathrm{x}$-rayed. The powder diffraction patterns for the two samples are shown in Fig. 36. It was not possible to detect any secondary phases by this analytical method.

\section{Thermal Stability}

Long-term thermal stability of the BSX and CSX compositions were assessed by cycling samples between room temperature and $1250^{\circ} \mathrm{C}$ for up to 250 times and measuring weight changes, especially weight loss due to reduction. All compositions tested showed very little weight loss indicating good thermal stability. However, the anisotropic materials revealed slightly greater losses than the isotropic ones (BS-25 and CS-50) after the first thermal cycle. Further cycling (up to 250 cycles) resulted in less than 0.05 percent weight loss in all compositions. The greater weight loss of the anisotropic samples after the first cycle could be attributed to the loss of moisture, 


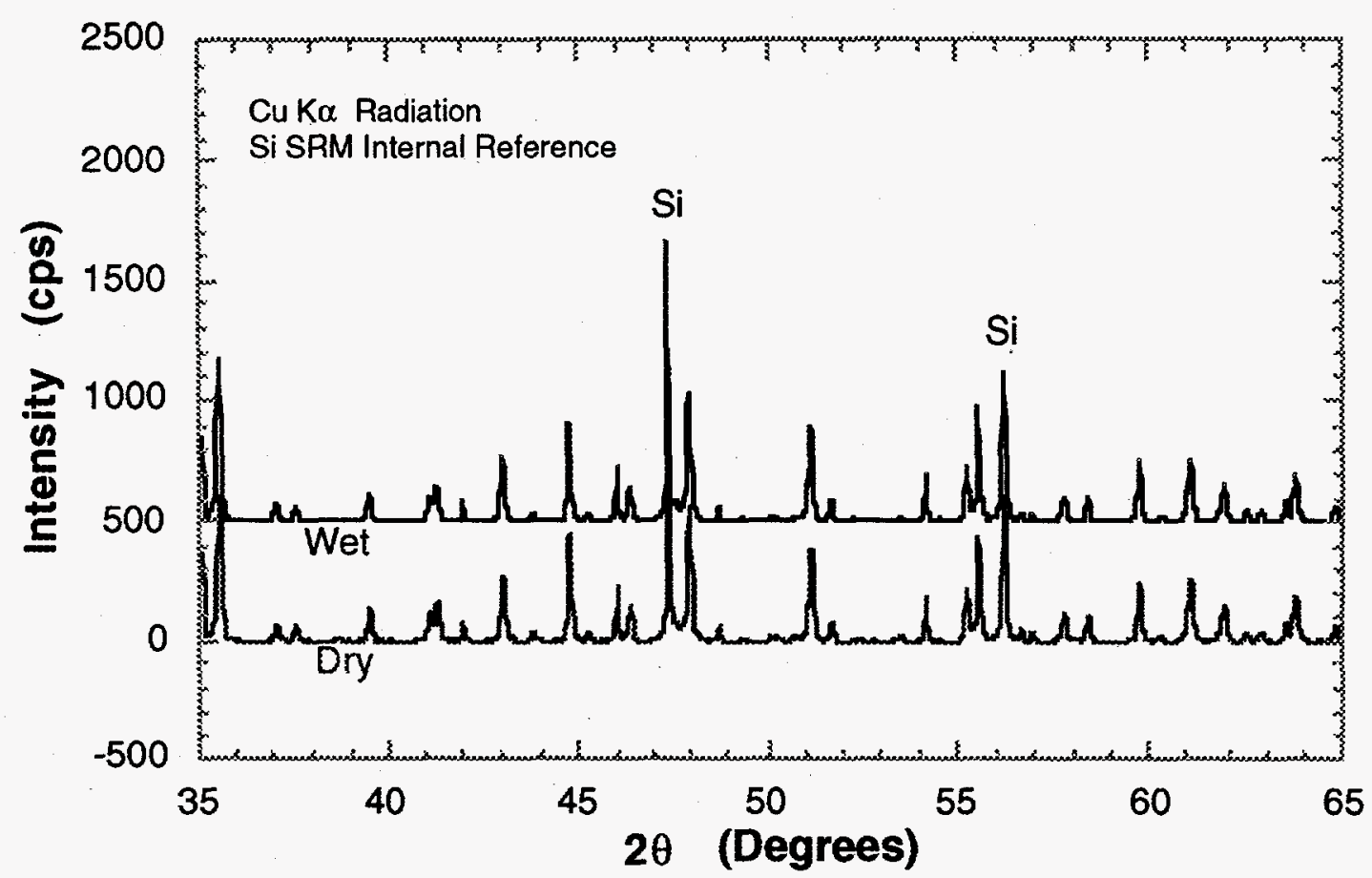

Figure 36. Powder X-ray diffraction patterns of "As-Sintered" and "Moisture-treated" CS-25 material.

organic solvents (absorbed during specimen grinding process) present in the microcracks, and any low volatile phosphates etc. Figure 37 depicts normalized weight loss as a function of the number of cycles. The weight loss has been normalized to the weight of the specimens after 1 cycle to $1250^{\circ} \mathrm{C}$. In future work, $\mathrm{X}$-ray analysis will be conducted to ensure presence of the original NZP phases after thermal cycling.

\section{Thermal Shock Resistance}

Thermal shock tests were conducted on the BSX compositions in two ways: first, by quenching the samples from progressively higher temperatures into a bath of liquid nitrogen until the samples (macro) cracked; and second, by cyclically quenching BS-25 bar samples previously heated to $1250^{\circ} \mathrm{C}$ into water at $2^{\circ} \mathrm{C}$ for up to 50 cycles and measuring the residual strengths of the bars in four-point flexure.

The results of the first test are summarized in the bar plot of Figures 38 ( $\Delta \mathrm{T}$ in Fig. 38 represents the maximum temperature drop that could be survived). As expected, 

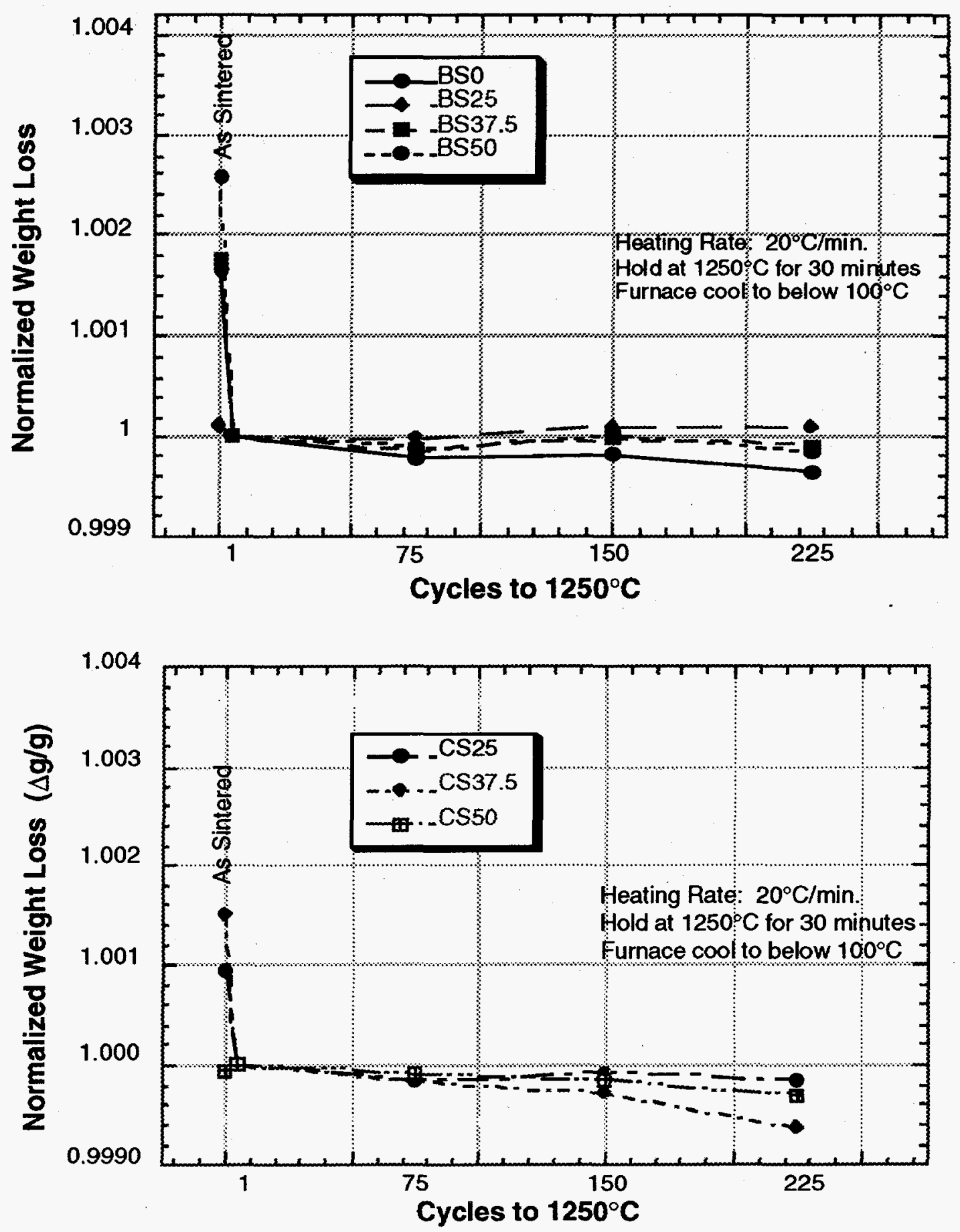

Figure 37 (a) \& (b). Normalized weight loss as a function of cycles to $1250^{\circ} \mathrm{C}$ for the (a) BSX and (b) CSX compositions. 


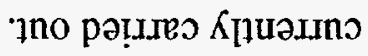

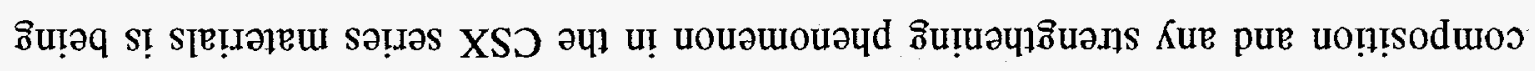

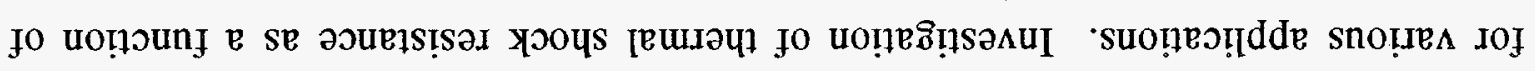

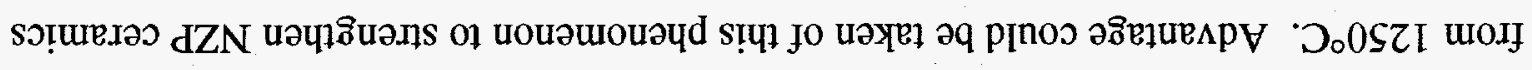

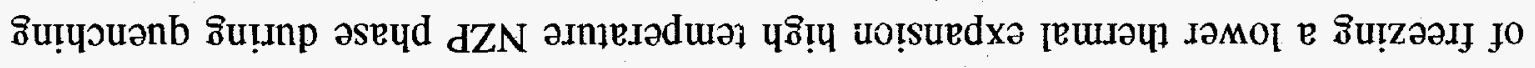

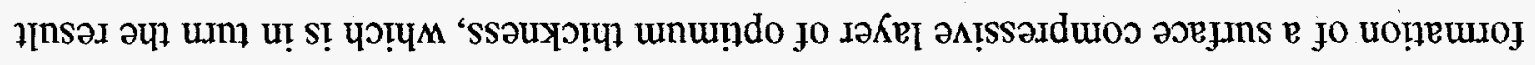

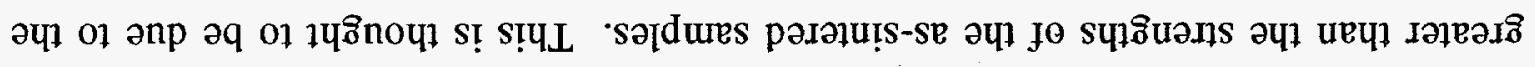

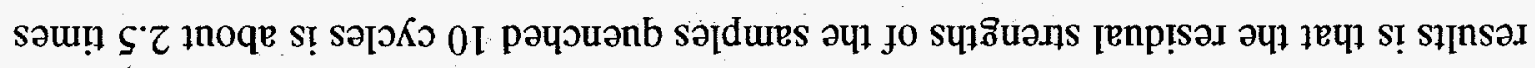

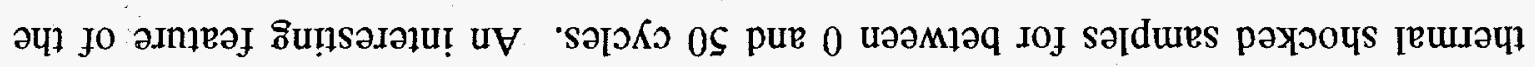

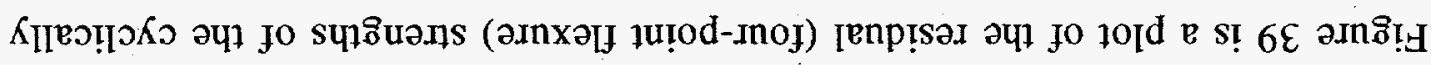

०М1 Јวч10 วน1

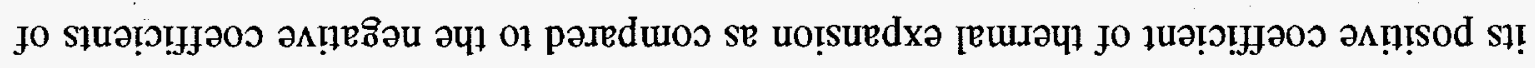

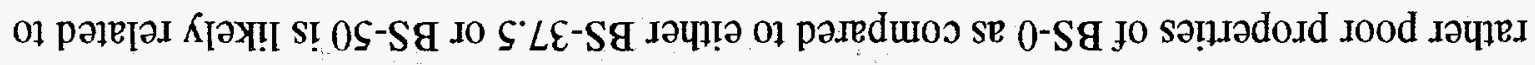

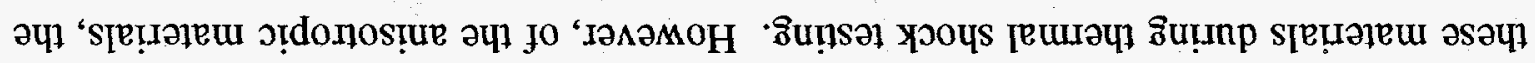

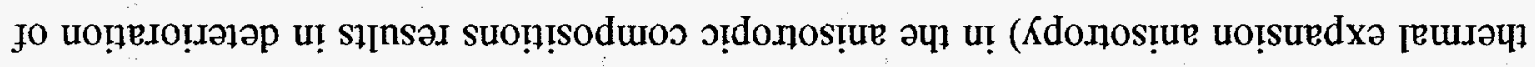

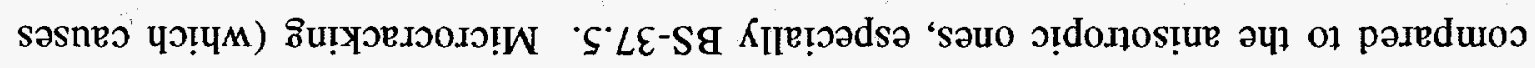

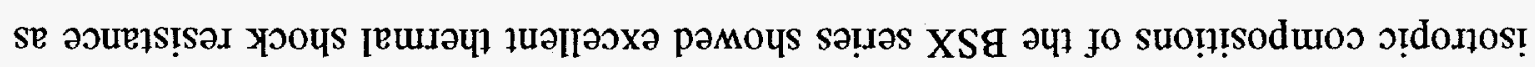

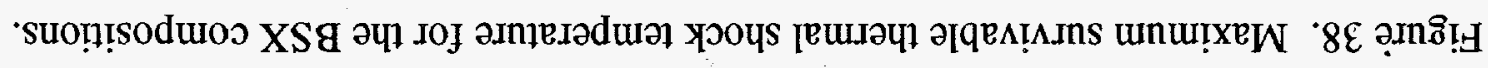

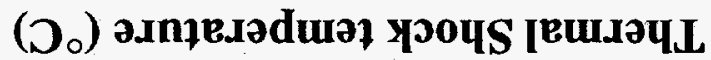

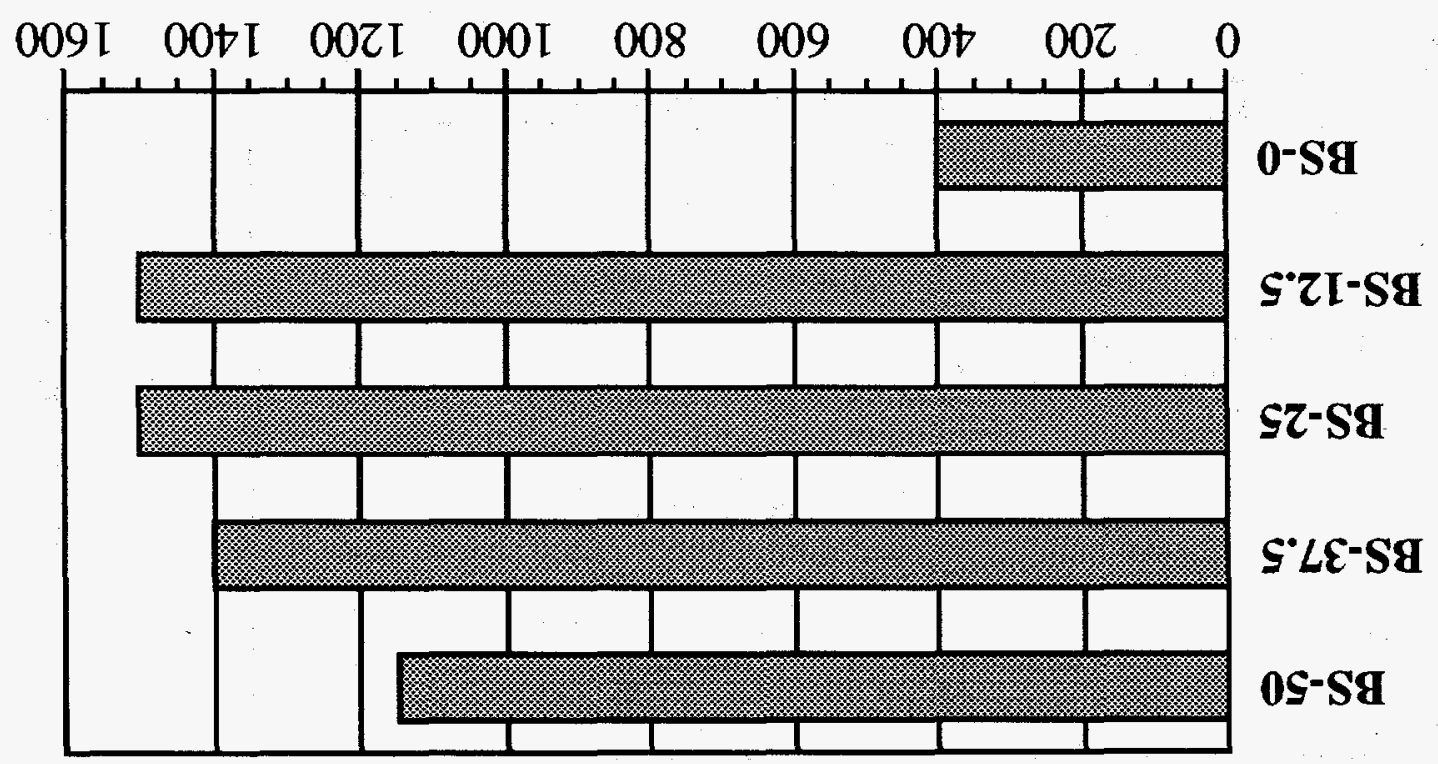




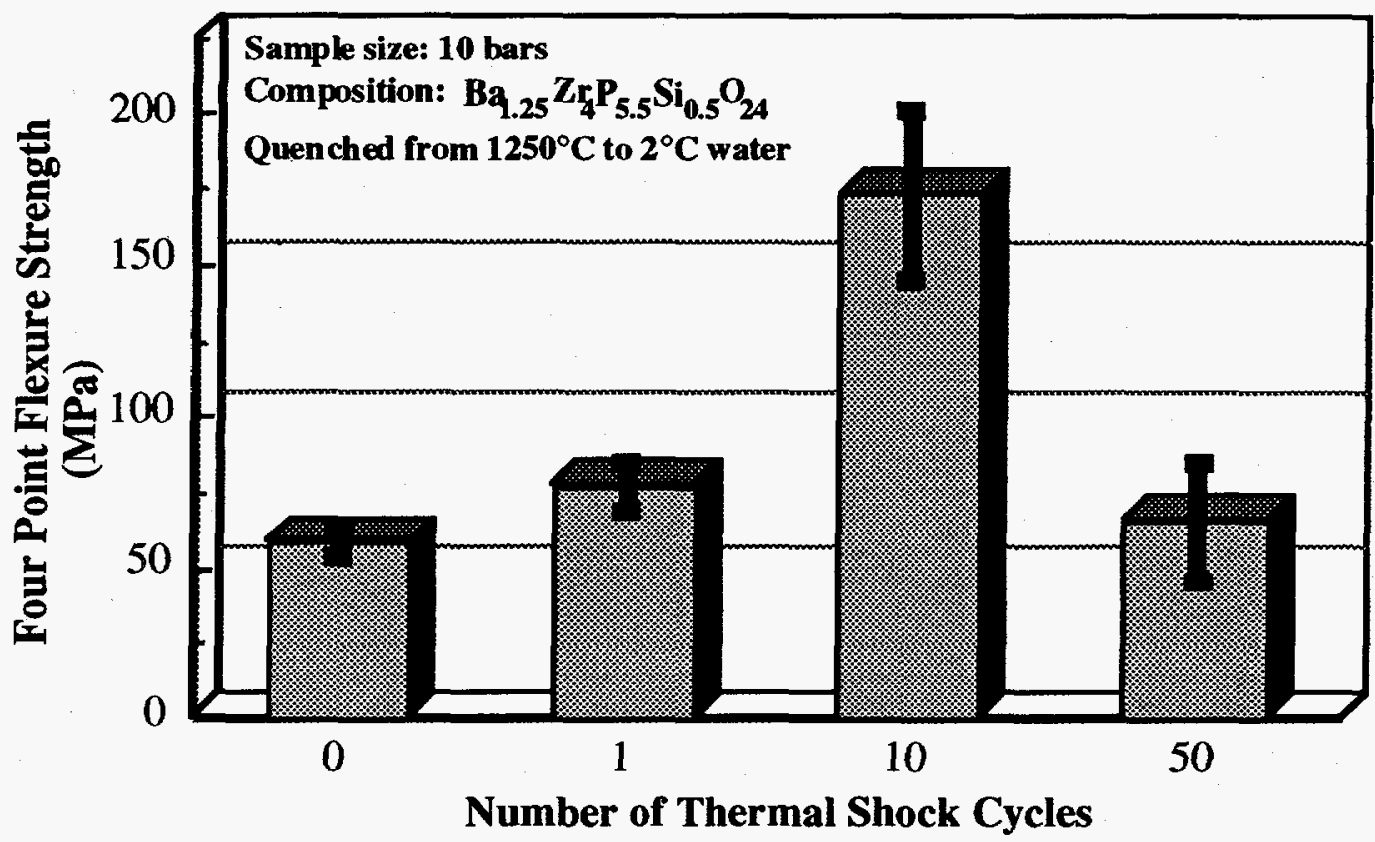

Figure 39. Residual flexure strengths of cyclically thermal shocked BSX specimens.

\section{High Temperature Elastic Modulus}

For this work, the BS-25 material alone was subjected to high temperature elastic modulus measurements during Phase I work. These measurements were performed using an ultrasonic measurement technique at Penn State University. In this procedure, a bar sample of the BS-25 ceramic was suspended in a furnace by two sapphire threads acting as ultrasonic waveguides, connected to two transducers, one acting as a source and the other as receiver. The temperature was raised slowly to $1325^{\circ} \mathrm{C}$ and the resonance frequency was noted at $100^{\circ} \mathrm{C}$ intervals. The Young's modulus was calculated from:

$$
E=\frac{0.94645 \mathrm{Cmf}^{2}}{W}
$$

In Equation (3), $\mathrm{C}$ is a constant that depends upon the Poisson's ratio, v, specimen thickness, $t$, and length, $\mathrm{l}$; and $\mathrm{m}$ is the mass; $\mathrm{f}$ is the flexural resonance frequency; and $\mathrm{W}$ is the width. Here the Poisson's ratio, $v$, was assumed to be 0.23 .

Figure 40 represents a plot of the elastic modulus of BS-25 as a function of temperature. It can be noted that the modulus is nearly the same at $1200^{\circ} \mathrm{C}$ as at room temperature. As seen in the figure, the Young's modulus increases with temperature due 


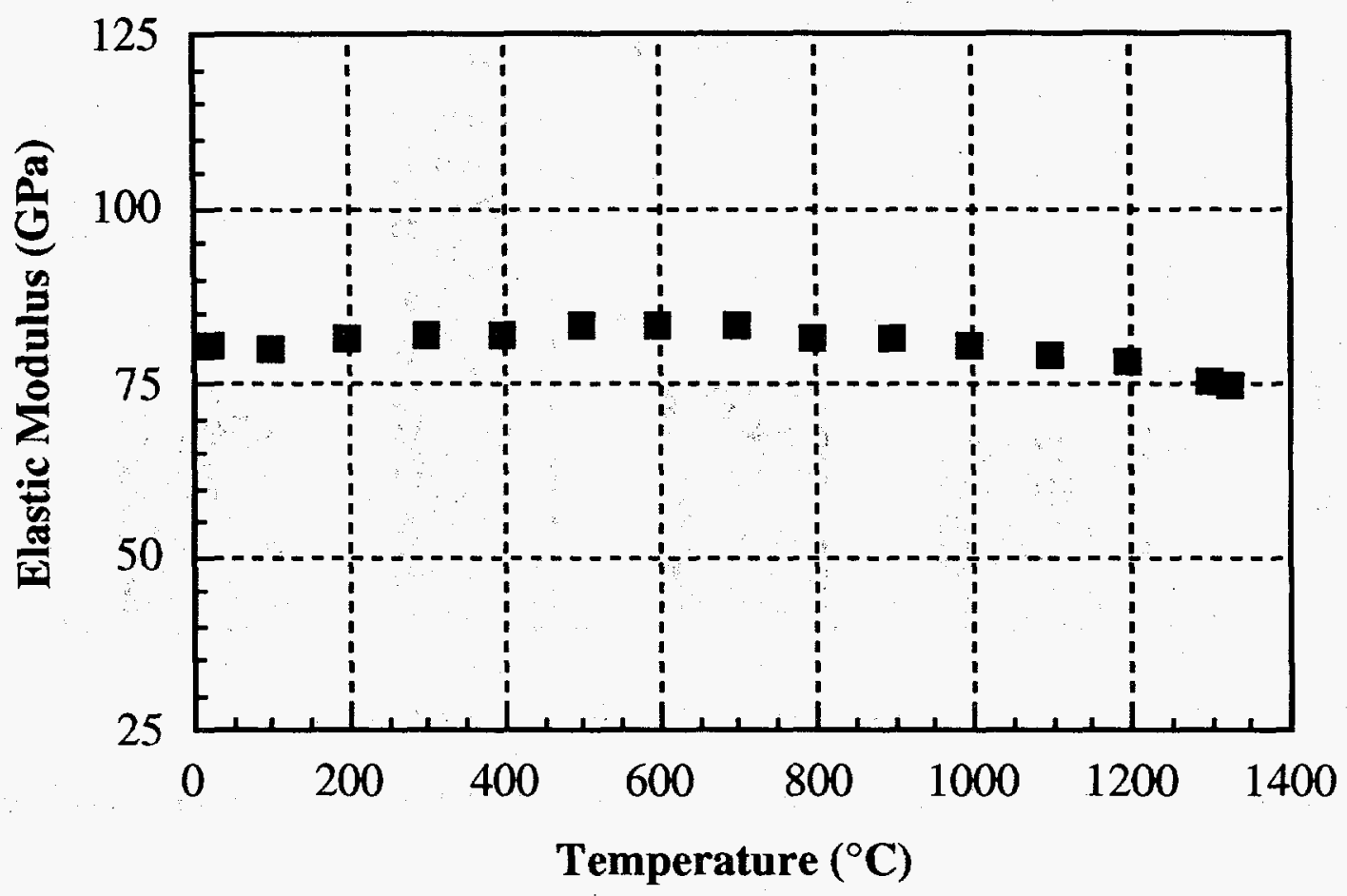

Figure 40. Elastic modulus of BS-25 as a function of temperature.

to the healing of microcracks, reaches a maximum between 500 and $700^{\circ} \mathrm{C}$ and then decreases as the temperature increases further. Measurements of high temperature elastic modulus of CS-50 and other materials have been planned for the Phase II part of this research.

\section{MATERIALS AND PROCESSES' DEVELOPMENT}

The materials and processes intended to be developed in this Phase I work included: (i) metal-NZP ceramic composites with the metal cast around the ceramic, (ii) alternative shape forming process such as pressure slip casiing and gel casting, (iii) ultrasonics-based ND flaw detection technique, (iv) new low thermal expansion NZP compositions, and (iv) acoustic emission based microcrack detection process. The former three tasks were carried out on site and the latter two at Penn State University. 
Molten Metal Casting Trials

One of the primary goals of this project is the demonstration of the ability to cast molten metal around a (NZP) type ceramic shape without causing damage to the ceramic or the solidified metal casting. Based on the results of characterization of the various NZP ceramic compositions, the mechanically and thermally superior BS-25 $\left(\mathrm{Ba}_{1.25} \mathrm{Zr}_{4} \mathrm{P}_{5.5} \mathrm{Si}_{0.5} \mathrm{O}_{24}\right)$ and $\mathrm{CS}-50\left(\mathrm{Ca}_{0.5} \mathrm{Sr}_{0.5} \mathrm{Zr}_{4} \mathrm{P}_{6} \mathrm{O}_{24}\right)$ materials were selected for the metal casting trials. These compositions have ultra-low and low coefficients of thermal expansion (the average CTE of $\mathrm{BS}-25$ from room temperature to $1000^{\circ} \mathrm{C}$ is $0.7 \times 10^{-6} /{ }^{\circ} \mathrm{C}$ and for CS-50 over this range is $1.9 \times 10^{-6} /{ }^{\circ} \mathrm{C}$.), respectively, and very low thermal expansion anisotropy. The ceramic test shapes were straight or $90^{\circ}$ - elbow tubes with an outside diameter of approximately $50 \mathrm{~mm}$, with a $5 \mathrm{~mm}$ wall thickness.

Initial metal casting trials with both the BS-25 and CS-50 ceramic tubes resulted in failure of the ceramic due to the large compressive stresses. These stresses were, in turn, created by the thermal expansion mismatch between the metal and the ceramic. As pointed out in an earlier section (Materials Requirement Analysis), finite element analysis of the metal casting process revealed large compressive stresses in the NZP ceramicmetal system. All these clearly demonstrated the need for reduced elastic modulus (increased strain to failure of the ceramic port liner) or providing a compliant layer to avoid large compressive stresses that would lead to the failure of the ceramic. To ensure that the ceramic survives the shrinkage stresses associated with the metal casting process, a test matrix approach was developed. Table 7 provides the details of this test matrix to improve the survivability of the ceramic during the metal casting.

Preliminary work on the lines of the summary in Table 7 involved the introduction of a compliant layer between the metal (cast iron or aluminum) and the ceramic (BS-25). The compliant layer was designed to absorb the thermal stresses (generated during cooling from a high temperature) associated with the thermal expansion mismatch between the ceramic and the metal. All of the casting trials involving the compliant layer were successful, demonstrating the ability to cast the ceramic in place. A crude test was performed to determine the impact resistance of the ceramic within the metal casting. The metal/ceramic composite tube was dropped repeatedly from approximately 2 meters height on to a concrete block. The ceramic tube was checked for cracks, chipping, and any loosening from the surrounding metal. There was no apparent damage to the ceramic, which is indicative of the beneficial effects of the compliant layer. 
Table 7. Planned tests for improving NZP-ceramic survivability during the metal casting process.

\begin{tabular}{|c|c|c|}
\hline Variables & Methods/Techniques & Comments \\
\hline I. Elastic Modulus & $\begin{array}{l}\text { a. Introduce porosity } \\
\text { Acicular } \\
\text { Plate shaped } \\
\text { b. Reduce Sintering Temp. } \\
\text { c. Microcracking } \\
\mathrm{BaZr}_{4} \mathrm{P}_{6} \mathrm{O}_{24} \\
\mathrm{Ca}_{0.75} \mathrm{Sr}_{0.25} \mathrm{Zr}_{4} \mathrm{P}_{6} \mathrm{O}_{24} \\
\mathrm{Ba}_{1.5} \mathrm{Zr}_{4} \mathrm{P}_{5} \mathrm{SiO}_{24}\end{array}$ & $\begin{array}{l}\text { Will reduce modulus however, } \\
\text { will also reduce the strength }\end{array}$ \\
\hline II. Compliant Layer & $\begin{array}{l}\text { a. Porous coatings } \\
\text { b. Thermal spray coatings } \\
\text { c. Hollow spheres } \\
\text { d. Misc. compliant coatings }\end{array}$ & $\begin{array}{l}\text { Could increase cost, possible } \\
\text { rattling during high operating } \\
\text { temperature }\end{array}$ \\
\hline III. Higher CTE & $\begin{array}{l}\mathrm{BaZr}_{4} \mathrm{P}_{6} \mathrm{O}_{24} \\
\mathrm{SrZr}_{4} \mathrm{P}_{6} \mathrm{O}_{24} \\
\mathrm{Ca}_{0.5} \mathrm{Sr}_{0.5 \mathrm{Zr}_{4} \mathrm{P}_{6} \mathrm{O}_{24}}\end{array}$ & $\begin{array}{l}\text { May not survive thermal shock } \\
\text { associated with metal casting }\end{array}$ \\
\hline
\end{tabular}


Next, X-ray computer tomography was performed to examine the metal-compliant layer and ceramic-compliant layer interfaces. The interfaces were found to be intact in most cases as is evident from Figure 41 which is a X-ray computer tomography based picture of the interface. However, in a few cases where there was direct contact between the metal and the ceramic tube (a void in the compliant layer) a small crack had developed in the ceramic (see arrow in Figure 42). The cracks were approximately 0.05 to $0.1 \mathrm{~mm}$ wide and extended up to $5 \mathrm{~mm}$ in length from the metal-ceramic contact point. This observation suggests that uniformity of the compliant layer is critical to maintain interface integrity and strength. It is also expected that the thickness of the compliant layer will influence the overall performance of the part in actual service. Work is continuing in the area of metal casting around the ceramic tube and subsequent evaluation of the composite tube in field testing. Refinements are being made and tested to improve the casting process and better understand the requirements of the compliant layer.

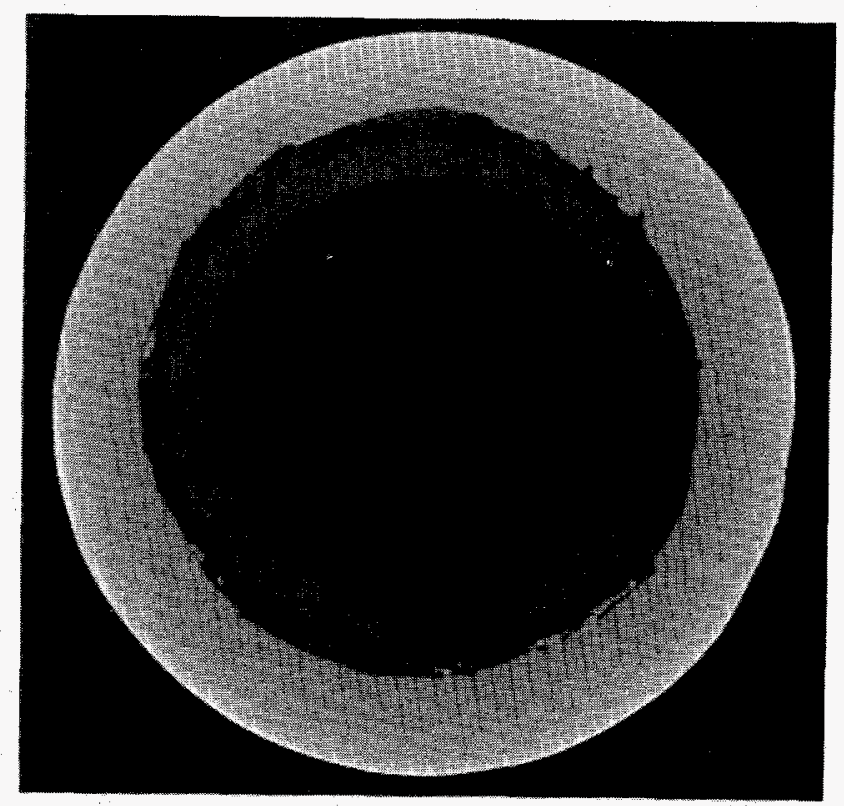

Figure 41. X-Ray computer tomography picture of the metal-ceramic composite tube with compliant layer in between. 


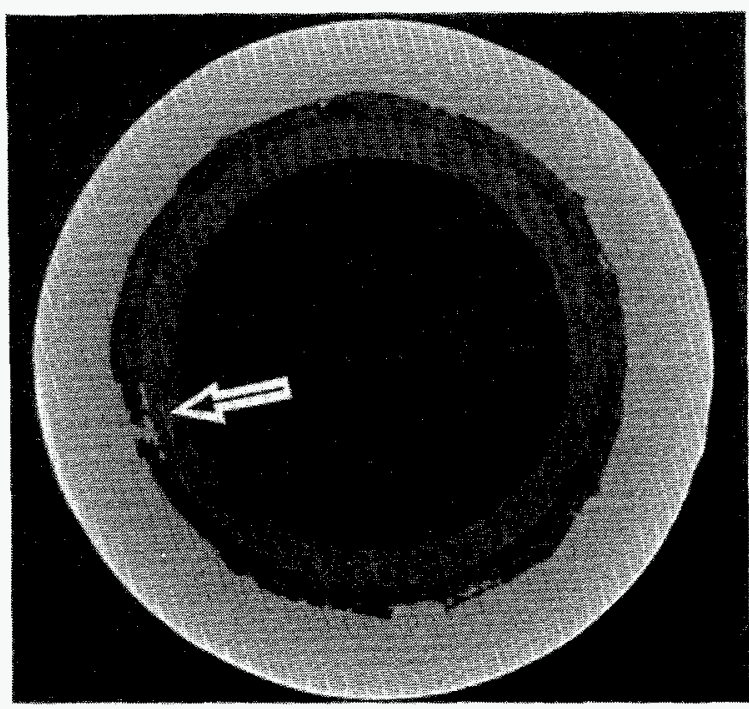

Figure 42. X-Ray computer tomography picture of the metal-ceramic composite tube showing crack (arrow) in the ceramic.

\section{Pressure Slip Casting}

An alternative shape forming process, pressure slip casting, was investigated. A large batch $(20 \mathrm{~kg})$ of $\mathrm{BS}-25\left(\mathrm{Ba}_{1.25} \mathrm{Zr}_{4} \mathrm{P}_{5.50} \mathrm{Si}_{0.50} \mathrm{O}_{24}\right)$ powders was synthesized and ball milled for eight hours with the appropriate binder and dispersant system, and the slip was prepared for pressure slip casting. The schematic diagram of the pressure slip casting set-up is shown in Figure 43. A series of plaster molds were fabricated for the purpose of pressure casting. Slip was poured into the molds and pressure exerted using compressed air. Wall thicknesses (dependent variable) of the cast bodies were measured as function of time and pressure (independent variables). Figures 44 and 45 show the effect of time and pressure on the wall thickness of the cast ceramic.

The results of pressure slip casting studies indicate that increased pressure leads to rapid build-up of the wall. For example, with an air pressure of $80 \mathrm{psi}$, the wall thickness builds up to 0.24 " within two minutes as compared to a $0.25^{\prime \prime}$ wall thickness upon holding the slip for one hour without applying any pressure. This drastic improvement in the casting rates would provide the necessary rapid manufacturing capabilities and allow cost effective manufacturing of NZP ceramics. Further optimization of the pressure slip casting process parameters (as with the regular process) such as binders, dispersants and $\mathrm{pH}$ is likely to yield finished products with the best possible properties. 


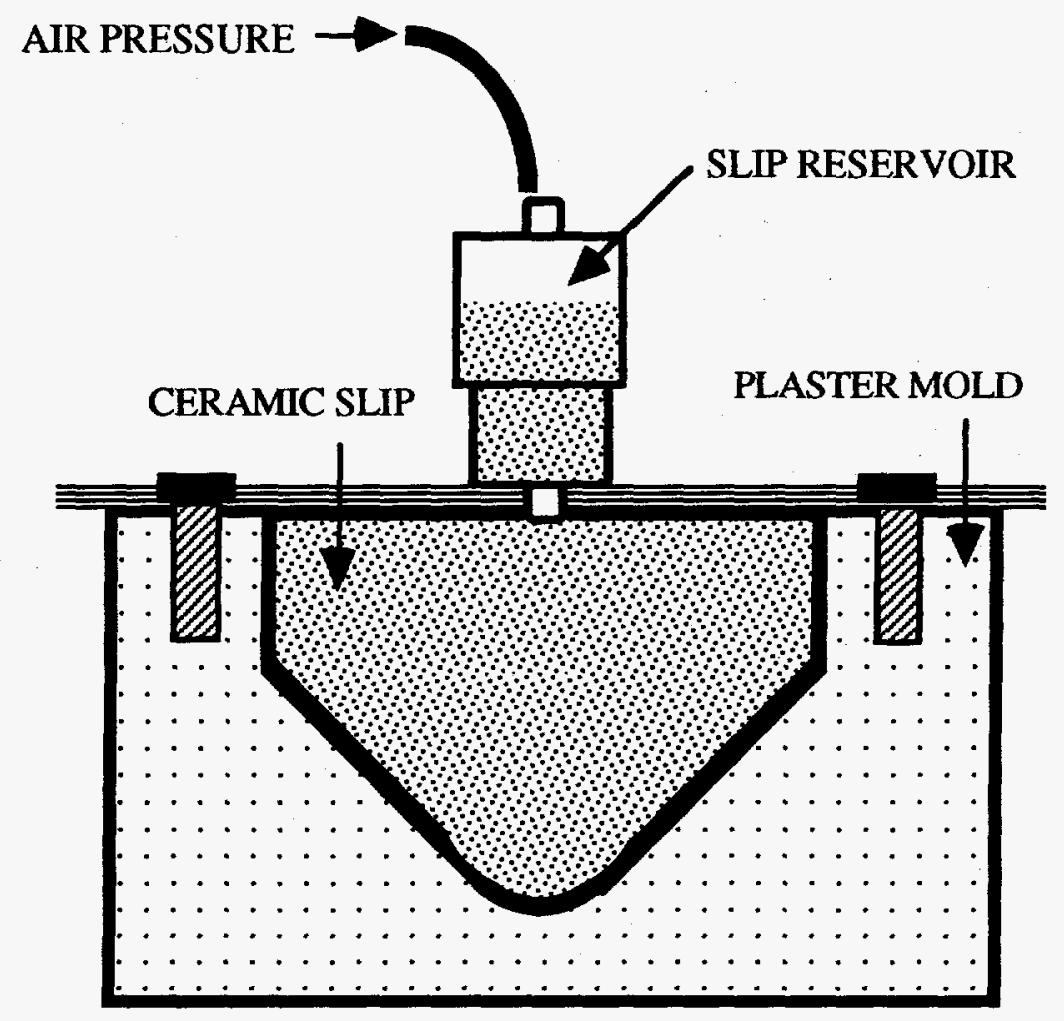

Figure 43. Schematic of set-up for Pressure Slip Casting (PSC) process.

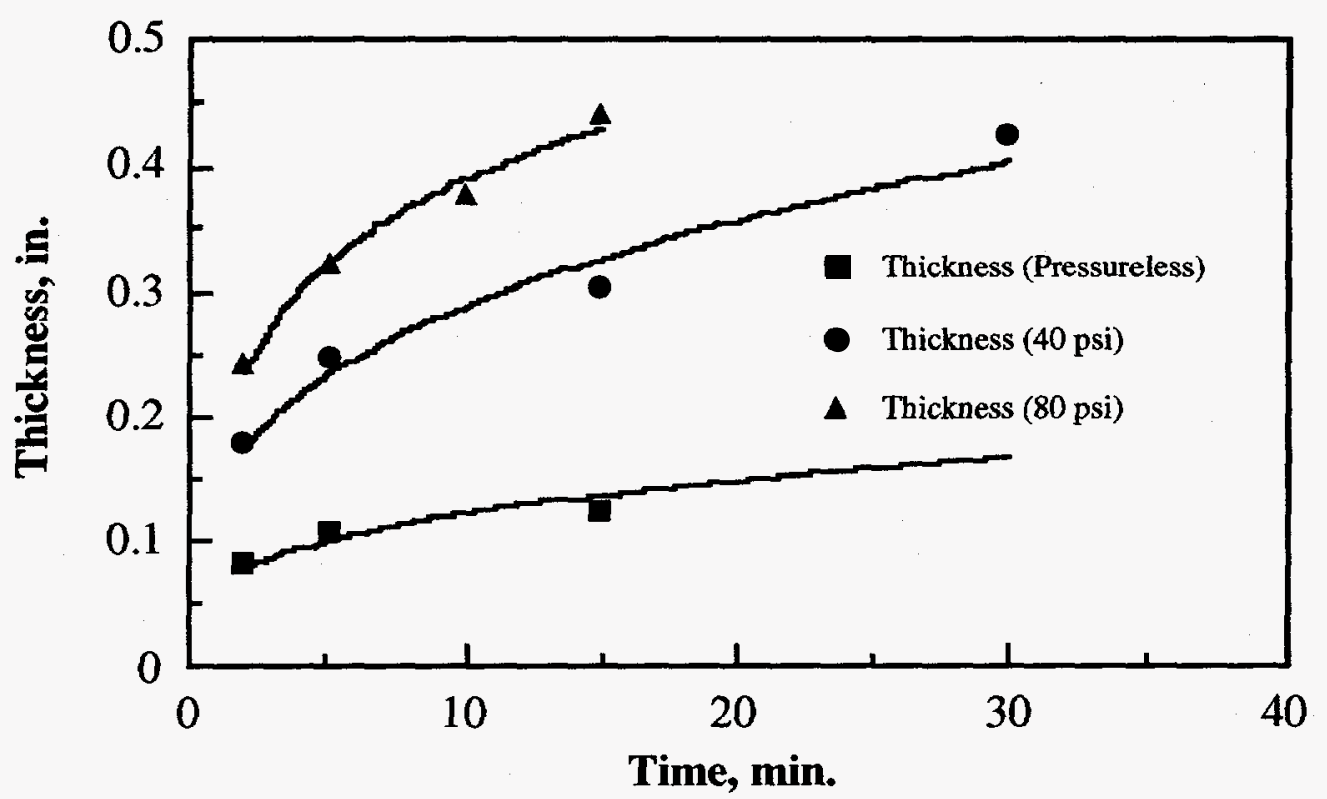

Figure 44. Effect of applied pressure on the wall thickness of cast body. 


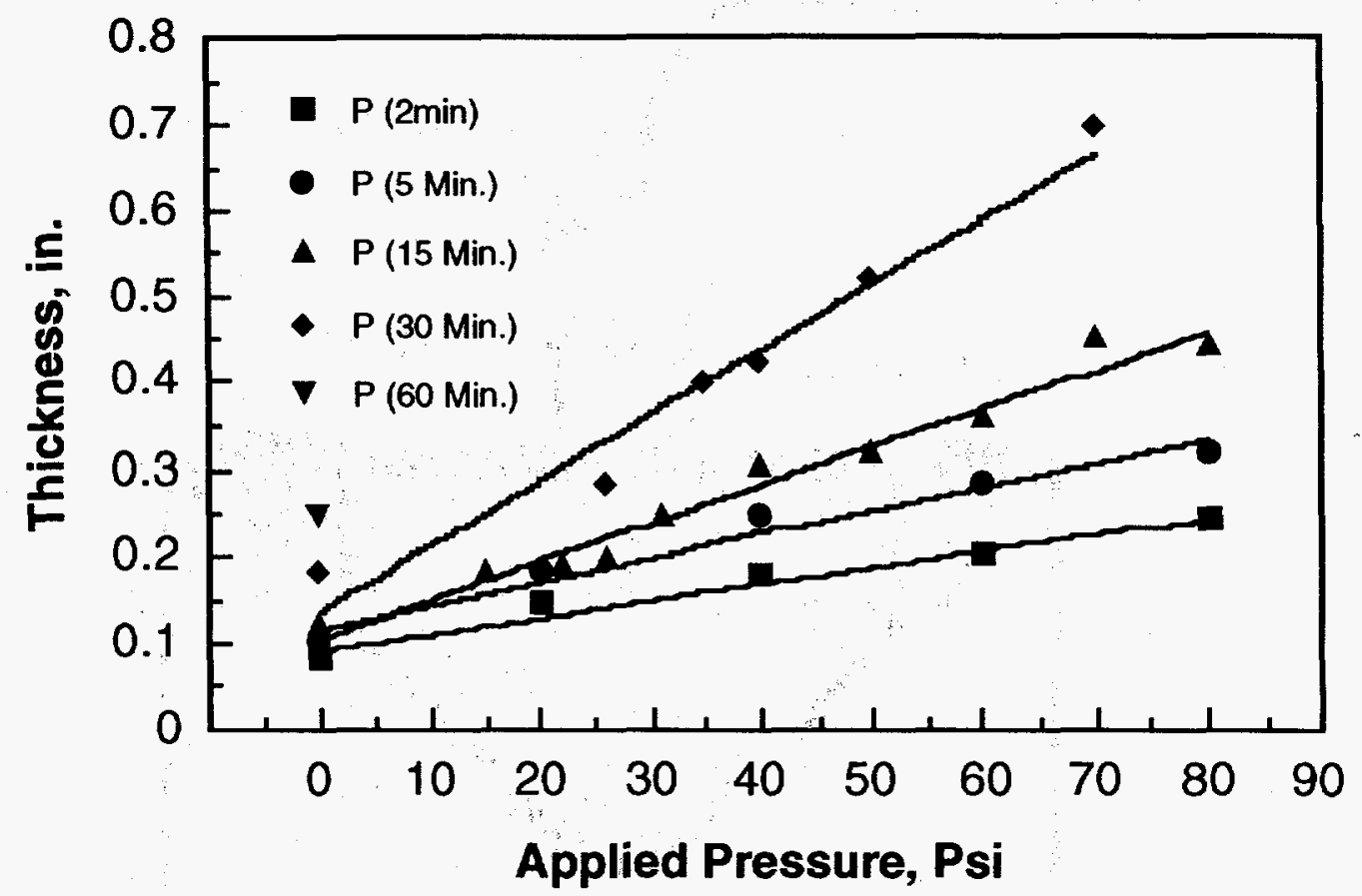

Figure 45. Effect of slip casting time on wall thickness of the cast body.

\section{Gel Casting}

This high potential near-net shape forming technique is being adapted to the fabrication of NZP ceramic based diesel engine port-liners and other components. Processing steps involved in the gel casting of NZP ceramics have been summarized in the flow chart of Fig. 46. Despite its advantages with respect to speed of forming and high green strength of the cast and dried part, several areas of this technique still need further examination; for instance, viscosity of the gel at the time of casting (which depends on the amount of solids loading), idle time between casting and gelation, flowing due to self weight of the semi-dry part after removal from the molds, and burn-out of the polymer. All of these areas will be adequately addressed during Phase II work. 


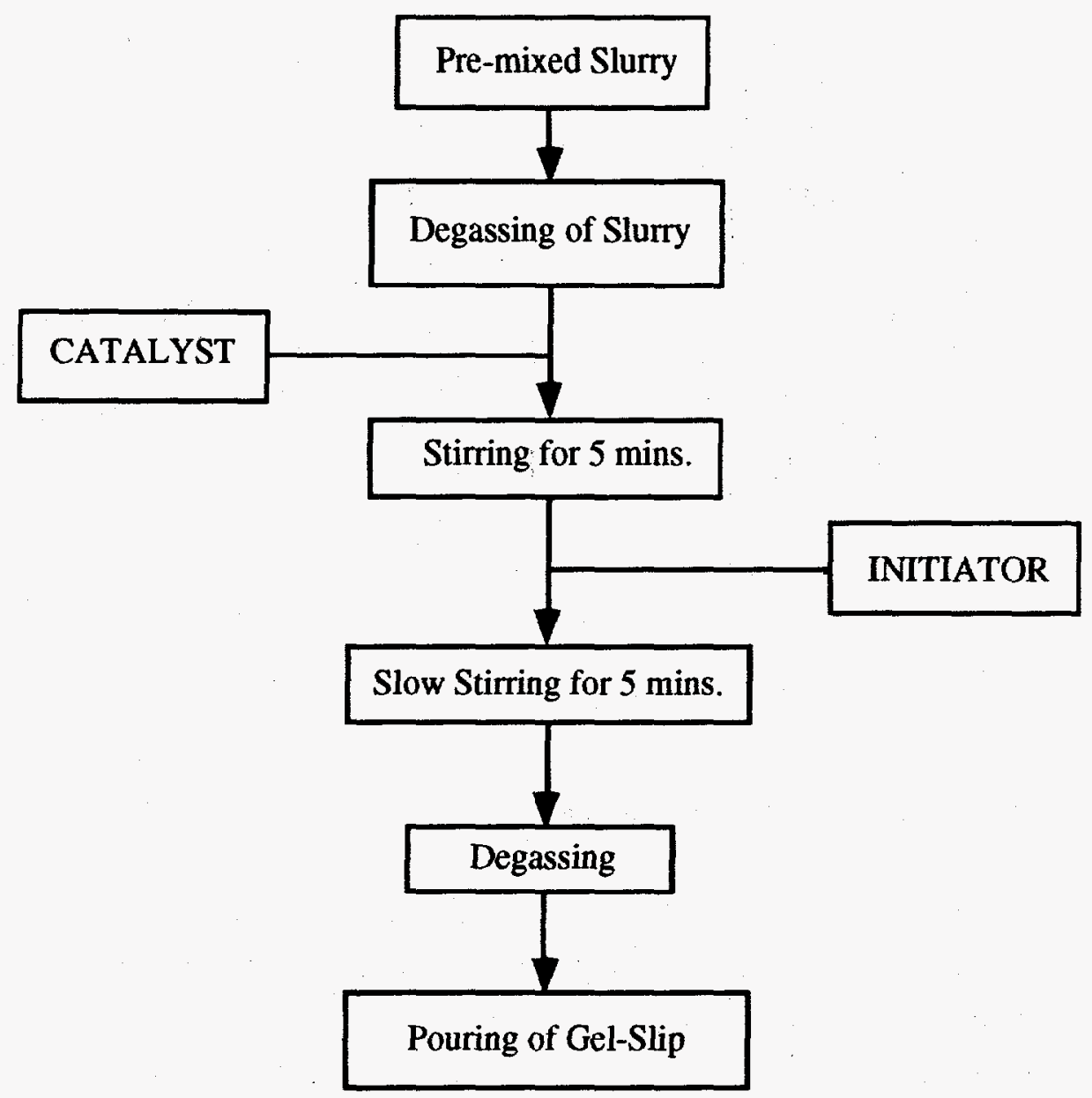

Figure 46. Schematic layout of the sequence involved in gel-casting procedure.

\section{Ultrasonic NDE Technique}

A "dry coupling", direct contact, transmission mode ultrasonic technique was tested and adapted for quality checks on finished NZP ceramic parts. As can be seen from Fig. 47 , the technique employs dry coupling transmitting and receiving transducers $\$$ between which the test material (NZP ceramic) is inserted. The transducers used were W-series transducers capable of operating in the frequency range $<50 \mathrm{kHz}$ to $>25 \mathrm{MHz}$ and designed for velocity measurements and high resolution testing. A PR35 ultrasonic pulser/receiverI acted as the source and transmitter of electric pulses which were recorded and analyzed using a Cathode Ray Oscilloscope (CRO).

\& Ultran Laboratories, Inc., Boalsburg, PA 16827-0719.

I JSR Ultrasonic Measurement Systems, Pittsford, NY 14534 


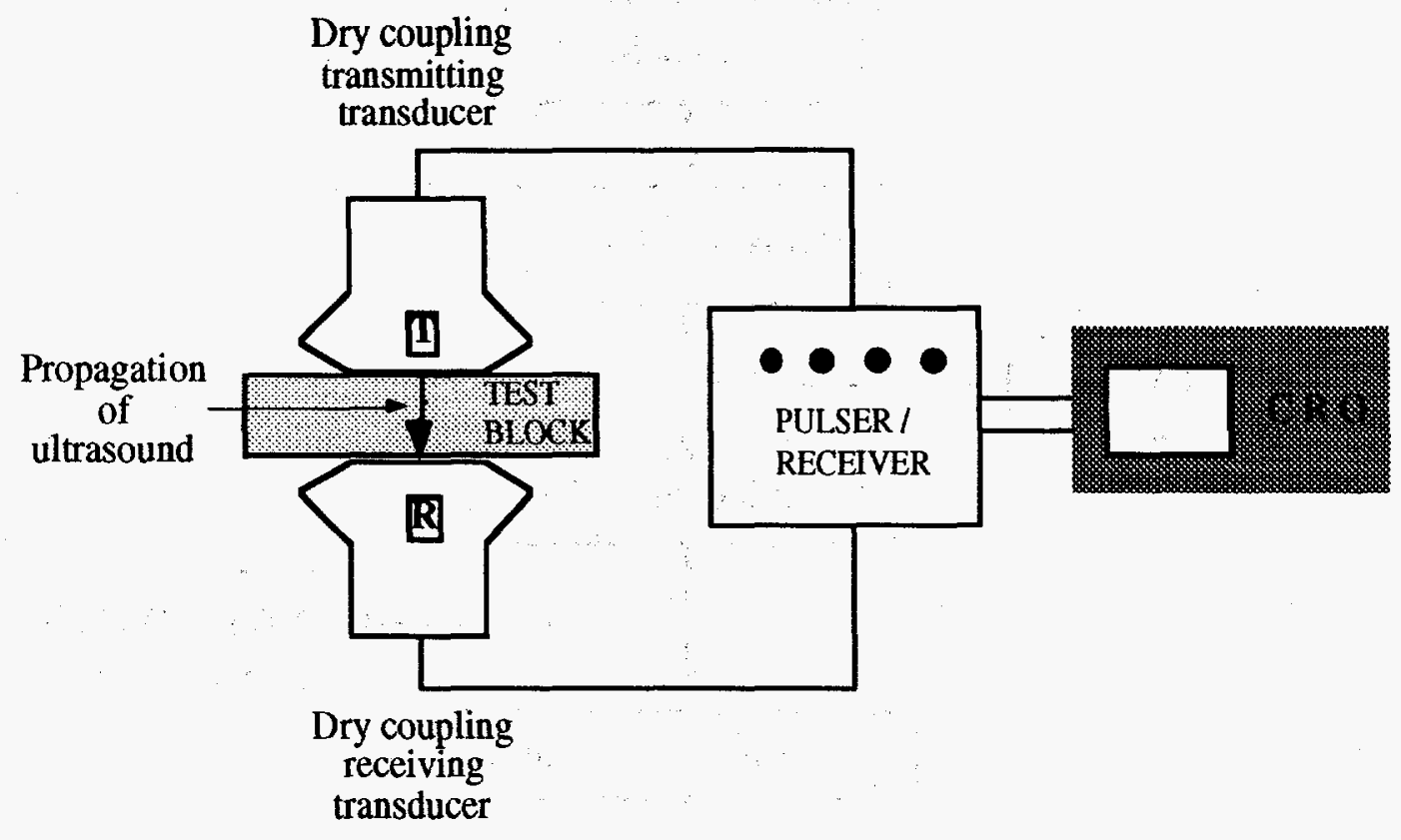

Figure 47. Schematic diagram of the ultrasonic NDE set-up used for flaw detection.

Parameters monitored were the time of flight, longitudinal wave velocity, and amplitude and number of pulses. This information was then processed for comparison with that of a standard. Deviations of the observed/measured parameters of the test sample from the standard were interpreted to be due to defects. In order to ascertain the technique's reliability, some of the seemingly defective samples were dissected to examine for defects. It was found that this technique gave a fairly accurate indication of the presence of flaws.

\section{New NZP materials}

As stated in the proposal, three more NZP systems where chosen for this study.

$$
\begin{aligned}
& \mathrm{Ca}_{1+\mathrm{x}} \mathrm{Zr}_{4} \mathrm{P}_{6-2 \mathrm{x}} \mathrm{Si}_{2 \mathrm{x}} \mathrm{O}_{24}(\mathrm{CSX}) \quad(\mathrm{x}=0.1,0.25,0.37) \\
& \mathrm{Sr}_{1+\mathrm{x}} \mathrm{Zr}_{4} \mathrm{P}_{6-2 \mathrm{x}} \mathrm{Si}_{2 \mathrm{x}} \mathrm{O}_{24} \text { (S'SX) ( } \quad(\mathrm{x}=0.1,0.25,0.37) \\
& \mathrm{Ca}_{(1+\mathrm{x}) / 2} \mathrm{Sr}_{(1+\mathrm{x}) / 2} \mathrm{Zr}_{4} \mathrm{P}_{6-2 \mathrm{x}} \mathrm{Si}_{2 \mathrm{x}} \mathrm{O}_{24}(\mathrm{CS} \mathrm{SX}) \quad(\mathrm{x}=0.1,0.25,0.37)
\end{aligned}
$$

Three compositions were synthesized by oxide mixing technique described earlier. Stoichiometric amounts of the precursors (after taking into account the LOI) for a specific composition were mixed, ball milled in alcohol for $20 \mathrm{hrs}$., dried in air and calcined for 6 hrs. at $1200^{\circ} \mathrm{C}$. Calcined powders were then subjected to XRD analysis. 
The XRD data indicated that the calcined material contained only the NZP phase in most compositions and, in a few, minor amounts of $\mathrm{ZrP}_{2} \mathrm{O}_{7}$ which typically disappeared after sintering. The corresponding XRD patterns are shown in Figures 48(a) to (c). Detailed characterization will be conducted during the Phase II effort.

\section{Microcracking Investigation by Acoustic Emission}

Using carefully selected wave guides, acoustic signal activity ("counts") emitted by test specimens were recorded. Initial tests consisted of recording acoustic emissions during heat-up of a specimen to and cool-down from $1000^{\circ} \mathrm{C}$. A Locan 320 system which was capable of detecting signals in the range of $3 \mathrm{kHz}$ to $1.2 \mathrm{MHz}$ with amplitudes up to $80 \mathrm{dBel}$ was used for detection of acoustic activities. The number of counts recorded was attempted to be correlated to the extent of microcracking in the specimen. It was observed that while no significant acoustic emission could be registered during heating, the opposite was true during cooling (specially below $350^{\circ} \mathrm{C}$ ); which is in agreement with previous experimental observations. These experiments also indicated that the number of acoustic emission counts is a function of the maximum temperature to which the samples are heated. More work on acoustic emission based detection of microcracking has been planned for the Phase II program of this project.

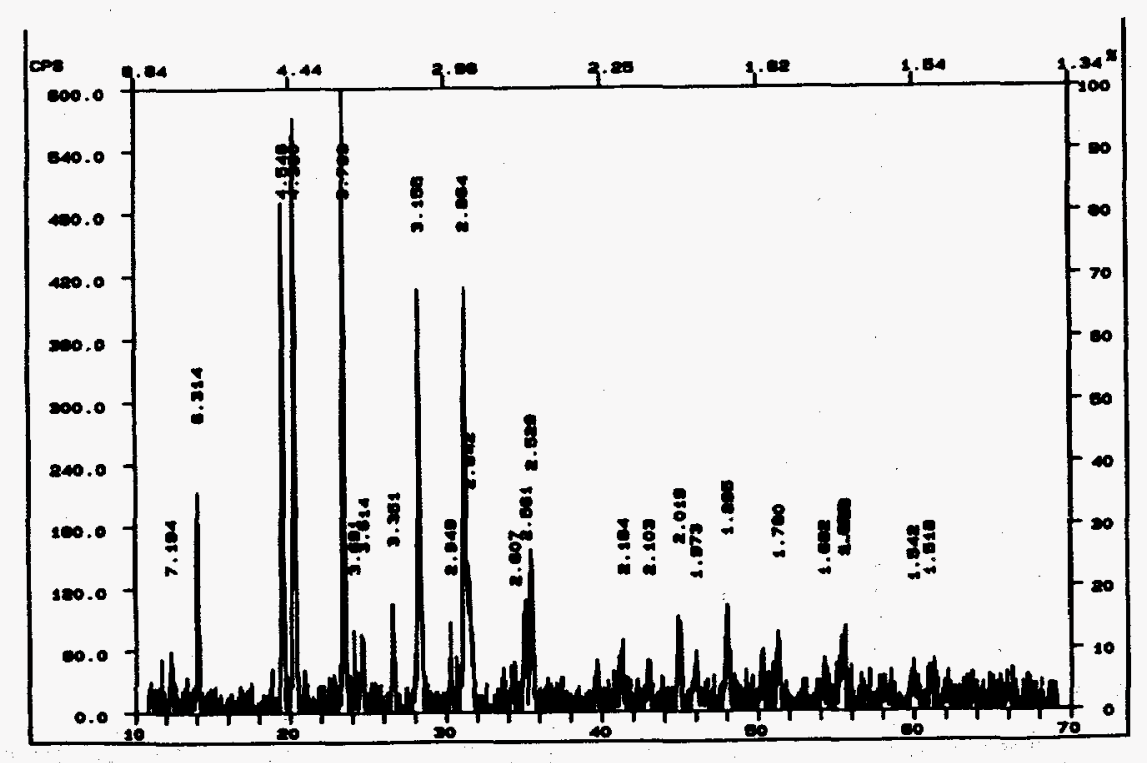

Figure 48 (a). XRD phase content data of C'SX material for $x=0.25$. 


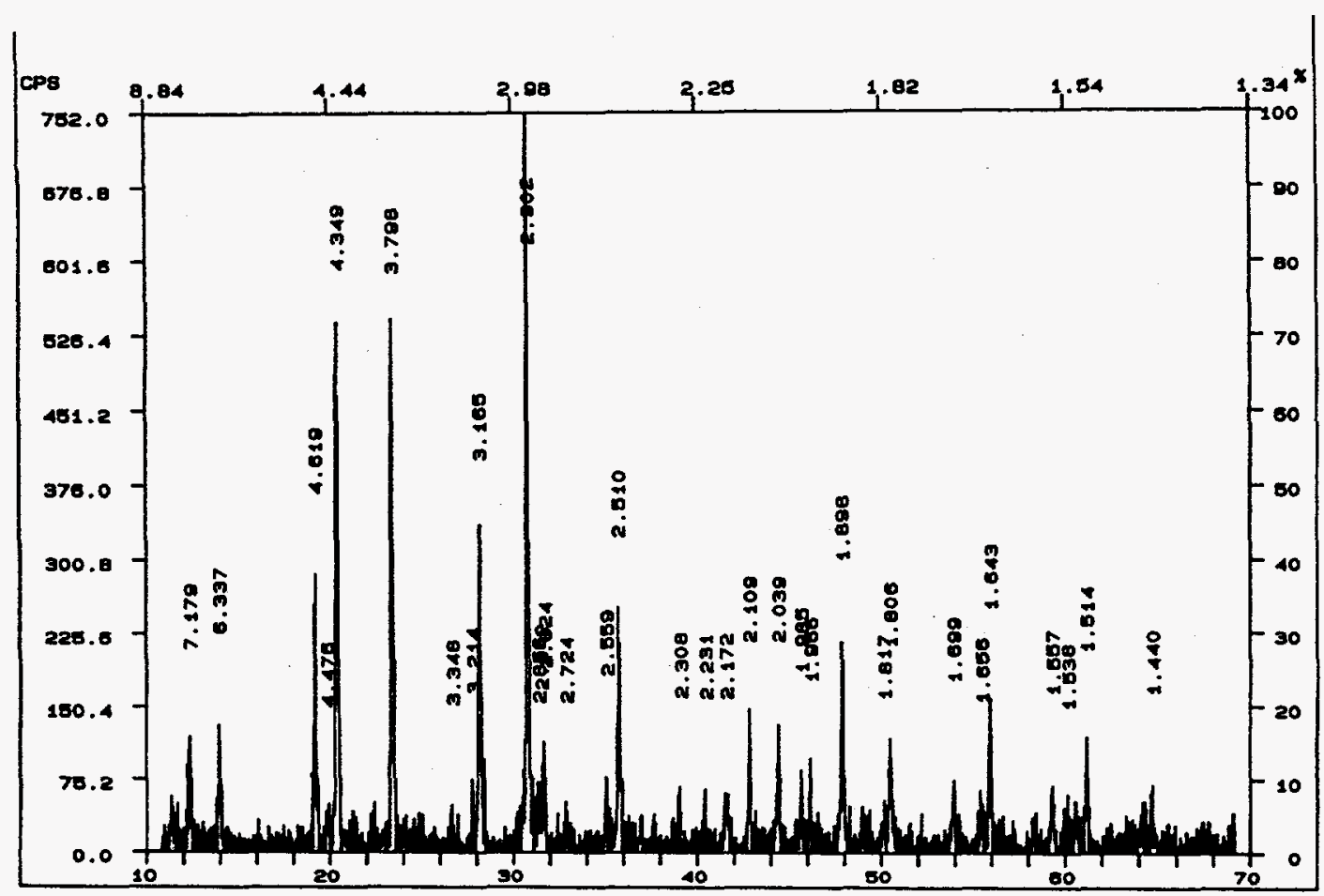

Figure 48(b). XRD phase content data of S'SX material for $x=0.25$.

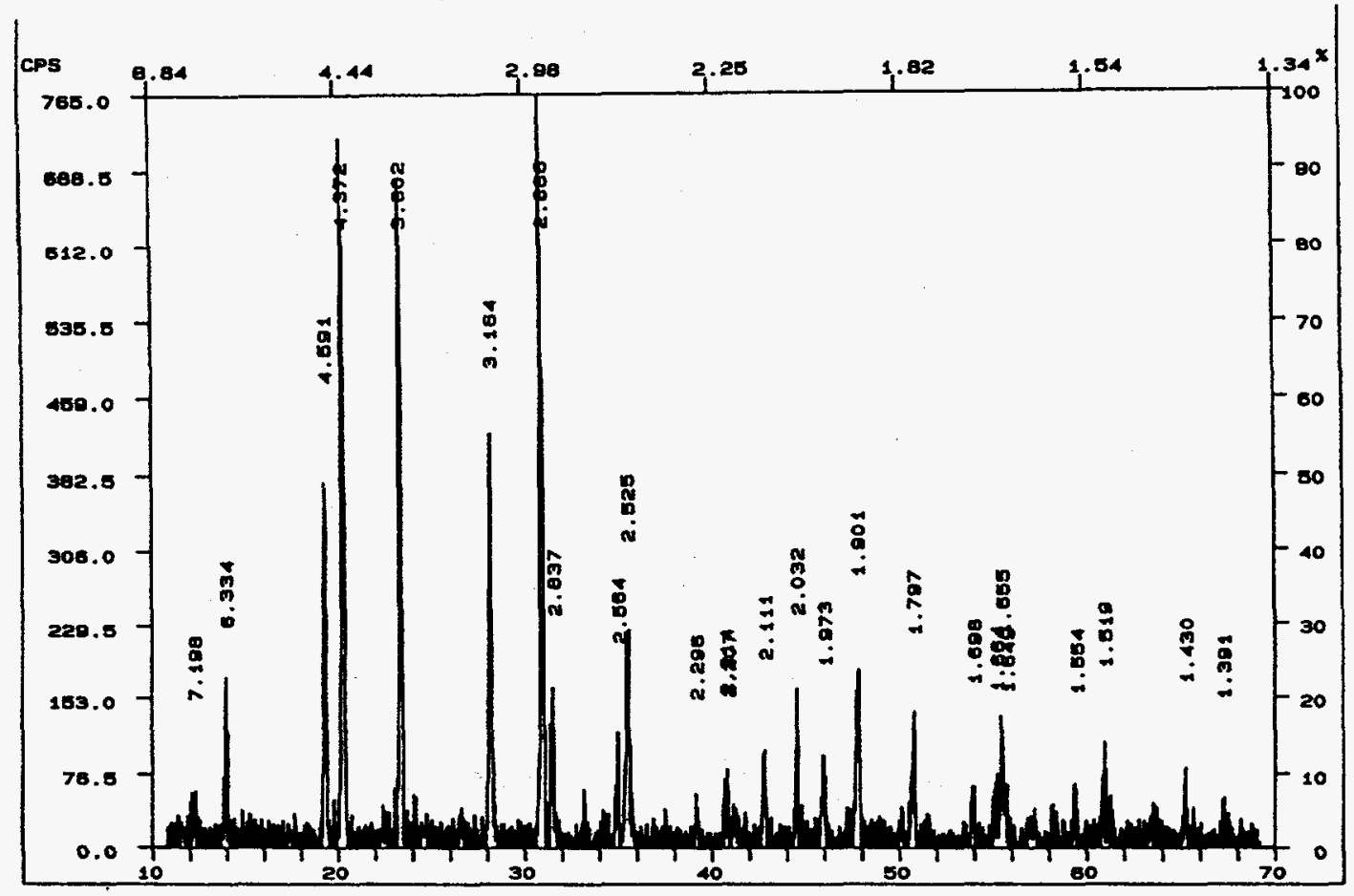

Figure 48(c). XRD phase content data of C'S'X material for $\mathrm{x}=0.25$. 


\section{CONCLUSIONS}

Work on this Phase I program has led to substantial progress towards the development of NZP ceramic based "cast-in-place" diesel engine port liners. Specific accomplishments and deductions have been summarized in the following:

1. Preliminary work on material property requirements using both finite element analysis (FEA) and metal casting trials converged on the following results: (i) large thermal gradients (and any associated stresses) in the NZP ceramic just at the start of metal casting and (ii) large compressive hoop (shrinkage) stresses that led to cracking of the NZP ceramic after the metal casting process.

2. Optimization of some of the process parameters involved in powder processing and slip casting of NZP ceramics was attempted. Specifically, studies of the effect of milling and calcination conditions; and moisture content of the mold on the final properties of the slip-cast and sintered body were completed.

3. Samples of BSX (Ba $\left.1+x \mathrm{Zr}_{4} \mathrm{P}_{6-2 x} \mathrm{Si}_{2 \mathrm{x}} \mathrm{O}_{24}\right)$ and $\mathrm{CSX}\left(\mathrm{Ca}_{1-\mathrm{x}} \mathrm{Sr}_{\mathrm{x}} \mathrm{Zr}_{4} \mathrm{P}_{6} \mathrm{O}_{24}\right)$ compositions for $x=0,0.17,0.25,0.375,0.5$ and $x=0,0.25,0.5$, respectively, were fabricated and subjected to detailed characterization. Characterization included evaluation of mechanical properties (flexure strength and elastic modulus), thermal properties (thermal diffusivity, thermal conductivity, thermal expansion, thermal stability and thermal shock) and microstructures.

4. Of the various BSX and CSX compositions, the BS-25 ( $x=0.25)$ and CS-50 $(x=0.50)$ materials had the highest strengths. In addition, the BS-25 and CS-50 materials exhibited the least thermal expansion hysteresis during thermal expansion testing for up to 250 cycles to $1250^{\circ} \mathrm{C}$. This result suggested that BS-25 and CS-50 were the most isotropic of all compositions tested.

5. The marked thermal expansion anisotropy of most of the other BSX and CSX materials was shown to be due to moisture-assisted microcracking during cooling (close to room temperature) through a carefully designed experiment. Direct evidence of the microcracking phenomenon was obtained through microstructural examinations. 
6. Microcracking was not only responsible for the observed differences in thermal expansion during thermal cycling (hysteresis) of a given sample but also for the low strengths of the anisotropic compositions.

7. Metal casting trials with a compliant layer introduced in between the metal and ceramic tubes was successful in preventing cracking of either the ceramic or metal due to shrinkage stresses. The resulting composite tube was structurally sound as was evident from X-ray computer tomography studies. Requisite optimum properties of the compliant layer and the ceramic are being obtained through iterative refinement of the finite element model based on the results of metal casting trials.

8. Alternative forming processes such as pressure slip casting and gel casting are under assessment. This Phase I experience has shown that both processes hold significant promise for speedy manufacturing of near-net shape NZP ceramic parts without compromise of quality.

9. In the search for new NZP type materials three more systems were selected for investigation. Preliminary testing of thermal expansion behavior and flexure strengths to isolate ultra-low thermal expansion, isotropic and high strength compositions is being conducted. (Detailed characterization of these materials will be undertaken and a complete database will be created.)

10. NDE techniques based on acoustic emission, for the detection and analysis of microcracking behavior in NZP materials, and ultrasonic transmission, for the detection of flaws in finished parts have been developed. The latter technique is already in use for quality control purposes. 


\section{REFERENCES}

1. J. J. Cleveland and R. C. Bradt, "Grain Size/Microcracking Relations for Psuedobrookite Oxides," J. Am. Ceram. Soc., 61[11-12], 478-81 (1978).

2. C. E. Holcombe, "Cyclic Plastic Deformation as a Possible Cause of Thermal Expansion Hysteresis of Fine-Grained Ceramic Materials," High Temp. Sci., 12, 63$66(1980)$.

3. G. Harshe, D. Agrawal and S. Limaye, "High Temperature Mechanical Properties and Chemical Stability of $\mathrm{Ba}_{1+\mathrm{x}} \mathrm{Zr}_{4} \mathrm{P}_{6-2 \mathrm{x}} \mathrm{Si}_{2 \mathrm{x}} \mathrm{O}_{24}$ Low-Thermal-Expansion Ceramics," J. Am. Ceram. Soc., 77[7], 1965-68 (1994).

4. C. Y. Huang et al., "Synthesis, Thermal Expansion, and Microcracking in $\mathrm{Ba}_{1+\mathrm{x}} \mathrm{Zr}_{4} \mathrm{P}_{6-2 \mathrm{x}} \mathrm{Si}_{2 \mathrm{x}} \mathrm{O}_{24}$ and $\mathrm{Sr}_{1-\mathrm{x}} \mathrm{Zr}_{4} \mathrm{P}_{6-2 \mathrm{~S}} \mathrm{Si}_{2 \mathrm{x}} \mathrm{O}_{24}$ Systems"; Presented at the 92nd Annual Meeting of the American Ceramic Society, Cincinnati, OH, April 29, 1991 (Basic Science Division, Paper No. 87-B-91).

5. S. Y. Limaye et al., "Synthesis, Sintering, and Thermal Expansion of $\mathrm{Ca}_{1-\mathrm{x}} \mathrm{Sr}_{\mathbf{x}}$ $\mathrm{Zr}_{4} \mathrm{P}_{6} \mathrm{O}_{24}$ - An Ultra Low Thermal Expansion Ceramic System," J. Mater. Sci., 26, 93-98 (1991).

6. MIL-STD-1941 (MR), " Flexure Strength of High Performance Ceramics at Ambient Temperature ", November 1983. 


\section{ACKNOWLEDGMENTS}

LoTEC, Inc. gratefully acknowledges the funding provided the U.S. Department of Energy, Assistant Secretary for Energy Efficiency and Renewable Energy, Office of Transportation Technologies, as part of the Ceramic Technology Project of the Propulsion System Materials Program, under contract DE-AC05-96OR22464 with Lockheed Martin Energy Research Corporation.

Authors would like to thank T. Barrett Jackson for his work as an Industrial Fellow as the High Temperature Materials Laboratory of Oak Ridge National Laboratory. Authors would also like to acknowledge the help and guidance provided by various personnel (especially Dr. V. J. Tennery, Wally Porter, Ralph Dinwiddie) at HTML. The technical help and critique provided by David Stinton, S. Subramaniam was vital to the completion of Phase I research. The efforts by Michael Lehto of RAE Corp. in Salt Lake City, in completing the preliminary finite element analysis are gratefully acknowledged. 


\section{INTERNAL DISTRIBUTION}

Central Research Library (2) Document Reference Section

Laboratory Records Department (2)

Laboratory Records, ORNL RC

ORNL Patent Section

M\&C Records Office (3)

L. F. Allard, Jr.

L. D. Armstrong

P. F. Becher

R. F. Bernal

T. M. Besmann

P. J. Blau

R. A. Bradley

K. Breder

C. R. Brinkman

V. R. Bullington

G. M. Caton

S. J. Chang

A. Choudhury

D. D. Conger

R. H. Cooper, Jr.

S. A. David

J. L. Ding

M. K. Ferber

R. L. Graves

D. L. Greene

H. W. Hayden, Jr.

E. E. Hoffman

C. R. Hubbard
M. A. Janney

D. R. Johnson (5)

D. Joslin

R. R. Judkins

M. A. Karnitz

B. L. Keyes

H. D. Kimrey, Jr.

W. Y. Lee

K. C. Liu

E. L. Long, Jr.

W. D. Manly

R. W. McClung

D. J. McGuire

T. A. Nolan

A. E. Pasto

K. P. Plucknett

M. H. Rawlins

M. L. Santella

A. C. Schaffhauser

E. J. Soderstrom

D. P. Stinton

R. W. Swindeman

T. N. Tiegs

B. H. West

S. G. Winslow

J. M. Wyrick 


\section{EXTERNAL DISTRIBUTION}

Pioneering Research Info. Ctr.

E.I. Dupont de Nemours \& Co.

Experimental Station

P.O. Box 80302

Wilmington DE 19880-0302

Jeffrey Abboud

U.S. Advanced Ceramics Assoc.

1600 Wilson Blvd., Suite 1008

Arlington VA 22209

James H. Adair

University of Florida

Materials Science \& Engineering

317 MAE Bldg.

Gainesville FL 32611-2066

Donald F. Adams

University of Wyoming

Mechanical Engineering Dept.

P.O. Box 3295

Laramie WY 82071

Andrzej Aeamski

Materials Conversion Group

236-B Egidi Drive

Wheeling IL 60090

Jalees Ahmad

AdTech Systems Research Inc.

Solid Mechanics

1342 N. Fairfield Road

Dayton OH 45432-2698

Yoshio Akimune

NISSAN Motor Co., Ltd.

Materials Research Laboratory

1 Natsushima-Cho

Yokosuka 237

JAPAN

Mufit Akinc

Iowa State University

322 Spedding Hall

Ames IA 50011
Ilhan A. Aksay

Princeton University

A313 Engineering Quadrangle

Princeton NJ 08544-5263

Charles Aldridge

Heany Industries, Inc.

249 Briarwood Lane

Scottsville NY 14546

Joseph E. Amaral

Instron Corporation

Corporate Engineering Office

100 Royale Street

Canton MA 02021

Edward M. Anderson

Aluminum Company of America

N. American Industrial Chemical

P.O. Box 300

Bauxite AR 72011

Norman C. Anderson

Ceradyne, Inc.

Ceramic-to-Metal Division

3169 Redhill Avenue

Costa Mesa CA 92626

Don Anson

$\mathrm{BCL}$

Thermal Power Systems

505 King Avenue

Columbus OH 43201-2693

Thomas Arbanas

G.B.C. Materials Corporation

580 Monastery Drive

Latrobe PA 15650-2698

Frank Armatis

3M Company

Building $60-1 \mathrm{~N}-01$

St. Paul MN 55144-1000 
Everett B. Arnold

Detroit Diesel Corporation

Mechanical Systems Technology

13400 Outer Drive West

Detroit MI 48239-4001

Bertil Aronsson

Sandvik AB

S-12680

Stockholm Lerkrogsvagen 19

SWEDEN

Dennis Assanis

University of Michigan

Dept. of Mechanical Engineering

321 W.E. Lay, N.C.

Ann Arbor MI 48109

V. S. Avva

North Carolina A\&T State Univ. Dept. of Mechanical Engineering

Greensboro NC 27411

Patrick Badgley

Sky Technologies, Inc.

2815 Franklin Drive

Columbus IN 47201

Sunggi Baik

Pohang Institute Sci.\& Tech.

P.O. Box 125

Pohang 790-600

KOREA

John M. Bailey

Consultant

Caterpillar, Inc.

P.O. Box 1875

Peoria IL 61656-1875

Bob Baker

Ceradyne, Inc.

3169 Redhill Avenue

Costa Mesa CA 92626

Frank Baker

Aluminum Company of America

Alcoa Technical Center

Alcoa Center PA 15069
Clifford P. Ballard

AlliedSignal Aerospace Company

Ceramics Program

P.O. Box 1021

Morristown NJ 07962-1021

B. P. Bandyopadhyay

ELID Team

Wako Campus

2-1 Hirosawa Wako-shi

Saitama 351-01

JAPAN

P. M. Barnard

Ruston Gas Turbines Limited

P.O. Box 1

Lincoln LN2 5DJ

ENGLAND

Harold N. Barr

Hittman Corporation

9190 Red Branch Road

Columbia MD 21045

Renald D. Bartoe

Vesuvius McDanel

510 Ninth Avenue

Box 560

Beaver Falls PA 15010-0560

David L. Baty

Babcock \& Wilcox - LRC

P.O. Box 11165

Lynchburg VA 24506-1165

Donald F. Baxter, Jr.

ASM International

Advanced Materials \& Processes

Materials Park $\mathrm{OH}$ 44073-0002

M. Brad Beardsley

Caterpillar Inc.

Technical Center Bldg. E

P.O. Box 1875

Peoria IL 61656-1875 
John C. Bell

Shell Research Limited

Thornton Research Centre

P.O. Box 1

Chester $\mathrm{CH} 13 \mathrm{SH}$

ENGLAND

Larry D. Bentsen

BFGoodrich Company

R\&D Center

9921 Brecksville Road

Brecksville OH 44141

Tom Bernecki

Northwestern University

1801 Maple Avenue

Evanston IL 60201-3135

Charles F. Bersch

Institute for Defense Analyses

1801 N. Beauregard Street

Alexandria VA 22311

Ram Bhatt

NASA Lewis Research Center

21000 Brookpark Road

Cleveland $\mathrm{OH} 44135$

Deane I. Biehler

Caterpillar Inc.

Engineering Research Materials

P.O. Box 1875, Bldg. E

Peoria IL 61656-1875

William D. Bjorndahl

TRW, Inc.

One Space Park, MS:R6-2188

Building 01, Room 2040

Redondo Beach CA 90278

Keith A. Blakely

Advanced Refractory Technologies, Inc.

699 Hertel Avenue

Buffalo NY. 14207

Edward G. Blanchard

Netzsch Inc.

119 Pickering Way

Exton PA 19341
Bruce Boardman

Deere \& Company Technical Ctr. 3300 River Drive

Moline IL 61265

Lawrence P. Boesch

EER Systems Corp.

1593 Spring Hill Road

Vienna VA 22182-2239

Donald H. Boone

Boone \& Associates

2412 Cascade Drive

Walnut Creek CA 94598-4313

Tom Booth

AlliedSignal, Inc.

AiResearch Los Angeles Division

2525 West 190th Street

Torrance CA 90509-2960

Raj Bordia

University of Washington

Roberts Hall

Box 35212

Seattle WA $98195-2120$

Tibor Bornemisza

Energy Technologies Applications, Inc.

5064 Caminito Vista Lujo

San Diego CA 92130-2846

J.A.M. Boulet

University of Tennessee

Engineering Science \& Mechanics

Knoxville TN 37996-2030

Leslie J. Bowen

Materials Systems

53 Hillcrest Road

Concord MA 01742

Steven C. Boyce

Air Force Office of Scientific

Research

AFOSR/NA Bldg. 410

Bolling AFB DC 20332-6448 
Steve Bradley

UOP Research Center

50 E. Algonquin Road

Des Plaines IL 60017-6187

Michael C. Brands

Cummins Engine Company, Inc.

P.O. Box 3005, Mail Code 50179

Columbus IN 47201

Raymond J. Bratton

Westinghouse Science \& Technology

1310 Beulah Road

Pittsburgh PA 15235

John J. Brennan

United Technologies Corporation

Silver Lane, MS:24

East Hartford CT 06108

Terrence K. Brog

Golden Technologies Company

4545 McIntyre Street

Golden CO 80403

Gunnar Broman

317 Fairlane Drive

Spartanburg SC 29302

Alan Brown

P.O. Box 882

Dayton NJ 08810

Jesse J. Brown

VPI \& SU

Ctr. for Adv. Ceram. Mater.

Blacksburg VA 24061-0256

Sherman D. Brown

University of Illinois

Materials Science \& Engineering

105 South Goodwin Avenue

Urbana IL 61801

S. L. Bruner

Ceramatec, Inc.

2425 South 900 West

Salt Lake City UT 84119
Walter Bryzik

U.S. Army Tank Automotive

Command

R\&D Center, Propulsion Systems

Warren MI 48397-5000

Curt V. Burkland

AMERCOM, Inc.

8928 Fullbright Avenue

Chatsworth CA 91311

Bill Bustamante

AMERCOM, Inc.

8928 Fullbright Avenue

Chatsworth CA 91311

Oral Buyukozturk

Massachusetts Institute of

Technology

77 Massachusetts Ave., Rm 1-280

Cambridge MA 02139

David A. Caillet

Ethyl Corporation

451 Florida Street

Baton Rouge La 70801

Roger Cannon

Rutgers University

P.O. Box 909

Piscataway NJ 08855-0909

Scott Cannon

P.O. Box 567254

Atlanta GA 30356

Harry W. Carpenter

1844 Fuerte Street

Fallbrook CA 92028

David Carruthers

Kyocera Industrial Ceramics

P.O. Box 2279

Vancouver WA 98668-2279

Calvin H. Carter, Jr.

Cree Research, Inc.

2810 Meridian Parkway

Durham NC 27713 
J. David Casey

35 Atlantis Street

West Roxbury MA 02132

Jere G. Castor

J. C. Enterprise

5078 N. 83rd Street

Scottsdale AZ 85250

James D. Cawley

Case Western Reserve University

Materials Science \& Engineering

Cleveland OH 44106

Thomas C. Chadwick

Den-Mat Corporation

P.O. Box 1729

Santa Maria CA 93456

Ronald H. Chand

Chand Kare Technical Ceramics

2 Coppage Drive

Worcester MA 01603-1252

William Chapman

Williams International Corp.

2280 W. Maple Road

Walled Lake MI 48390-0200

Ching-Fong Chen

LECO Corporation

3000 Lakeview Avenue

St. Joseph MI 49085

William J. Chmura

Torrington Company

59 Field Street

Torrington CT 06790-4942

Tsu-Wei Chou

University of Delaware

201 Spencer Laboratory

Newark DE 19716

R. J. Christopher

Ricardo Consulting Engineers

Bridge Works

Shoreham-By-Sea W. Sussex

BN435FG ENGLAND
Joel P. Clark

Massachusetts Institute of

Technology

Room 8-409

Cambridge MA 02139

Giorgio Clarotti

Commission of the European Comm

DGXII-C3, MO75, 1-53;

200 Rue de la Loi

B-1049 Brussels

BELGIUM

W. J. Clegg

ICI Advanced Materials

P.O. Box 11, The Heath

Runcorn Cheshire WA7 4QE

ENGLAND

William S. Coblenz

Adv. Research Projects Agency

3701 N. Fairfax Drive

Arlington VA 22203

Gloria M. Collins

ASTM

1916 Race Street

Philadelphia PA 19103

William C. Connors

Sundstrand Aviation Operations

Materials Science \& Engineering

4747 Harrison Avenue

Rockford IL 61125-7002

John A. Coppola

Carborundum Company

Niagara Falls R\&D Center

P.O. Box 832

Niagara Falls NY 14302

Normand D. Corbin

Norton Company

SGNICC/NRDC

Goddard Road

Northboro MA 01532-1545 
Douglas Corey

AlliedSignal, Inc.

2525 West 190th Street, MS:T52

Torrance CA 90504-6099

Keith P. Costello

Chand/Kare Technical Ceramics

2 Coppage Drive

Worcester MA 01603-1252

Ed L. Courtright

Pacific Northwest Laboratory

MS:K3-59

Richland WA 99352

Anna Cox

Mitchell Market Reports

P.O. Box 23

Monmouth Gwent NP5 4YG

UNITED KINGDOM

J. Wesley Cox

BIRL

1801 Maple Avenue

Evanston IL 60201-3135

Art Cozens

Instron Corporation

3414 Snowden Avenue

Long Beach CA 90808

Mark Crawford

New Technology Week

4604 Monterey Drive

Annandale VA 22003

Richard A. Cree

Markets \& Products, Inc.

P.O. Box 14328

Columbus $\mathrm{OH}$ 43214-0328

Les Crittenden

Vesuvius McDanel

Box 560

Beaver Falls PA 15010

M. J. Cronin

Mechanical Technology, Inc.

968 Albany-Shaker Road

Latham NY 12110
Gary M. Crosbie

Ford Motor Company

20000 Rotunda Drive

MD-2313, SRL Building

Dearborn MI 48121-2053

Floyd W. Crouse, Jr.

U.S. Department of Energy

Morgantown Energy Tech. Ctr.

P.O. Box 880

Morgantown WV 26505

John Cuccio

AlliedSignal Engines

P.O. Box 52180, MS:1302-2Q

Phoenix AZ 85072-2180

Raymond A. Cutler

Ceramatec, Inc.

2425 South 900 West

Salt Lake City UT 84119

Stephen C. Danforth

Rutgers University

P.O. Box 909

Piscataway NJ 08855-0909

Sankar Das Gupta

Electrofuel Manufacturing Co.

9 Hanna Avenue

Toronto Ontario MGK-1W8

CANADA

Frank Davis

AlliedSignal Aerospace Company

7550 Lucerne Drive, \#203

Middleburg Heights OH 44130

Robert F. Davis

North Carolina State University

Materials Engineering Department

P.O. Box 7907

Raleigh NC 27695

George C. DeBell

Ford Motor Company

Scientific Research Lab

P.O. Box 2053, Room S2023

Dearborn MI 48121-2053 
Michael DeLuca

RSA Research Group

1534 Claas Ave.

Holbrook NY 11741

Gerald L. DePoorter

Colorado School of Mines

Metallurgical \& Materials Engr

Golden CO 80401

\section{J. F. DeRidder}

Omni Electro Motive, Inc.

12 Seely Hill Road

Newfield NY 14867

Nick C. Dellow

Materials Technology Publications

40 Sotheron Road

Watford Herts WD1 2QA

UNITED KINGDOM

L. R. Dharani

University of Missouri-Rolla

224 M.E.

Rolla MO 65401

Douglas A. Dickerson

Union Carbide Specialty Powders

1555 Main Street

Indianapolis IN 46224

John Dodsworth

Vesuvius Research \& Development

Technical Ceramics Group

Box 560

Beaver Falls PA 15010

B. Dogan

Institut fur Werkstofforschung

GKSS-Forschungszentrum Geesthacht

Max-Planck-Strasse

D-2054 Geesthacht

GERMANY

Alan Dragoo

U.S. Department of Energy

ER-131, MS:F-240

Washington DC 20817
Jean-Marie Drapier

FN Moteurs S.A.

Material and Processing

B-4041 Milmort (Herstal)

BELGIUM

Kenneth C. Dreitlein

United Technologies Res. Ctr.

Silver Lane

East Hartford CT 06108

Robin A.L. Drew

McGill University

3450 University Street

Montreal Quebec H3A 2A7

CANADA

Winston H. Duckworth

BCL

Columbus Division

505 King Avenue

Columbus OH 43201-2693

Ernest J. Duwell

3M Abrasive Systems Division

3M Center

St. Paul MN 55144-1000

Chuck J. Dziedzic

GTC Process Forming Systems

4545 McIntyre Street

Golden CO 80403

Robert J. Eagan

Sandia National Laboratories

Engineered Mater, \& Proc.

P.O. Box 5800

Albuquerque - NM 87185-5800

Harry E. Eaton

United Technologies Corporation

Silver Lane

East Hartford CT 06108

Harvill C. Eaton

Louisiana State University

240 Thomas Boyd Hall

Baton Rouge LA 70803 


\section{J. J. Eberhardt}

U.S. Department of Energy

Office of Transportation Mater.

CE-34, Forrestal Building

Washington DC 20585

Jim Edler

Eaton Corporation

26201 Northwestern Highway

P.O. Box 766

Southfield MI 48037

G. A. Eisman

Dow Chemical Company

Ceramics and Advanced Materials

52 Building

Midland MI 48667

William A. Ellingson

Argonne National Laboratory

Energy Technology Division

9700 S. Cass Avenue

Argonne IL 60439

Anita Kaye M. Ellis

Machined Ceramics

629 N. Graham Street

Bowling Green KY 42101

Glen B. Engle

Nuclear \& Aerospace Materials

16716 Martincoit Road

Poway CA 92064

Kenneth A. Epstein

Dow Chemical Company

2030 Building

Midland MI 48674

Art Erdemir

Argonne National Laboratory

9700 S. Cass Avenue

Argonne IL 60439

E. M. Erwin

Lubrizol Corporation

17710 Riverside Drive

Lakewood $\mathrm{OH} 44107$
John N. Eustis

U.S. Department of Energy

Industrial Energy Efficiency

CE-221, Forrestal Building

Washington DC 20585

W. L. Everitt

Kyocera International, Inc.

8611 Balboa Avenue

San Diego CA 92123

Gordon Q. Evison

332 S. Michigan Avenue

Suite 1730

Chicago IL 60604

John W. Fairbanks

U.S. Department of Energy

Office of Propulsion Systems

CE-322, Forrestal Building

Washington DC 20585

Tim Fawcett

Dow Chemical Company

Advanced Ceramics Laboratory

1776 Building

Midland MI 48674

Robert W. Fawley

Sundstrand Power Systems

Div. of Sundstrand Corporation

P.O. Box 85757

San Diego CA 92186-5757

Jeff T. Fenton

Vista Chemical Company

900 Threadneedle

Houston TX 77079

Larry Ferrell

Babcock \& Wilcox

Old Forest Road

Lynchburg VA 24505

Raymond R. Fessler

BIRL

1801 Maple Avenue

Evanston IL 60201 
Ross F. Firestone

Ross Firestone Company

188 Mary Street

Winnetka IL 60093-1520

Sharon L. Fletcher

Arthur D. Little, Inc.

15 Acorn Park

Cambridge MA 02140-2390

Michael Foley

Norton Company

Goddard Road

Northboro MA 01532-2527

Thomas F. Foltz

Textron Specialty Materials

2 Industrial Avenue

Lowell MA 01851

Renee G. Ford

Materials and Processing Report

P.O. Box 72

Harrison NY 10528

John Formica

Supermaterials

2020 Lakeside Avenue

Cleveland $\mathrm{OH} 44114$

Edwin Frame

Southwest Research Institute

P.O. Drawer 28510

San Antonio TX 78284

Armanet Francois

French Scientific Mission

4101 Reservoir Road, N.W.

Washington DC 20007-2176

R. G. Frank

Technology Assessment Group

10793 Bentley Pass Lane

Loveland $\mathrm{OH} 45140$

David J. Franus

Forecast International

22 Commerce Road

Newtown CT 06470
Marc R. Freedman

NASA Lewis Research Center

21000 Brookpark Road, MS:49-3

Cleveland $\mathrm{OH} 44135$

Douglas Freitag

Bayside Materials Technology

17 Rocky Glen Court

Brookeville MD 20833

Brian R.T. Frost

Argonne National Laboratory 9700 S. Cass Avenue, Bldg. 900

Argonne IL 60439

Lawrence R. Frost

Instron Corporation

100 Royall Street

Canton MA 02021

Xiren Fu

Shanghai Institute of Ceramics 1295 Ding-xi Road

Shanghai 200050

CHINA

J. P. Gallagher

University of Dayton Research

Institute

300 College Park, JPC-250

Dayton OH 45469-0120

Garry Garvey

Golden Technologies Company

4545 McIntyre Street

Golden CO 80403

Richard Gates

NIST

Materials Bldg., A-256

Gaithersburg MD 20899

L. J. Gauckler

ETH-Zurich

Sonneggstrasse 5

CH-8092 Zurich 8092

SWITZERLAND 
D. Gerster

CEA-DCOM

33 Rue De La Federation

Paris 75015

FRANCE

John Ghinazzi

Coors Technical Ceramics Co.

1100 Commerce Park Drive

Oak Ridge TN 37830

Robert Giddings

General Electric Company

P.O. Box 8

Schenectady NY 12301

A. M. Glaeser

University of California

Lawrence Berkeley Laboratory

Hearst Mining Building

Berkeley CA 94720

Joseph W. Glatz

510 Rocksville Road

Holland PA 18966

W. M. Goldberger

Superior Graphite Company

R\&D

2175 E. Broad Street

Columbus OH 43209

Allan E. Goldman

U.S. Graphite, Inc.

$907 \mathrm{~W}$. Outer Drive

Oak Ridge TN 37830

Stephen T. Gonczy

Allied Signal Research

P.O. Box 5016

Des Plaines IL 60017

Robert J. Gottschall

U.S. Department of Energy

ER-131, MS:G-236

Washington DC 20585
Earl Graham

Cleveland State University

Dept. of Chemical Engineering

Euclid Avenue at East 24th St.

Cleveland $\mathrm{OH} 44115$

John W. Graham

Astro Met, Inc.

9974 Springfield Pike

Cincinnati $\mathrm{OH} 45215$

G. A. Graves

U. of Dayton Research Institute

300 College Park

Dayton OH 45469-0001

Robert E. Green, Jr.

Johns Hopkins University

Mater. Sci. and Engineering

Baltimore MD 21218

Alex A. Greiner

Plint \& Partners

Oaklands Park

Wokingham Berkshire RG11 2FD

UNITED KINGDOM

Lance Groseclose

Allison Engine Company

P.O. Box 420, MS:W-5

Indianapolis IN 46206

Thomas J. Gross

U.S. Department of Energy

Transportation Technologies

CE-30, Forrestal Building

Washington DC 20585

Mark F. Gruninger

Union Carbide Corporation

Specialty Powder Business

1555 Main Street

Indianapolis IN 46224

Ernst Gugel

Cremer Forschungsinstitut

GmbH\&Co.KG

Oeslauer Strasse 35

D-8633 Roedental 8633

GERMANY 
John P. Gyekenyesi

NASA Lewis Research Center

21000 Brookpark Road, MS:6-1

Cleveland $\mathrm{OH} 44135$

Nabil S. Hakim

Detroit Diesel Corporation

13400 Outer Drive West

Detroit MI 48239

Philip J. Haley

Allison Engine Company

P.O. Box 420, MS:T12A

Indianapolis IN 46206-0420

Judith Hall

Fiber Materials, Inc.

Biddeford Industrial Park

5 Morin Street

Biddeford ME 04005

Y. Hamano

Kyocera Industrial Ceramics

5713 E. Fourth Plain Blvd.

Vancouver WA 98661-6857

Y. Harada

IIT Research Institute

10 West 35th Street

Chicago IL 60616

Norman H. Harris

Hughes Aircraft Company

P.O. Box 800520

Saugus CA 91380-0520

Alan M. Hart

Dow Chemical Company

1776 Building

Midland MI 48674

Pat E. Hart

Battelle Pacific Northwest Labs

Ceramics and Polymers Development

P.O. Box 999

Richland WA 99352
Michael H. Haselkorn

Caterpillar Inc.

Technical Center, Building E

P.O. Box 1875

Peoria IL 61656-1875

Debbie Haught

U.S. Department of Energy

Off. of Transportation Mater.

EE-34, Forrestal Bldg.

Washington DC 20585

N. B. Havewala

Corning Inc.

SP-PR-11

Corning NY 14831

John Haygarth

Teledyne WAA Chang Albany

P.O. Box 460

Albany OR 97321

Norman L. Hecht

U. of Dayton Research Institute

300 College Park

Dayton OH 45469-0172

Peter W. Heitman

Allison Engine Company

P.O. Box 420, MS:W-5

Indianapolis IN 46206-0420

Robert W. Hendricks

VPI \& SU

210 Holden Hall

Blacksburg VA 24061-0237

Thomas P. Herbell

NASA Lewis Research Center

21000 Brookpark Road, MS:49-3

Cleveland $\mathrm{OH} 44135$

Robert L. Hershey

Science Management Corporation 1255 New Hampshire Ave., N.W.

Suite 1033

Washington DC 20036 
Hendrik Heystek

Bureau of Mines

Tuscaloosa Research Center

P.O. Box L

University AL 35486

Robert V. Hillery

GE Aircraft Engines

One Neumann Way, M.D. H85

Cincinnati OH 45215

Arthur Hindman

Instron Corporation

100 Royall Street

Canton MA 02021

Shinichi Hirano

Mazda R\&D of North America

1203 Woodridge Avenue

Ann Arbor MI 48105

Tommy Hiraoka

NGK Locke, Inc.

1000 Town Center

Southfield MI 48075

Fu H. Ho

5645 Soledad Mtn. Road

San Diego, CA 92037-7256

John M. Hobday

U.S. Department of Energy

Morgantown Energy Tech. Ctr.

P.O. Box 880

Morgantown WV 26507

Clarence Hoenig

Lawrence Livermore National Lab

P.O. Box 808, Mail Code L-369

Livermore CA 94550

Thomas Hollstein

Fraunhofer-Institut fur

Werkstoffmechanik

Wohlerstrasse 11

D-79108 Freiburg

GERMANY
Richard Holt

Natl. Research Council Canada

Structures and Materials Lab

Ottawa Ontario K1A OR6

CANADA

Woodie Howe

Coors Technical Ceramics

1100 Commerce Park Drive

Oak Ridge TN 37830

Stephen M. Hsu

NIST

Gaithersburg MD 20899

Hann S. Huang

Argonne National Laboratory

9700 S. Cass Avenue

Argonne IL 60439-4815

Gene Huber

Precision Ferrites \& Ceramics

5576 Corporate Drive

Cypress CA 90630

Fred R. Huettic

Advanced Magnetics Inc.

45 Corey Lane

Mendham NJ 07945

Brian K. Humphrey

Lubrizol Petroleum Chemicals

3000 Town Center, Suite 1340

Southfield MI 48075-1201

Robert M. Humrick

Dylon Ceramic Technologies

3100 Edgehill Road

Cleveland Heights $\mathrm{OH} 44118$

Michael S. Inoue

Kyocera International, Inc.

8611 Balboa Avenue

San Diego CA 92123-1580

Joseph C. Jackson

U.S. Advanced Ceramics Assoc.

1600 Wilson Blvd., Suite 1008

Arlington VA 22209 
Osama Jadaan

U. of Wisconsin-Platteville

1 University Plaza

Platteville WI 53818

Said Jahanmir

NIST

Materials Bldg., Room A-237

Gaithersburg MD 20899

Curtis A. Johnson

General Electric Company

P.O. Box 8

Schenectady NY 12301

Sylvia Johnson

SRI International

333 Ravenswood Avenue

Menlo Park CA 94025

Thomas A. Johnson

Lanxide Corporation

P.O. Box 6077

Newark DE 19714-6077

Walter F. Jones

AFOSR/NA

110 Duncan Ave., Ste. B115

Washington DC 20332-0001

Jill E. Jonkouski

U.S. Department of Energy

9800 S. Cass Avenue

Argonne IL 60439-4899

L. A. Joo

Great Lakes Research Corporation

P.O. Box 1031

Elizabethton TN 37643

Adam Jostsons

Australian Nuclear Science \&

Technology

New Illawarra Road

Lucas Heightss New South Wales AUSTRALIA
Lyle R. Kallenbach

Phillips Petroleum

Mail Drop:123AL

Bartlesville OK 74004

Nick Kamiya

Kyocera Industrial Ceramics Corp. 25 NW

Point Blvd., \#450

Elk Grove Village IL 60007

Roy Kamo

Adiabatics, Inc.

3385 Commerce Park Drive

Columbus IN 47201

Chih-Chun Kao

Industrial Technology Research

Institute

195 Chung-Hsing Road, Sec. 4

Chutung Hsinchu 31015 R.O.C.

TAIWAN

Keith R. Karasek

AlliedSignal Aerospace Company

50 E. Algonquin Road

Des Plaines IL 60017-5016

Robert E. Kassel

Ceradyne, Inc.

3169 Redhill Avenue

Costa Mesa CA 92626

Allan Katz

Wright Laboratory

Metals and Ceramics Division

Wright-Patterson AFB OH 45433

R. Nathan Katz

Worcester Polytechnic Institute

100 Institute Road

Worcester MA 01609

Ted Kawaguchi

Tokai Carbon America, Inc.

375 Park Avenue, Suite 3802

New York NY 10152 
Noritsugu Kawashima

TOSHIBA Corporation

4-1 Ukishima-Cho

Kawasaki-Ku Kawasaki, 210

JAPAN

Lisa Kempfer

Penton Publishing

1100 Superior Avenue

Cleveland $\mathrm{OH}$ 44114-2543

Frederick L. Kennard, III

Delphi Energy \& Engine Mgmt. Systems

Division of General Motors

1300 N. Dort Highway

Flint MI 48556

David O. Kennedy

Lester B. Knight Cast Metals

549 W. Randolph Street

Chicago IL 60661

George Keros

Photon Physics

3175 Penobscot Building

Detroit MI 48226

Thomas Ketcham

Corning, Inc.

SP-DV-1-9

Corning NY 14831

Pramod K. Khandelwal

Allison Engine Company

P.O. Box 420, MS:T10B

Indianapolis IN 46206

Jim R. Kidwell

AlliedSignal Engines

P.O. Box 52180

Phoenix AZ 85072-2180

Shin Kim

The E-Land Group

19-8 ChangJeon-dong

Mapo-gu, Seoul 121-190

KOREA
W. C. King

Mack Truck, Z-41

1999 Pennsylvania Avneue

Hagerstown MD 21740

Carol Kirkpatrick

MSE, Inc.

P.O. Box 3767

Butte MT 59702

Tony Kirn

Caterpillar Inc.

Defense Products Dept., JB7

Peoria IL 61629

James D. Kiser

NASA Lewis Research Center

21000 Brookpark Road, MS:49-3

Cleveland OH 44135

Max Klein

900 24th Street, N.W., Unit G

Washington DC 20037

Richard N. Kleiner

Golden Technologies Company

4545 McIntyre Street

Golden CO 80403

Stanley J. Klima

NASA Lewis Research Center

21000 Brookpark Road, MS:6-1

Cleveland $\mathrm{OH} 44135$

Albert S. Kobayashi

University of Washington

Mechanical Engineering Dept.

Mail Stop:FU10

Seattle WA 98195

Shigeki Kobayashi

Toyota Central Research Labs

Nagakute Aichi, 480-11

JAPAN

Richard A. Kole

Z-Tech Corporation

8 Dow Road

Bow NH 03304 
Joseph A. Kovach

Eaton Corporation

32500 Chardon Road

Willoughby Hills OH 44094

Kenneth A. Kovaly

Technical Insights Inc.

P.O. Box 1304

Fort Lee NJ 07024-9967

Edwin H. Kraft

Kyocera Industrial Ceramics

5713 E. Fourth Plain Boulevard

Vancouver WA 98661

Arthur Kranish

Trends Publishing Inc.

1079 National Press Building

Washington DC 20045

A. S. Krieger

Radiation Science, Inc.

P.O. Box 293

Belmont MA 02178

Pieter Krijgsman

Ceramic Design International Holding

B.V.

P.O. Box 68

Hattem 8050-AB

THE NETHERLANDS

Waltraud M. Kriven

University of Illinois

105 S. Goodwin Avenue

Urbana IL 61801

Edward J. Kubel, Jr.

ASM International

Advanced Materials \& Processes

Materials Park OH 44073

Dave Kupperman

Argonne National Laboratory

9700 S. Cass Avenue

Argonne IL 60439
Oh-Hun Kwon

North Company

SGNICC/NRDC

Goddard Road

Northboro MA 01532-1545

W. J. Lackey

GTRI

Materials Science and Tech. Lab

Atlanta GA 30332

Jai Lala

Tenmat Ltd.

40 Somers Road

Rugby Warwickshire CV22 7DH

ENGLAND

Hari S. Lamba

General Motors Corporation

9301 West 55th Street

LaGrange IL 60525

Richard L. Landingham

Lawrence Livermore National Lab

P.O. Box 808, L-369

Livermore CA 94550

James Lankford

Southwest Research Institute

6220 Culebra Road

San Antonio TX 78228-0510

Stanley B. Lasday

Business News Publishing Co.

1910 Cochran Road, Suite 630

Pittsburgh PA 15220

S. K. Lau

Carborundum Company

Technology Division

P.O. Box 832, B-100

Niagara Falls NY 14302

J. Lawrence Lauderdale

Babcock \& Wilcox

1525 Wilson Blvd., \#100

Arlington VA 22209-2411 
Jean F. LeCostaouec

Textron Specialty Materials

2 Industrial Avenue

Lowell MA 01851

Benson P. Lee

Technology Management, Inc.

4440 Warrensville Rd., Suite A

Cleveland OH 44128

Burtrand I. Lee

Clemson University

Olin Hall

Clemson SC 29634-0907

June-Gunn Lee

KIST

P.O. Box 131, Cheong-Ryang

Seoul $130-650$

KOREA

Stan Levine

NASA Lewis Research Center

21000 Brookpark Road, MS:49-3

Cleveland $\mathrm{OH} 44135$

David Lewis, III

Naval Research Laboratory

Code 6370

Washington DC 20375-5343

Ai-Kang Li

Materials Research Labs., ITRI

195-5 Chung-Hsing Road, Sec. 4

Chutung Hsinchu 31015 R.O.C.

TAIWAN

Robert H. Licht

Norton Company

SGNICC/NRDC

Goddard Road

Northboro MA 01532-1545

E. Lilley

Norton Company

SGNICC/NRDC

Goddard Road

Northboro MA 01532-1545
Chih-Kuang Lin

National Central University

Dept. of Mechanical Engineering

Chung-Li 32054

TAIWAN

Laura J. Lindberg

AlliedSignal Aerospace Company

Garrett Fluid Systems Division

P.O. Box 22200

Tempe AZ 85284-2200

Hans A. Lindner

Cremer Forschungsinstitut

GmbH\&Co.KG

Oeslauer Strasse 35

D-8633 Rodental 8866

GERMANY

Ronald E. Loehman

Sandia National Laboratories

Chemistry \& Ceramics Dept. 1840

P.O. Box 5800

Albuquerque NM 87185

Bill Long

Babcock \& Wilcox

P.O. Box 11165

Lynchburg VA 24506

L. A. Lott

EG\&G Idaho, Inc.

Idaho National Engineering Lab

P.O. Box 1625

Idaho Falls ID 83415-2209

Raouf O. Loutfy

MER Corporation

7960 S. Kolb Road

Tucson AZ 85706

Lydia Luckevich

Ortech International

2395 Speakman Drive

Mississauga Ontario L5K 1B3

CANADA 
James W. MacBeth

Carborundum Company

Structural Ceramics Division

P.O. Box 1054

Niagara Falls NY 14302

George Maczura

Aluminum Company of America

3450 Park Lane Drive

Pittsburgh PA 15275-1119

David Maginnis

Tinker AFB

OC-ALC/LIIRE

Tinker AFB OK 73145-5989

Frank Maginnis

Aspen Research, Inc.

220 Industrial Boulevard

Moore OK 73160

Tai-il Mah

Universal Energy Systems, Inc.

4401 Dayton-Xenia Road

Dayton OH 45432

Kenneth M. Maillar

Barbour Stockwell Company

83 Linskey Way

Cambridge MA 02142

S. G. Malghan

NIST

I-270 \& Clopper Road

Gaithersburg MD 20899

Lars Malmrup

United Turbine AB

Box 13027

Malmo S-200 44

SWEDEN

John Mangels

Ceradyne, Inc.

3169 Redhill Avenue

Costa Mesa CA 92626
Murli Manghnani

University of Hawaii

2525 Correa Road

Honolulu HI 96822

Russell V. Mann

Matec Applied Sciences, Inc.

75 South Street

Hopkinton MA 01748

William R. Manning

Champion Aviation Products Div

P.O. Box 686

Liberty SC 29657

Ken Marnoch

Amercom, Inc.

8928 Fullbright Avenue

Chatsworth CA 91311

Robert A. Marra

Aluminum Company of America

Alcoa Technical Center

Alcoa Center PA 15069

Steve C. Martin

Advanced Refractory Technologies

699 Hertel Avenue

Buffalo NY 14207

Kelly J. Mather

William International Corp.

2280 W. Maple Road

Walled Lake MI 48088

James P. Mathers

3M Company

3M Center, Bldg. 201-3N-06

St. Paul MN 55144

Ron Mayville

Arthur D. Little, Inc.

15-163 Acorn Park

Cambridge MA 02140

F. N. Mazadarany

General Electric Company

Bldg. K-1, Room MB-159

P.O. Box 8

Schenectady NY 12301 
James W. McCauley

Alfred University

Binns-Merrill Hall

Alfred NY 14802

Colin F. McDonald

McDonald Thermal Engineering

1730 Castellana Road

La Jolla CA 92037

B. J. McEntire

Norton Company

10 Airport Park Road

East Granby CT 06026

Chuck McFadden

Coors Ceramics Company

600 9th Street

Golden CO 80401

Thomas D. McGee

Iowa State University

110 Engineering Annex

Ames IA 50011

James McLaughlin

Sundstrand Power Systems

4400 Ruffin Road

P.O. Box 85757

San Diego CA 92186-5757

Matt McMonigle

U.S. Department of Energy

Improved Energy Productivity

CE-231, Forrestal Building

Washington DC 20585

J. C. McVickers

AlliedSignal Engines

P.O. Box 52180, MS:9317-2

Phoenix AZ 85072-2180

D. B. Meadowcroft

"Jura," The Ridgeway

Oxshott

Leatherhead Surrey KT22 OLG

UNITED KINGDOM
Joseph J. Meindl

Reynolds International, Inc.

6603 W. Broad Street

P.O. Box 27002

Richmond VA 23261-7003

Michael D. Meiser

AlliedSignal, Inc.

Ceramic Components

P.O. Box 2960, MS:T21

Torrance CA 90509-2960

George Messenger

National Research Council of Canada

Building M-7

Ottawa Ontario K1A OR6

CANADA

Arthur G. Metcalfe

Arthur G. Metcalfe \& Assoc.

2108 East 24th Street

National City CA 91950

R. Metselaar

Eindhoven University

P.O. Box 513

Endhoven $5600 \mathrm{MB}$

THE NETHERLANDS

David J. Michael

Harbison-Walker Refractories

P.O. Box 98037

Pittsburgh PA 15227

Ken Michaels

Chrysler Motors Corporation

P.O. Box 1118, CIMS:418-17-09

Detroit MI 48288

Bernd Michel

Institute of Mechanics

P.O. Box 408

D-9010 Chemnitz

GERMANY 
D. E. Miles

Commission of the European

Community

rue de la Loi 200

B-1049 Brussels

BELGIUM

Carl E. Miller

AC Rochester

1300 N. Dort Highway, MS:32-31

Flint MI 48556

Charles W. Miller, Jr.

Centorr Furnaces/Vacuum

Industries

542 Amherst Street

Nashua NH 03063

R. Minimmi

Enichem America

2000 Cornwall Road

Monmouth Junction NJ 08852

Michele V. Mitchell

AlliedSignal, Inc.

Ceramic Components

P.O. Box 2960, MS:T21

Torrance CA 90509-2960

Howard Mizuhara

WESGO

477 Harbor Boulevard

Belmont CA 94002

Helen Moeller

Babcock \& Wilcox

P.O. Box 11165

Lynchburg VA 24506-1165

Francois R. Mollard

Concurrent Technologies Corp.

1450 Scalp Avenue

Johnstown PA 15904-3374

Phil Mooney

Panametrics

221 Crescent Street

Waltham MA 02254
Geoffrey P. Morris

3M Company

3M Traffic Control Materials

Bldg. 209-BW-10, 3M Center

St. Paul MN 55144-1000

Jay A. Morrison

Rolls-Royce, Inc.

2849 Paces Ferry Rd., Suite 450

Atlanta GA 30339-3769

Joel P. Moskowitz

Ceradyne, Inc.

3169 Redhill Avenue

Costa Mesa CA 92626

Brij Moudgil

University of Florida

Material Science \& Engineering

Gainesville FL 32611

Christoph J. Mueller

Sprechsaal Publishing Group

P.O. Box 2962, Mauer 2

D-8630 Coburg

GERMANY

Thomas W. Mullan

Vapor Technologies Inc.

345 Route 17 South

Upper Saddle River NJ 07458

Theresa A. Mursick-Meyer

Norton Company

SGNICC/NRDC

Goddard Road

Northboro MA 01532-1545

M. K. Murthy

MkM Consultants International

10 Avoca Avenue, Unit 1906

Toronto Onntario M4T 2B7

CANADA

David L. Mustoe

Custom Technical Ceramics

8041 W I-70 Service Rd. Unit 6

Arvada CO 80002 
Curtis V. Nakaishi

U.S. Department of Energy

Morgantown Energy Tech. Ctr.

P.O. Box 880

Morgantown WV 26507-0880

Yoshio Nakamura

Faicera Research Institute

3-11-12 Misono

Sagamihara, Tokyo

JAPAN

K. S. Narasimhan

Hoeganaes Corporation

River Road

Riverton NJ 08077

Robert Naum

Applied Resources, Inc.

P.O. Box 241

Pittsford NY 14534

Malcolm Naylor

Cummins Engine Company, Inc.

P.O. Box 3005, Mail Code 50183

Columbus IN 47202-3005

Fred A. Nichols

Argonne National Laboratory

9700 S. Cass Avenue

Argonne IL 60439

H. Nickel

Forschungszentrum Juelich (KFA)

Postfach 1913

D-52425 Juelich

GERMANY

Dale E. Niesz

Rutgers University

Center for Ceramic Research

P.O. Box 909

Piscataway NJ 08855-0909

Paul W. Niskanen

Lanxide Corporation

P.O. Box 6077

Newark DE 19714-6077
David M. Nissley

United Technologies Corporation

Pratt \& Whitney Aircraft

400 Main Street, MS:163-10

East Hartford CT 06108

Daniel Oblas

50 Meadowbrook Drive

Bedford MA 01730

Don Ohanehi

Magnetic Bearings, Inc.

1908 Sussex Road

Blacksburg VA 24060

Hitoshi Ohmori

ELID Team

Itabashi Branch

1-7 13 Kaga Itabashi

Tokyo 173

JAPAN

Robert Orenstein

General Electric Company

55-112, River Road

Schenectady NY 12345

Richard Palicka

Cercom, Inc.

1960 Watson Way

Vista CA 92083

Joseph N. Panzarino

379 Howard Street

P. O. Box 652

Northboro MA 01532-1545

Pellegrino Papa

Corning Inc.

MP-WX-02-1

Corning NY 14831

Terry Paquet

Boride Products Inc.

2879 Aero Park Drive

Traverse City MI 49684 
E. Beth Pardue

MPC

8297 Williams Ferry Road

Lenior City TN 37771

Soon C. Park

3M Company

Building 142-4N-02

P.O. Box 2963

St. Paul MN 55144

Vijay M. Parthasarathy

Caterpillar/Solar Turbines

2200 Pacific Highway

P.O. Box 85376

San Diego CA 92186-5376

Harmut Paschke

Schott Glaswerke

Christoph-Dorner-Strasse 29

D-8300 Landshut

GERMANY

James W. Patten

Cummins Engine Company, Inc.

P.O. Box 3005, Mail Code 50183

Columbus IN 47202-3005

Robert A. Penty

Penty \& Associates

38 Oakdale Drive

Rocester NY 14618

Robert W. Pepper

Textron Specialty Materials

2 Industrial Avenue

Lowell MA 01851

Peter Perdue

Detroit Diesel Corporation

13400 Outer Drive West,

Speed Code L-04

Detroit MI 48239-4001

John J. Petrovic

Los Alamos National Laboratory

Group MST-4, MS:G771

Los Alamos NM 87545
Frederick S. Pettit

University of Pittsburgh

Pittsburgh PA 15261

Richard C. Phoenix

Ohmtek, Inc.

2160 Liberty Drive

Niagara Falls NY 14302

Bruce J. Pletka

Michigan Technological Univ.

Metallurgical \& Materials Engr.

Houghton MI 49931

John P. Pollinger

AlliedSignal, Inc.

Ceramic Components

P.O. Box 2960, MS:T21

Torrance CA 90509-2960

P. Popper

High Tech Ceramics Int. Journal 22

Pembroke Drive - Westlands

Newcastle-under-Lyme

Staffs ST5 2JN

ENGLAND

F. Porz

Universitat Karlsruhe

Institut fur Keramik Im

Maschinendau

Postfach 6980

D-76128 Karlsruhe

GERMANY

Harry L. Potma

Royal Netherlands Embassy

Science and Technology

4200 Linnean Avenue, N.W.

Washington DC 20008

Bob R. Powell

General Motors Corporation

Metallurgy Department

Box 9055

Warren MI 48090-9055 
Stephen C. Pred

Biesterfeld U.S., Inc.

500 Fifth Avenue

New York NY 10110

Karl M. Prewo

United Technologies Res. Ctr.

411 Silver Lane, MS:24

East Hartford CT 06108

Vimal K. Pujari

Norton Company

SGNICC/NRDC

Goddard Road

Northboro MA 01532-1545

Fred Quan

Corning Inc.

Sullivan Park, FR-02-08

Corning NY 14831

George Quinn

NIST

Ceramics Division, Bldg. 223

Gaithersburg MD 20899

Ramas V. Raman

Ceracon, Inc.

1101 N. Market Blvd., Suite 9

Sacramento CA 95834

Charles F. Rapp

Owens Corning Fiberglass

2790 Columbus Road

Granville OH 43023-1200

Dennis W. Readey

Colorado School of Mines

Metallurgy and Materials Engr.

Golden CO 80401

Wilfred J. Rebello

PAR Enterprises, Inc.

12601 Clifton Hunt Lane

Clifton VA 22024

Harold Rechter

Chicago Fire Brick Company

7531 S. Ashland Avenue

Chicago IL 60620
Robert R. Reeber

U.S. Army Research Office

P.O. Box 12211

Research Triangle Park NC 27709-2211

K. L. Reifsnider

VPI \& SU

Engineering Science and Mechanics

Blacksburg VA 24061

Paul E. Rempes

McDonnell Douglass Aircraft Co.

P.O. Box 516, Mail Code:0642263

St. Louis MO 63166-0516

Gopal S. Revankar

John Deere Company

3300 River Drive

Moline IL 61265

K. Y. Rhee

Rutgers University

P.O. Box 909

Piscataway NJ 08854

James Rhodes

Advanced Composite Materials

1525 S. Buncombe Road

Greer SC 29651

Roy W. Rice

W. R. Grace and Company

7379 Route 32

Columbia MD 21044

David W. Richerson

2093 E. Delmont Drive

Salt Lake City UT 84117

Tomas Richter

J. H. France Refractories

1944 Clarence Road

Snow Shoe PA 16874 
Michel Rigaud

Ecole Polytechnique

Campus Universite De Montreal

P.O. Box 6079, Station A

Montreal, P.Q. Quebec H3C 3A7

CANADA

John E. Ritter

University of Massachusetts

Mechanical Engineering Department

Amherst MA 01003

W. Eric Roberts

Advanced Ceramic Technology

990 "F" Enterprise Street

Orange CA 92667

Y. G. Roman

TNO TPD Keramick

P.O. Box 595

Einhoven 5600 AN

HOLLAND

Michael Rossetti

Arthur D. Little, Inc.

15 Acorn Park

Cambridge MA 01240

Barry Rossing

Lanxide Corporation

P.O. Box 6077

Newark DE 19714-6077

Steven L. Rotz

Lubrizol Corporation

29400 Lakeland Boulevard

Wickliffe OH 44092

Robert Ruh

Wright Laboratory

WL/MLLM

Wright-Patterson AFB OH 45433

Robert J. Russell

Riverdale Consulting, Inc.

24 Micah Hamlin Road

Centerville MA 02632-2107
Jon A. Salem

NASA Lewis Research Center

21000 Brookpark Road

Cleveland $\mathrm{OH} 44135$

W. A. Sanders

NASA Lewis Research Center

21000 Brookpark Road, MS:49-3

Cleveland $\mathrm{OH} 44135$

J. Sankar

North Carolina A\&T State Univ. Dept. of Mechanical Engineering Greensboro NC 27406

Yasushi Sato

NGK Spark Plugs (U.S.A.), Inc.

1200 Business Center Dr., $\# 300$

Mt. Prospect IL 60056

Maxine L. Savitz

AlliedSignal, Inc.

Ceramic Components

P.O. Box 2960, MS:T21

Torrance CA 90509-2960

Ashok Saxena

GTRI

Materials Engineering

Atlanta GA 30332-0245

David W. Scanlon

Instron Corporation

100 Royall Street

Canton MA 02021

Charles A. Schacht

Schacht Consulting Services

12 Holland Road

Pittsburgh PA 15235

Robert E. Schafrik

Natl Materials Advisory Board

2101 Constitution Ave., N.W.

Washington DC 20418

James Schienle

AlliedSignal Engines

P.O. Box 52180, MS:1302-2P

Phoenix AZ 85072-2180 
Gary Schnittgrund

PyroPacific Processes

16401 Knollwood Drive

Granada Hills, CA 91344

Mark Schomp

Lonza, Inc.

17-17 Route 208

Fair Lann NJ 07410

Joop Schoonman

Delft University of Technology

P.O. Box 5045

2600 GA Delft

THE NETHERLANDS

Robert B. Schulz

U.S. Department of Energy

Office of Transportation Mater.

CE-34, Forrestal Building

Washington DC 20585

Murray A. Schwartz

Materials Technology Consulting

30 Orchard Way, North

Potomac MD 20854

Peter Schwarzkopf

SRI International

333 Ravenswood Avenue

Menlo Park CA 94025

William T. Schwessinger

Multi-Arc Scientific Coatings

1064 Chicago Road

Troy MI 48083-4297

W. D. Scott

University of Washington

Materials Science Department

Mail Stop:FB10

Seattle WA 98195

Nancy Scoville

Thermo Electron Technologies

P.O. Box 9046

Waltham MA 02254-9046
Thomas M. Sebestyen

U.S. Department of Energy

Advanced Propulsion Division

CE-322, Forrestal Building

Washington DC 20585

Brian Seegmiller

Coors Ceramics Company

600 9th Street

Golden CO 80401

T. B. Selover

AICRE/DIPPR

3575 Traver Road

Shaker Heights OH 44122

Charles E. Semler

Semler Materials Services

4160 Mumford Court

Columbus $\mathrm{OH} 43220$

Thomas Service

Service Engineering Laboratory

324 Wells Street

Greenfield MA 01301

Kish Seth

Ethyl Corporation

P.O. Box 341

Baton Rouge LA 70821

William J. Shack

Argonne National Laboratory

9700 S. Cass Avenue, Bldg. 212

Argonne IL 60439

Peter T.B. Shaffer

Shaffer Associates

3225 Chimney Cove Drive

Cumming GA 30131

Richard K. Shaltens

NASA Lewis Research Center

21000 Brookpark Road, MS:302-2

Cleveland $\mathrm{OH} 44135$

Robert S. Shane

1904 NW 22nd Street

Stuart FL 34994-9270 
Ravi Shankar

Chromalloy

Research and Technology

Blaisdell Road

Orangeburg NY 10962

Terence Sheehan

Alpex Wheel Company

727 Berkley Street

New Milford NJ 07646

Dinesh K. Shetty

University of Utah

Materials Science and Engineering

Salt Lake City UT 84112

Masahide Shimizu

New Ceramics Association

Shirasagi 2-13-1-208, Nakano-ku

Tokyo, 165

JAPAN

Thomas Shreves

American Ceramic Society, Inc.

735 Ceramic Place

Westerville OH 43081-8720

Jack D. Sibold

Coors Ceramics Company

4545 McIntyre Street

Golden CO 80403

Johann Siebels

Volkswagen AG

Werkstofftechnologie

Postfach 3180

Wolfsburg 1

GERMANY

George H. Siegel

Point North Associates, Inc.

P.O. Box 907

Madison NJ 07940

Richard Silberglitt

FM Technologies, Inc.

10529-B Braddock Road

Fairfax VA 22032
Mary Silverberg

Norton Company

SGNICC/NRDC

Goddard Road

Northboro MA 01532-1545

Gurpreet Singh

Department of the Navy

Code 56X31

Washington DC 20362-5101

Maurice J. Sinnott

University of Michigan

5106 IST Building

Ann Arbor MI 48109-2099

John Skildum

3M Company

3M Center

Building 224-2S-25

St. Paul MN 55144

Richard H. Smoak

Smoak \& Associates

3554 Hollyslope Road

Altadena CA 91001-3923

Jay R. Smyth

AlliedSignal Engines

111 S. 34th Street, MS:503-412

Phoenix AZ 85034

Rafal A. Sobotowski

British Petroleum Company

Technical Center, Broadway

3092 Broadway Avenue

Cleveland $\mathrm{OH} 44115$

S. Somiya

Nishi Tokyo University

3-7-19 Seijo, Setagaya

Tokyo, 157

JAPAN

Boyd W. Sorenson

DuPont Lanxide Composites

1300 Marrows Road

Newark DE 19711 
Charles A. Sorrell

U.S. Department of Energy

Advanced Industrial Concepts

CE-232, Forrestal Building

Washington DC 20585

C. Spencer

EA Technology

Capenhurst Chester CH1 6ES

UNITED KINGDOM

Allen Spizzo

Hercules Inc.

Hercules Plaza

Wilmington DE 19894

Richard M. Spriggs

Alfred University

Ctr. for Advanced Ceramic Tech.

Alfred NY 14802

Charles Spuckler

NASA Lewis Research Center

21000 Brookpark Road, MS:5-11

Cleveland OH 44135-3191

Gordon L. Starr

Cummins Engine Company, Inc.

P.O. Box 3005, Mail Code:50182

Columbus IN 47202-3005

Tom Stillwagon

AlliedSignal, Inc.

Ceramic Components

P.O. Box 2960, MS:T21

Torrance CA 90509-2960

H. M. Stoller

TPL Inc.

3754 Hawkins, N.E.

Albuquerque NM 87109

Paul D. Stone

Dow Chemical USA

1776 "Eye" Street, N.W., \#575

Washington DC 20006
F. W. Stringer

Aero \& Industrial Technology

P.O. Box 46, Wood Top

Burnley Lancashire BB11 4BX

UNITED KINGDOM

Thomas N. Strom

NASA Lewis Research Center

21000 Brookpark Road, MS:86-6

Cleveland $\mathrm{OH} 44135$

M. F. Stroosnijder

Institute for Advanced Materials

Joint Research Centre

21020 Ispra (VA)

ITALY

Karsten Styhr

30604 Ganado Drive

Rancho Palos Verdes CA 90274

T. S. Sudarshan

Materials Modification, Inc.

2929-P1 Eskridge Center

Fairfax VA 22031

M. J. Sundaresan

University of Miami

P.O. Box 248294

Coral Gables FL 33124

Patrick L. Sutton

U.S. Department of Energy

Office of Propulsion Systems

CE-322, Forrestal Building

Washington DC 20585

Willard H. Sutton

United Technologies Corporation

Silver Lane, MS:24

East Hartford CT 06108

Robert E. Swanson

Metalworking Technology, Inc.

1450 Scalp Avenue

Johnstown PA 15904 
Yo Tajima

NGK Spark Plug Company

2808 Iwasaki

Komaki-shi Aichi-ken, 485

JAPAN

Fred Teeter

5 Tralee Terrace

East Amherst NY 14051

Victor J. Tennery

113 Newell Lane

Oak Ridge TN 37830

Monika O. Ten Eyck

Carborundum Microelectronics

P.O. Box 2467

Niagara Falls NY 14302-2467

David F. Thompson

Corning Glass Works

SP-DV-02-1

Corning NY 14831

T. Y. Tien

University of Michigan

Materials Science \& Engineering

Dow Building

Ann Arbor MI 48103

D. M. Tracey

Norton Company

SGNICC/NRDC

Goddard Road

Northboro MA 01532-1545

Marc Tricard

Norton Company, WGTC

1 New Bond Street, MS-413-201

Worcester MA 01615-0008

L. J. Trostel, Jr.

Box 199

Princeton MA 01541

W. T. Tucker

General Electric Company

P.O. Box 8, Bldg. K1-4C35

Schenectady NY 12301
Masanori Ueki

Nippon Steel Corporation

1618 Ida

Nakahara-Ku Kawasaki, 211

JAPAN

Filippo M. Ugolini

ATA Studio

Via Degli Scipioni, 268A

ROMA, 00192

ITALY

Donald L. Vaccari

Allison Gas Turbines

P.O. Box 420, Speed Code S49

Indianapolis IN 46206-0420

Carl F. Van Conant

Boride Products, Inc.

2879 Aero Park Drive

Traverse City MI 49684

John F. Vander Louw

3M Company

3M Center, Bldg. 60-1N-01

Saint Paul MN 55144

Marcel H. Van De Voorde

Commission of the European

Community

P.O. Box 2

1755 ZG Petten

THE NETHERLANDS

O. Van Der Biest

Katholieke Universiteit Leuven

Dept. Metaalkunde en Toegepaste

de Croylaan 2

B-3030 Leuven

BELGIUM

Michael Vannier

Washington University,

St. Louis

510 S. Kings Highway

St. Louis MO 63110 
Stan Venkatesan

Southern Coke \& Coal Corp.

P.O. Box 52383

Knoxville TN 37950

V. Venkateswaran

Carborundum Company

Niagara Falls R\&D Center

P.O. Box 832

Niagara Falls NY 14302

Ted Vojnovich

U.S. Department of Energy

Office of Energy Research, 3F077P

Washington DC 20585

John D. Volt

E.I. Dupont de Nemours \& Co.

P.O. Box 80262

Wilmington DE 19880

John B. Wachtman

Rutgers University

P.O. Box 909

Piscataway NJ 08855

Shigetaka Wada

Toyota Central Research Labs

Nagakute Aichi, 480-11

JAPAN

Janet Wade

AlliedSignal Engines

P.O. Box 52180, MS:1303-2

Phoenix AZ 85072-2180

Richard L. Wagner

Ceramic Technologies, Inc.

537 Turtle Creek South Dr.

Indianapolis IN 46227

J. Bruce Wagner, Jr.

Arizona State University

Center for Solid State Science

Tempe AZ 85287-1704

Daniel J. Wahlen

Kohler, Co.

444 Highland Drive

Kohler WI 53044
Ingrid Wahlgren

Royal Institute of Technology

Studsvik Library

S-611 82 Nykoping

SWEDEN

Ron H. Walecki

AlliedSignal, Inc.

Ceramic Components

P.O. Box 2960, MS:T21

Torrance CA 90509-2960

Michael S. Walsh

Vapor Technologies Inc.

6300 Gunpark Drive

Boulder CO 80301

Chien-Min Wang

Industrial Technology Research

Institute

195 Chung-Hsing Road, Sec. 4

Chutung Hsinchu 31015 R.O.C.

TAIWAN

Robert M. Washburn

ASMT

11203 Colima Road

Whittier CA 90604

Kevin Webber

Toyota Technical Center, U.S.A.

1410 Woodridge, RR7

Ann Arbor MI 48105

Karen E. Weber

Detroit Diesel Corporation

13400 Outer Drive West

Detroit MI 48239-4001

James K. Weddell

Du Pont Lanxide Composites Inc.

P.O. Box 6100

Newark DE 19714-6100

R. W. Weeks

Argonne National Laboratory

MCT-212

9700 S. Cass Avenue

Argonne IL 60439 
Ludwig Weiler

ASEA Brown Boveri AG

Eppelheimer Str. 82

D-6900 Heidelberg

GERMANY

James Wessel

127 Westview Lane

Oak Ridge TN 37830

Robert D. West

Therm Advanced Ceramics

P.O. Box 220

Ithaca NY 14851

Thomas J. Whalen

1845 Cypress Pointe Court

Ann Arbor MI 48108

Ian A. White

Hoeganaes Corporation

River Road

Riverton NJ 08077

Sheldon M. Wiederhorn

NIST

Building 223, Room A329

Gaithersburg MD 20899

John F. Wight

Alfred University

McMahon Building

Alfred NY 14802

D. S. Wilkinson

McMaster University

1280 Main Street, West

Hamilton Ontario L8S 4L7

CANADA

James C. Williams

General Electric Company

Engineering Materials Tech.

One Neumann Way, Mail Drop:H85

Cincinnati OH 45215-6301

Steve J. Williams

RCG Hagler Bailly, Inc.

1530 Wilson Blvd., Suite 900

Arlington VA 22209-2406
Thomas A. Williams

National Renewable Energy Lab

1617 Cole Boulevard

Golden CO 80401

Craig A. Willkens

Norton Company

SGNICC/NRDC

Goddard Road

Northboro MA 01532-1545

Roger R. Wills

Ohio Aerospace Institute (OAI)

22800 Cedar Point Road

Brook Park OH 44142

David Gordon Wilson

Massachusetts Institute of

Technology

77 Massachusetts Ave., Rm 3-455

Cambridge MA 02139

J. M. Wimmer

AlliedSignal Ceramic Components

Department 27000, MS:T21

2525 W. 190th Street

Torrance CA 90509

Matthew F. Winkler

Seaworthy Systems, Inc.

P.O. Box 965

Essex CT 06426

Gerhard Winter

Hermann C. Starck Berlin GmbH

P.O. Box 2540

D-3380 Goslar 3380

GERMANY

Thomas J. Wissing

Eaton Corporation

Engineering and Research Center

P.O. Box 766

Southfield MI 48037

James C. Withers

MER Corporation

7960 S. Kolb Road

Building $F$

Tucson AZ 85706 
Dale E. Wittmer

Southern Illinois University

Mechanical Engineering Dept.

Carbondale IL 62901

Warren W. Wolf

Owens Corning Fiberglass

2790 Columbus Road, Route 16

Granville $\mathrm{OH} 43023$

Egon E. Wolff

Caterpillar Inc.

Technical Center

P.O. Box 1875

Peoria IL 61656-1875

George W. Wolter

Howmet Turbine Components Corp.

Technical Center

699 Benston Road

Whitehall MI 49461

Wayne L. Worrell

University of Pennsylvania

3231 Walnut Street

Philadelphia PA 19104

John F. Wosinski

Corning Inc.

ME-2 E-5 H8

Corning NY 14830

Ruth Wroe

ERDC

Capenhurst Chester CH1 6ES

ENGLAND

Bernard J. Wrona

Advanced Composite Materials

1525 S. Buncombe Road

Greer SC 29651

Carl C. M. Wu

Naval Research Laboratory

Ceramic Branch, Code 6373

Washington DC 20375
David C. Wu

AlliedSignal Engines

P.O. Box 52181, MS:301-227

Phoenix AZ 85072-2181

John C. Wurst

U. of Dayton Research Institute

300 College Park

Dayton OH 45469-0101

Neil Wyant

ARCH Development Corp.

9700 S. Cass Avenue, Bldg. 202

Argonne IL 60439

Roy Yamamoto

Texaco Inc.

P.O. Box 509

Beacon NY 12508-0509

John Yamanis

AlliedSignal Aerospace Company

P.O. Box 1021

Morristown NJ 07962-1021

Harry C. Yeh

AlliedSignal, Inc.

Ceramic Components

P.O. Box 2960, MS:T21

Torrance CA 90509-2960

Hiroshi Yokoyama

Hitachi Research Lab

4026 Kuji-Cho

Hitachi-shi Ibaraki 319-12

JAPAN

Thomas M. Yonushonis

Cummins Engine Company, Inc.

P.O. Box 3005, Mail Code 50183

Columbus IN 47202-3005

Jong Yung

Sundstrand Aviation Operations

4747 Harrison Avenue

Rockford IL 61125

C. S. Yust

106 Newcrest Lane

Oak Ridge TN 37830 
A. L. Zadoks

Caterpillar Inc.

Technical Center, Building L

P.O. Box 1875

Peoria IL 61656-1875

Avi Zangvil

University of Illinois

104 S. Goodwin Avenue

Urbana IL 61801

Charles H. Zenuk

Transtech

6662 E. Paseo San Andres

Tucson AZ 85710-2106

Carl Zweben

General Electric Company

P. O Box 8555, VFSC/V4019

Philadelphia PA 19101

Department of Energy

Oak Ridge Operations Office

Asst. Manager for Energy

Research and Development

P.O. Box 2001

Oak Ridge, TN 37871-8600

Department of Energy

Office of Scientific and

Technical Information

Office of Information Services

P.O. Box 62

Oak Ridge, TN 37831 ? 